\title{
A STUDY ON THE DIFFERENTIAL THERMAL ANALYSIS OF CLAYS AND CLAY MINERALS
}


Dit proefschrift met stellingen van

\section{PEDRO LAURENT ARENS}

landbouwkundig ingenieur, geboren te Malang (Java) de 25ste September 1922, is goedgekeurd door de promotor Dr A. C. Schuffelen, hoogleraar in de Landbouwscheikunde.

De Rector Magnificus der Sandbouwhogesohool,

H. J. C. TENDELOO

Wageningen, 4 Juni 1951 


\title{
A STUDY ON THE DIFFERENTIAL THERMAL ANALYSIS OF CLAYS AND CLAY MINERALS
}

\author{
PROEFSCHRIFT \\ TER VERKRIJGING VAN DE GRAAD VAN \\ DOCTOR IN DE LANDBOUWKUNDE, OP \\ GEZAG VAN DE RECTOR MAGNIFICUS \\ Dr H. J. C. TENDELOO, HOOGLERAAR IN \\ DE SCHEIKUNDE, TE VERDEDIGEN TEGEN \\ DE BEDENKINGEN VAN EEN COMMISSIE \\ UIT DE SENAAT VAN DE LANDBOUW. \\ HOGESCHOOL TE WAGENINGEN OP \\ VRIJDAG 29 JUNI 1951 TE 14.30 UUR
}

DOOR

\section{PEDRO LAURENT ARENS}

DRUK: EXCELSIORS FOTO-OFFSET, - 'S-GRAVENHAGE

\section{Bibliotheek} der

Landbouw Hoogeschool WAGENINGEN 


\section{IX}

$\because \because$ tegenstrijdigheid in opvattingen over de invloed van het ziikstofgehalte van het tabaksblad op de brandduur, kan grotendeels worden vorklaard uit verschillen in fermentatie.

\section{$X$}

De veelvuldige toepassing van repressieve bestrijdingomiddelen voor plantenziekten betekent een gevar voor de ontwikkeling van de plantenhygiëne.

Het tijdelijk onder water zetten van terreinen, die bestemd zijn als zaadbedden voor de tabakscultuur, kan worden beschouwd als een plantenhygiënische matregel ter verkrijging van bibit vrij van slijmziekte.

\section{XII}

Voor de bepaling van het warmtegeleidingsvermogen van grond, verdienen niet-stationnaire methoden de voorkeur boven statische.

\section{XIIT}

De verklaring van het heterosigverschijnsel door een gunstige genencombinatie is onvolledig.

\section{XIV}

De gelegenheid tot het houden van publieke promoties aan de Iandbouwhogeschool dient verruimd te worden in verband met het veelzijdig karakter van de landbouwkunde. 
IX

- tegenstrijdigheid in opvattingen over de invloed van het $\therefore$ ikstofgehalte van het tabaksblad op de brandduur, kan grotendevls worden verklaard uit verschillen in fermentatie.

$X$

De veelvuldige toepassing van repressieve bestrijdingsmiddelen voor plantenziekten betekent een gevarr voor de ontwikkeling van de plantenhygiëne.

$\mathrm{XI}$

Het tijdelijk onder water zetten van terreinen, die restemd zijn als zaadbedden voor de tabaksoultuur, kan worden beschouwd als een plantenhygiënische matregel ter verkrijging van bibit vrij van slijmziekte.

XII

Voor de bepaling van het warmtegeleidingsvermogen van grond, verdienen niet-stationnaire methoden de voorkeur boven statische.

XIII

De verklaring van het heterosiavers hijnsel door een gunstige genencombinatie is onvolledig.

XIV

De gelegenheid tot het houden van publieke promoties aan de Landbouwhogeschool dient verruimd te worden in verband met het veelzijdig karakter van de landbouwkunde. 


\section{STELLINGEN}

$I$

De dehydratatie van kleimineralen kan beschreven worden als een monomoleculaire reactie.

II

Het vobrkomen van amorphe colloiden in de bodem is onwaarschijn$11 j k$.

III

De Friese knipgronden mogen worden beschreven als verouderde solonetz gronden.

IV

De bruine bandjes in de ondergrond van pleistocene zandgronden zijn veroorzaakt door schifting van ijzervèrbindingen.

$\mathrm{V}$

De methyleerbaarheid van montmorilloniet is geen bewijs voor de juistheid van de opvattingen van EDEIMAN en FAVEJEE omtrent de kriatalstructuur van dat kleimineraal.

$\cdot$ VI

Bif het verbeteren. van de plantenproductie op $\mathrm{K}$-fixerende gronden zijn structuurverbetering en plaatselijke bemesting de aan-. gewezen maatregelen.

VII

De toevoeging van jodium aan leidingwater, ter bestrijding van struma, betekent niet het meest efficient gebruik van deze stof.

VIII

Het is onjuist de waterhuishouding van bodemprofielen te beschouwen 108 van het microtopograftech verband waarin die profielen roorkomen. 


\section{VOORWOORD (PREFACE)}

Bif de definitieve beelndiging.van mijn studie aan de Landbouwhogeschool gaat mifn oprechte dank uit naar allen die tot mijn wetenschappelifke vorming hebben bifgedragen, of die mij anderazing hebben bijgestaan.

In het bijzonder richt ik mij tot 0 ; Hooggeleerde SCHUFFEIEN, hooggeachte promotor. Op Uw inftiatief werd het onderhavig onderzoek ter hand genomen. Aan $\mathrm{Ww}$ voortdurende intense belangstelling, maar meer nog aan Uw scherpe critische zin bij het stellen der problemen, dank ik de voltooling ervan. Ik dank $U$ voor het zeer vele, dat $i k$ van $U$ tijdens mijn assistentschap heb mogen leren. Niet alleen door $U$ w colleges, maar eveneens door $U$ w persioon heb ik een vorming van blifvende warde aan $U$ te danken. Ik vertrouw ook in de toekomst nog menigmaal Uw raad in te mogen winnen. Ook Uw voorganger en ons beider leermeester Prof. HUDIG, betuig ik gaarne mijn dank voor zijn onvergetelijke colleges en excursies.

Hooggeleerde EDELMAN, mede door Uw veelzijdige en bezielende werkzaamheld is het kleimineralogisch onderzock te Wageningen tot bloei gekomen. Uw grote belangstelling voor de resultaten van mijn werk is voor mij een bewijs, dat het niet zonder betekenis is voor de kleimineralogie. Ik dank $U$ voor de vele animerende discussies, wardoor steeds weer nieuwe vergezichten voor mij geopend werden vanuit het grote raam van de bodemkunde. De wijze, warop gij de grote lifn weet vast te houden bij alle detallwerk, heb ik steeds als voorbeeld voor ogen.

Hooggeleerde COOLHAAS, hoewel ik niet tot Uw leerlingen in stricte zin behoor, reken ik het tot een voorrecht enige tijd in $U$ w gezelschap te hebben vertoefd. Het anschouwelijk onderwijo in tropische en subtropische plantenteelt, toen genoten, zal steeds als een van de moolste tijden van mijn studie in mijn herinnering blifven leven. Ik hoop in de toekomet nog viakk een beroep te mogen doen op Uw rijke ervaring. Ook UW voorganger, mijn leermeester Prof, van der STOK ben ik ten zeerste dankbaar voor het bij hem geleerde.

Hooggeleerde TENDELOO, voor de digcussies over reactiesnelheld en de toepassing darrvan op de thermische analyse, ben ik $\dot{U}$ ten zeerste erkentelifk.

Hooggeleerde van UVEN, Ow raadgevingen en Uw hulp bif sommige gedeelten vari dit werk, waren voor mif van hoge waarde. 
U, Hooggeleerde LENIGER, dank ik voor de mij geboden gelegenheid om me te verdiepen in de keramiache klei-literatuur.

Hooggeleerde HONING $t$, Hooggeleerde PRAKKEN, Uw lessen in erfelijkheidsleer blijven voor mij van grote warde.

Hooggeleerde QUANJER, ik zeg U dank voor de wijze, waarop gij mij hebt vertrouwd gemaakt met de begingelen der phytopathologie, in de tuin van Uw evacuatiedomicilie te Veenendar. Uw bezlelende en fijnzinnige colleges heb ik ten zeerste op prifs gesteld.

To you, Profegsor DON KIRKHAM, I am greatly indebted for your kindness to watch over the English text. I appreciated very much your interest in my work and your valuable criticism.

Zeergeleerde van der MAREI, onvermoelbaar werker, ik dank je voor je ruimschoots verleende medewerking en voor de wijze, warop je nieuwe problemen stelde aan de thermische analyse. Ik reken op een blijvende samenwerking, niet alleen in het kleionderzoek.

Ook aan jullie, zeergeleerde D.A. de VRIES en Ir C.T. de Wit, ben ik veel dank verschuldigd voor je critiek en de prettige samenwerking.

Aan Professor WIBAUT zeg ik dank voor de gelegenheid, mij geboden, om enige organische kleiderivaten te vervaardigen. Voor de verleende hulp ben ik veel verschuldigd an mijn oudcollegae Dr L.W.F.KAMPSCHMIDT, Dr H.G.P.van der VOORT en Drs H. BOON.

A vous, Mademoiselle CAILIERE et Professeur HENIN, ma plus sincère reconnaissance pour votre amabilité, éprouvé pendant mon apprentissage d Paris. J'espère que vous trouverez dans cette ouvrage un peu de la dynamisme, que j'ai appris chez vous et que j'ai tant apprecié.

Zeergeleerde DAL, jou ben $1 \mathrm{k}$ veel dank verschuldigd voor de keramische kleimonsters waronder zeer bruikbare waren. Ook $U$, zeergeleerde HAMILTON, veel dank voor de kleimonsters uit de collectie van het Indisch Instituut, die $U$ me zo ruimschoots ter beschlkking stelde. Ook Prof. MOHR spreek ik daarvoor mijn erkentelijkheld uit.

A mis amigos, el professor HOYOS de CASTRO y doctor MATEU, muchas gracias por las muestrag de suelos de Espana y las de Marrueccos espanol.

Zeergeleerde DOEGLAS, zeergeleerde FAVEJEE, zeergeleerde de GRAAFF, ook aan $U$ veel dank voor de ondervonden medewerking. Zeergeleerde MIDDELBURG, ik hoop ook in de toekomst nog veel van $O w$ ervaring te mogen profiteren. 
Jou, zeergeleerde van SCHUYLENBORGH, ben ik ten zeerste dankbaar voor je vriendschap en je voortdurende belangstelling. Ik reken op een nauwe samenwerking in de tropen.

De Heren H.GOETSCH en J.J.REINDERS dank ik voor de uitvoering van enige experimenten en voor de betoonde vriendschap.

Een woord van hartelijke dank voor de prettige samenwerking aan mijn collega's Drs A.H.BLOKSMA, Ir G.E.van DIJK, Ir A.JANSE en J.H.van KAMPEN is niet misplaatst.

Met jullie, de Ingenieurs BOLT, BROESHART, ILAGERWERFF, SÄNGER en WALRAVE, hoop ik in de toekomst nog nauw samen te werken of contact te onderhouden. Veel dank voor je vriendschap en de destifds betoonde hulpvardigheid.

ANTOON HOEGEN en JOHAN van ECK, bekwame landbouwers, $U$ dank ik voor de wijze warop ge mij veel hebt geleerd van de practische landbouw. De tijd, in Uwe gezinnen doorgebracht, is voor $m i j$ van grote warde gèweest. Hetzelfde geldt HENK van BEEK.

Ook aan jullie, J.BAKKER, H. en J.BUDDING, J.G.J.KOK en A. MULLER, ben ik veel dank verschuldigd voor de betoonde hulp.

Een apart woord van dank komt toe an de Heer B.W.MATSER, die mij op snelle en accurate wijze heeft bijgestaan en aan de Heer G.BUURMAN, die het tekenwerk verzorgde.

Zonder jullie echter, E.J.JANSEN †, W.GEURTSEN, P.JANSEN, H.KNOOP, W.IOOYEN, C.A.KOK en M.POST zou dit werk niet geworden zijn wat het thans is. Ik dank jullie voor je steeds betoonde hulpvaardigheid. Ook de Heer FRIES veel dank.

Tenslotte, maar geenszins het minste, dank ik mijn VADER en MOEDER voor het ongeteld vele dat $z i j$ op onnavolgbare wijze voor de vorming van hun kinderen hebben gedaan. Aan jullie en aan DYMPHINE, die mij vol opoffering heeft bijgestaan bij mijn werk, is dit proefschrift in dankbare liefde opgedragen. 


\section{TABLE OF CONTENTS}

Voorwoord (Preface)

Chapter I : The development of differential thermal analysis as a method for clay mineral identification . . . . . . . . . . . 11

$\S 1$ Introduction . . . . . . . . . . 11

$\S 2$ Historical . . . . . . . . . . . 12

$\$ 3$ Qualitative interpretations . . . . . 13

$\$ 4$ Quantitative interpretations : . . . . 18

$\S 5$ The purpose of this study . . . . . 19

Chapter II : Description of the equipment and of the materials used for testing ........ 21

$\$ 1$ The equipment; the furnace and the equipment controlling the temperature rise.................. 21

$\S 2$ The sampleholders . . . . . . . . 25

$\$ 3$ Furnace temperature recording and difference temperature recording equipment . 27 Calibration of the thermocouples . . 28

$\S 4$ The usefulness of the equipment . . . 30

$\S 5$ The materials used for checking . . . 31

Chapter III : An account of the factors which determine the shape of DTA curves... . . . . . . 34

$\S 1$ Introduction . . . . . . . . . . 34

Part 1 Experimental factors . . . . 35

$\S 2$ The influence of rate of temperature rise 35

$\S 3$ The influence of the nature of the sample block .............. 38

$\S 4$ The effect of depth and radius of the sample holes... . . . . . . . 40

$\S 5$ The effect of the placement of the differential thermocouple junctions . . 42

$\S 6$ The influence of the nature and proportions of the thermocouples. . . . 42

$\S 7$ The effect of the inert substance . . . 43

$\S 8$. The effect of the tightness of packing in the sample holes . . . . . . . . 46

\$ 9 The effect of covering the sample holes 48

$\S 10$ The influence of the composition of the furnace atmosphere . . . . . . 50

Part 2. The clay bound foctors . . . . 52

$\$ 11$ The nature of the clay mineral(s) present 52

$\$ 12$ The effect of degree of crystallization 54

\$ 13 The effect of the adsorbed cations. . . 56 
$\$ 14$ The influence of admixtures in the clay. 61

$\$ 15$. Summary of the relative importance of the factors; final remarks :. . . . .

Chapter IV : Theoretical considerations of the differential thermal analygis............ 67

$\S 1$ The theory of heat transfer as applied to DTA .............. 67

$\$ 2$ The kinetics of some reactions recorded with DTA . . . . . . . . . . 72

$\$ 3$ Peak ohifting and the qualitative expression of DTA curves . . . . . . . 79

$\$ 4$ Quantitative analysis with DTA...... 82

Chapter $\nabla$ : The comparison of DTA records obtained with different equipments... . . . . . 84

Chapter VI : Some applications of differential thermal analysis to pedology . . . . . . . . 89

$\$ 1$ The application of DTA to the prospection of potassium fixation in clays... . 89

$\S 2$ DTA of mutabilites and metastabilites In so11 clays ........... 91

$\S 3$ Miscellaneous results; illites in troplcal solls; curves of Dutch soils . . 93

$\$ 4$ Reaction ranges and reaction intensities of various minerals, as recorded with DTA . . . . . . . . . . 95

Samenvatting

Appendix I : The solution of the differential equation

$$
\frac{d T}{d t}=a\left(\frac{d^{2} T}{d r^{2}}+\frac{1}{r} \frac{d T}{d r}\right) \text { as applied to DTA . . . } 100
$$

Appendix II: Some considerations about standardisation

of DTA equipment ............. 104

Ilterature clted . . . . . . . . . . . . . 107 


\title{
THE DEVELOPMENT OF DIFFERENTIAL THERMAL
}

\author{
ANALYSIS AS A METHOD FOR CLAY \\ MINERAL IDENTIFICATION
}

\$1. Introduct $10 \mathrm{n}$.

The heating of clay minerals causes more or less discontinuous changes in their composition and constitution. These changes are accompanfed by certain heat effects. Thus loss of water and loss of $\mathrm{CO}_{2}$ invariably are endothermic reactions. By means of the differential thermal analysis (DTA) these heat effects may be recorded in a convenient way as a function of temperature. Thereto a certain amount of clay, contained in a sample holder, is heated in a furnace from room temperature to about $1000^{\circ} \mathrm{C}$ or even higher. At the same time a thermally inert comparison substance is heated under the same conditions. The furnace temperature is measured by means of a thermocouple, usualIy mounted in the inert substance, while the reactions in the clay sample are measured by means of a differential thermocouple. One junction of the differential thermocouple is mounted in the clay sample and the other junction mounted in the inert substance. The differential thermocouple arrangement was first developed by WALIACH. (see 280) ${ }^{*}$ ). In temperature ranges where no reaction occurs in the clay, the temperature difference between the clay sample and the 1nert sample is zero, and the e.m.f. of the differential thermocouple is zero. An endothermic reaction in the clay causes a lag in temperature of the clay sample behind the temperature of the inert substance. The resulting temperature difference is recorded by the differential thermocouple. For exothermic reactions the e.m.f. of the differential thermocouple is in the opposite direction to that for endothermlc reactions. Thus reactions in the clay sample, accompanied by any heat effects, whatsoever, may be followed as a function of the temperature of the inert substance. In fig. 1 a schamatic representation is given of a DTA-curve of montmorilIonite, showing the reaction temperature range, the intensity of the reaction and the recorded algn of the leat of reaction.

*) The f1gures in parentheses refer to 11terature cited, p. 107 


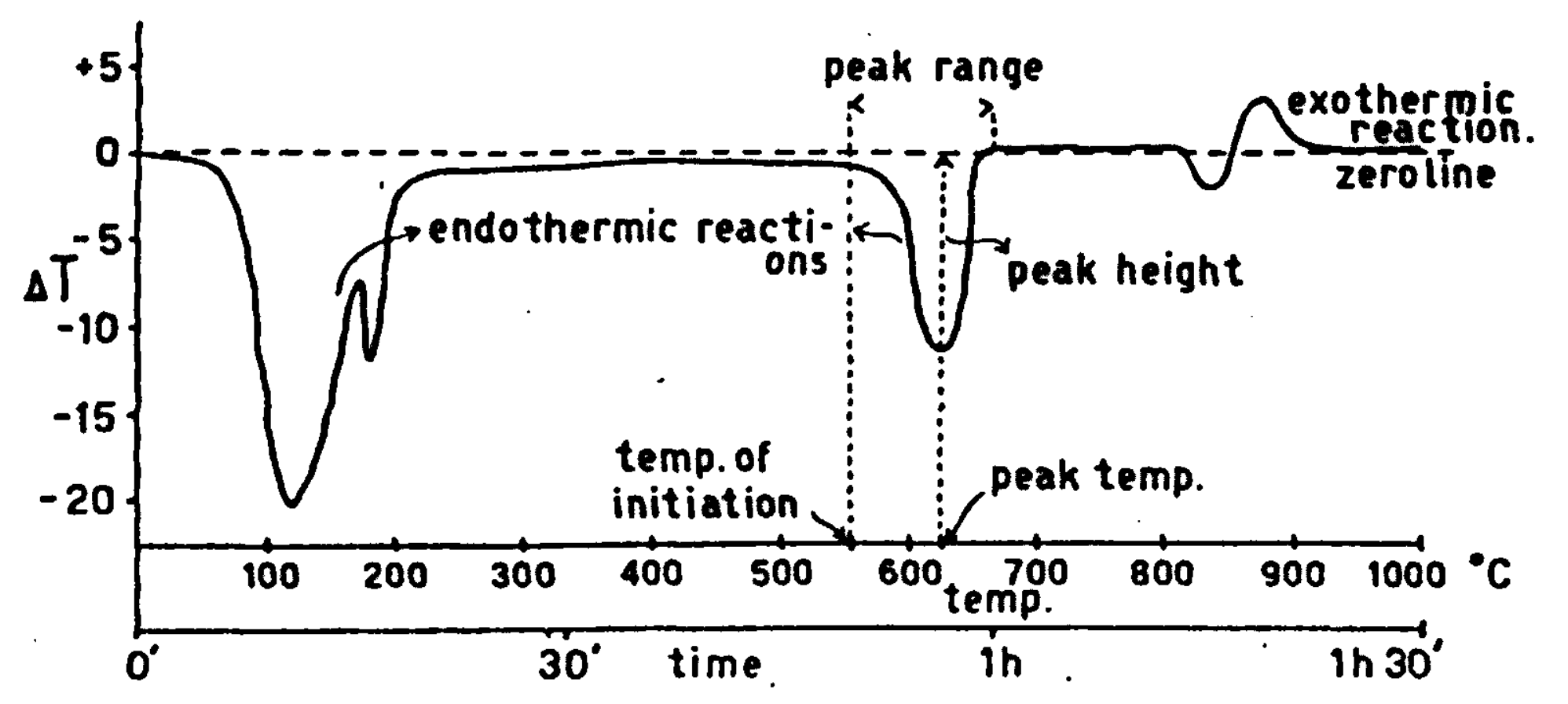

fig. 1. Schematic representation of a DTA curve of Ca-montmorillonite, showing endothermal and exothermal reactions, peak temperature, peak range and peak height.

The reaction rangea, the intensity of the reactions and the sign of the heat of reaction, are typical for the different clay minerals, thus enabling their distinction and identification.

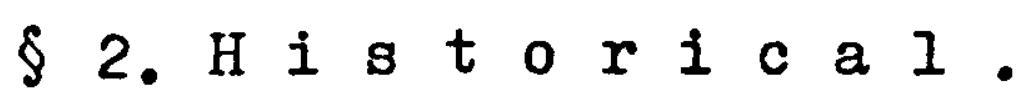

IE CHATELIER (54) was the first to apply thermal analysis to clays. As early as 1887 he distinguished five different clay species, with regard to their thermal behaviour, viz. halloysites, allophanes, kaolinites, pyrophillites and montmorillonites.

The method, later improved by WALIACH and then called the differential thermal analysis, remained unknown for a long time. The first workers, who used the DTA after IE CHATELIER were the ceramists $(86,147,273,284)$ and pure mineralogists (225-227, 179), while applications to pedology, to agricultural soils and clay separates, were first made in 1935 by AGAFONOFF and JOURAVSKY $(1,2)$. After 1935 the importance of clay mineral research became widely recognized and the method rapidly popularized all over the world. The main advantage of DTA over $X-r a y$ analysis, lay in the fact that the equipment used for DTA is relatively olmple, so that even the smallest laboratories could be equipped with it. For descriptions of the equipment see: $21,24,26,39$, $46,91,104,107,116,135,141,152,158,174,177,219,226$, $228,253,254,271,276$.

In the course of the years many improvements of the technique have been proposed. These improvements were mainly concerned with the recording and controlling equipment. IE CHATELIER 
and SALADIN (see 41) described the use of a prism of Iissajous to connect the lightbeams of the two recording galvanometers to one beam. The movement of the light beam from one mirror occurs in a horizontal plane, from the other, in a vertical plane. After passage through the Lissajous prism the horizontal movement of the light spot describes the temperature rise of the furnace and the vertical movement describes the temperature difference between cłay and inert substance. This prism device is still used in several French and Belgian laboratories (CAILLERE and HENIN, MUNIER, WAEGEMANS, etc.). The main improvement to the technique seems the use of electronic equipment, a.0. described bJ KERR and KULP (174), for controlling and recording purposes. As will appear from chapter 4 , the rate of temperature rise of the furnace is of outstanding importance for the result. So a constant heating rate, expressed as ${ }^{\circ} \mathrm{C}$ per unit of time, may considerably simplify the interpretation of the recordings. There are various other ways to obtain a constant heating rate (e.g. the use of variable resistances or of variable transformers) but electronic controlling equipment probably is the best. The use of an amplifier for an improved record of the differential temperature is described by BECK (21), HENDRICKS and coworkers (141) described a portable DTA equipment, for use in field stations.

Due to the fact that many factors, involved in determining the general shape of DTA curves, were underestimated or unknown, there appeared many controversial papers as to the applicability of the method. A number of investigators $(148,187,237)$ rejected the method, but most of the others persisted in the use of it. It is the objective of the present study to point out the factors, which are important in determining the shape of the curves.

\section{§3. Qua I I t a t 1 ve 1 nterpretations.}

For qualitative purposes (identification) the method has proved to be useful due to the work of CAIIIERE and HENIN (41), HENDRICKS and ALEXANDER (135), NORTON (219), GRIM and coworkers (104, 105), KELTEY (166), SPEII and coworkers (271), GORBUNOV (94.) and others.

The following measurable items are of interest in the qua litative interpretation of recordings (for explanation see flg. 1):

a. the general shape of the curve, determined by the nature 
of the clay under consideration;

b. the temperature range of the reactions, as measured from the initiation (departure from the zero-line) to the end (return to the zero-line);

c. . the temperature at the maximum rate of reaction (peak temperature);

d. the intensity of the reactions, measured, for the time being, as the peak-height.

These quantities differ for the different clays, even within the same clay-mineral group.

The best described thermal reactions are those accompanied by $10 s 8$ of material, as for instance dehydration reactions. These reactions were already known from early thermal analysis records, where the losis-in-weight upon heating was plotted against temperature. Especially the dehydration reaction of kaolinite, which is known to occur from about $430^{\circ} \mathrm{C}$ to $650^{\circ} \mathrm{C}$ has received considerable attention ( 237 ), because of its industrial Importance.

The kaolinite minerals, the halloysites and the hydrous oxydes of $A I$ and Fe give the most easily distinguishable results with DTA. The reactions exhibited by these minerals upon heating are of fairly strong intensity, and limited to a well defined temperature range. The minerals of the montmorilionite group and, still more, the illite minerals usually yield curves with reactions of relative low intensity, the reactions being variable over a wide temperature range. This behaviour probably is caused by the variable chemical composition of the latter minerals. The first fairly good DTA curves of illites were given by GRIM and his coworkers (100, 105). The vermiculites are also rather variable with regard to thermal decomposition. The carbonates on the other hand yield pronounced curves, exhibiting reactions of strong intensity. In chapter 6 , table the reaction ranges and the reaction intensities for the different minerals occuring in the clay fraction of soils are summarized.

A comparison of DTA curves with dehydration curves, obtained by plotting weight-loss upon heating against temperature reveals that the results may diverge considerably. The DTA curves show the reaction 'ranges and the maxima' of the reactiong. at higher temperature, than do dehydration curves. The difference is probably one which may be expected upón comparing a dynamic (continues) process (DTA) with a static (discontinues) process (stepwise dehydration). In chapter 4 the implications of this statement will be developed further. 
Comparison of curves of one and the same sample of clay, submitted to DTA in different equipments, as has been carried out by DE LEENHEER (187) and MACKENZIE (191), indicated that DTA curves may have no general validity. The differences of reaction temperatures from the same sample of clay amounted to $150^{\circ} \mathrm{C}$ or more, when curves resulting from different equipments were compared. The present author has indicated (12) that the cause of the discrepancies is to be sought, for primarily in the nature of the furnace and the temperature recording and controling equipment. It is to be expected that the difficulties in the interpretation of curves $\mathbf{w 1}$ increase as do the number of different kinds of equipment.

Some of the interpretative difficulties have already been clarifled by HOULDSWORTH and COBB (147), PIETERS (237) and JEFFRIES (158). The former authors emphasized the importance of the rate of temperature rise of the furnace upon the thermal curves of kaolinites. The steeper were the heating rates, the more did the measured reaction temperatures diverge from the true reaction temperatures known from static measurements. The phenomenon of displacement of reaction temperatures is called peakshifting. PIETERS has pointed out that there is an influence of the partial vapour pressure of water in the reaction medium upon the temperature of dehydration of kaolinite. High partial vapour pressures of water maj cause a delay of this reaction amounting to $170^{\circ} \mathrm{C}$. From JEFFRIES work it follows that the heat capacities of the clay sample and the inert sample should be equal, if one is to obtain straight zcro-lines for the temperature ranges where no reaction occurs.

For reactions not accompanied by any $108 \mathrm{~s}$ of material the comparability of DTA curves is much better. Examples of such reactions are the conversion of $\alpha$-quartz into $\beta$-quartz at $573^{\circ} \mathrm{C}$, the exothermic reaction of kaolinite at about $950^{\circ} \mathrm{O}$ and the conversion $\mathrm{Y}-\mathrm{Fe}_{2} \mathrm{O}_{3}-\alpha-\mathrm{Fe}_{2} \mathrm{C}_{3}$ at about $510^{\circ} \mathrm{C}$. The reaction temperatures in these cases are fairly well defined; the intensity of the reactions, however, may be modified considerably, as will be shown in chapter 3 .

In table 1 a number of references is given referring to the literature on qualitative interpretation of DTA curves from the various clay minerals indicated. 
Reference table to the literature on qualitative interpretation of DrLcurves from various minerals present in soils and clays.

The numbers refer to. I1t. cit., pag. 107:

Group

- Oxides and hydrous oxides

Kaolinitegroup

Montmorillonite Broup
Kinerals

Al-hydroxides

Fo-hydroxides

Quart:

In-oxides

Kaolinite

Firo-clay-min.

Dickite

Anauxite

Nacrite

Halloysite

Kontmorillonite

Beidellite

Nontronite

Hectorite.

Saponite
Reforences

$3,8,21,24,26,46,54,94,105$ $123,166,174,179,218,219,220$ $226,270,271$.

$3,21,24,26,52,105,166,174$, 259,270 .

$21,24,25,26,78,86,105,109$, $123,166,174,177,270$.

232.

$1,3,4,7,8,21,24,26,41,46$, $54,60,64,91,94,99,101,104$, $105,107,116,117,123,135,147$, $152,158,166,174,177,179,187$, $219,220,226,227,251,254,270$, $271,275,284$.

$60,91,104,105,107,174,220$, $270,271$.

$21,94,152,174,270,271$.

$21,152,174$.

174 .

$21,24,26,41,45,46,54,64$, $91,94,105,123,158,166,174$, $179,219,270,271$.

$1,3,4,7,21,24,26,39,41$, $43,46,54,60,91,94,99, .100$, $101,104,105,116,123,135,139$, $158,166,174,177,179,219,226$, $227,228,236,251,254,262,270$, 271.

$3,24,46,166,174,219,228$, 251,271 .

$9,45,46,90,174,177,185,226$.

$5,45,166,174,177,228$.

$21,94,174,228$ : 
I A B I E 1. (continued)

aroup

Koa group

Carbonates

Phosphates

Clay-organic matter complexes

Calcito

Various
References

$44,45,46,158,174,270$.

$3,7,9,15,21,24,-26,39,41$, $46,59,60,91,94,99,100,101$, $104,105,135,158,166,174$, $179,219,251,254,270,271$.

Vermiculite $15,16,57,146^{8}, 278$.

Chlorites

$3,5,46,50,225$.

Intigorite

Pyrophilite

Magnesite.

Dolomite

Aragonito

Siderite

Other carbonates

$47,48,225$.

$45,54,123,179$.

$22,24,26,46,61,77,79,80$, 105,174 .

$22,24,26,46,61,77,105,174$. $22,24,26,46,61,77,105,174$. 79,80 .

$21,22,61,89,173,249$.

$22,61,174,178$.

197:

$2,9,31$. 
But is must, however, be emphasized that correct qualitative interpretation of thermal curves is impossible without knowledge of the factors underlying the lags in reactions. The way in which these factors may be evaluated will be considered in chapter 4 .

Finally it may be stated that nowadays the opinion prevails (191) that DTA curves obtained with one and the same equipment, operating under strictly reproducable conditions, are comparable among themselves, so long as operating conditions are kept constant. The generalization of results among different equipments which do not operate under identical conditions, is still a matter of considerable difficulties. In other words: the method is strictly conventional (12).

Nevertheless it will be shown in chapter $V$ how the generalization of results may be approximated.

§4. Quantitative interpretation.

The first quantitative interpretations of DTA curves were made by AGAFONOFF (1). Visual comparison of curves, drawn from artificially prepared mixtures of clay minerals, with curves from N.-African clays, gave an impression of the relative quantities present in the latter. NORTON (219) suggested, that the magnitude of the galvanometer deflection accompanying a thermal reaction (measured as the height of the peak), would be proportional to the quantity of the mineral present. This same view is held by GRIMSHAW and coworkers (108). Several other investigators, as ALEXANDER, HENDRICKS and NELSON (7), SCHAFER and RUSSELI (254), SPEII and coworkers (271), KERR and KULP (174) have considered the area under the reaction peaks to be proportional to the concentration of the mineral under consideration. The former authors (7) derived the relation empirically, the latter (174) both empirically and theoretically. The observations made by DEAN (64) however are in disagreement with the supposition that the area under the peak is proportional to the concentration of reacting material. DEAN considers the cosecant of the peak angle as a quantitative measure, though his material is restricted to the clay minerals showing pronounced endothermic reactions.

JEFFRIES (158) attacked the problem from a totally different view point, putting the heat capacity of the clay sample before and after a reaction as a measure of the relatire quantities present. 
From the avallable data, it is possible to derive certain empirice? relations, with the restriction that these relations only hold for the operating conditions of the equipment under consideration.

It seems however doubtful, whether a correct understanding of quantitative DTA 18 possible without complete knowledge of the kinetics of the reactions. The derivation of a general relation between reaction-curve and the concentration of the reacting claymineral involves an understanding of

a. the kinetics of the reaction;

b. the heat-balance of the furnace, including the sample holder the clay and inert material and the heat supply to the reactant.

The kinetics of reactions of the type

$$
\mathrm{AB}_{\text {solid }} \rightarrow A_{\text {solid }}+\mathrm{B}_{\text {gás }}
$$

are rather obscure. The best known reactions of this type are the decomposition reactions of the carbonates $(150,286)$. Of the silicate minerals the kinetics of the dehydration of kaolinite has been the subject of a number of investigations. The early work is summarized by PIETERS (237). Of the later work that of MURRAY and WHITE (214) is of outstanding importance.'Its bearing upon quantitative DTA w1ll be discussed later.

About the role played by the movement of heat in the clay sample during a reaction, little is known until now, though its influence may be assumed substantial in view of quantitative thermal analysis (chapter 4).

\section{$\S 5 . T h$ e purpos e of $t$ h $i s$ s $t u d y$.}

From the foregoing discussion of the literature it appears that several basic quastions related to the (qualitative and quantitative) explanation of DTA curves are still unsolved, though the method is the eldest applied to clay research.

It is apparent that a number of factors, residing in the DTA apparatus, are to a great extent rate determining for the observed reactions. The first question is: what are these apparatus-bound factors and what is the relative importance of each of these upon the recorded result. In order to solve this question various furnaces, sample holders, thermocouples and sensitivity scales have been used in this study, while from a number of foreign laboratories analyses from the same sample of clay were obtained, with knowledge of their operating conditions. It 
will be shown in chapter IV and $V$ how these apparatus-bound factors may be adjusted, in order to generalize the results, and how these factors may be used to modify the recorded curves.

Besides the influences, resident in the equipment, there are properties, of the clay alone, which determine the course of DTA curves. The second problem is to reveal these latter factors, (particle size, cations adsorbed, degree of crystallization, etc.) and their relative influence on the recorded results.

If an answer is found to these two questions, the qualitative interpretation of DTA curves is considerably simplified, and the phenomenon of peak shifting, which is the crux of thermal analysis, might also be understood. There remains however the question whether there is any observable difference between the reactions, which are accompanied by loss of material, and the reactions, which are not accompanied by any loss of material. The answer to this question would enable one to correlate the logsin-weight upon heating data and dilatometer data with DTA.

Finally the question of quantitative DTA rises, but this question may not be solved without knowledge of the first three. Here the problem is to find a relation between the quantity of a clay component and the rate of reaction in a non-static reaction process, the rate determining factors and the time of reaction being known. This is a matter of considerable difficulty and will be the subject of part of chapter 4 .

With the answers to the foregoing question known, one can write down the items involved in an eventual standardisation - if wanted - of the DTA equipment. DTA standardisation will be the subjeat of appendix 2 . 


\section{DESCRIPTION OF THE EQUIPMENT AND OF THE MATERIALS USED FOR TESTING}

The equipment, needed for DTA consists of:

1. a furnace, ranging from room temperature to about $1000^{\circ} \mathrm{C}$;

2. equipment controling the temperature rise of the furnace;

3. a sample holder with room for clay sample and inert sample mounted in the furnace;

4. equipment for recording. the temperature of the furnace and for recording the difference in temperature between the clay and the inert sample.

The whole is arranged as is shown schematically in fig. 2. Many modifications of this arrangement are in use (BECK, BERKELHAMER, BERKELHAMER and SPEII, CAILIERE and HENIN, GRIM and ROWLAND, GRIMSHAW, HEATON and ROBERTS, GRUVER, HENDRICKS and ALEXANDER, HENDRICKS, GOLDRICH and NELSON, JEFFRIES, KERR and KULP, KULP and KERR, MUNIER, NORTON, SCHAPER and RUSSELI, SPEII BERKELHAMER, PASK and DAVIES, and others).

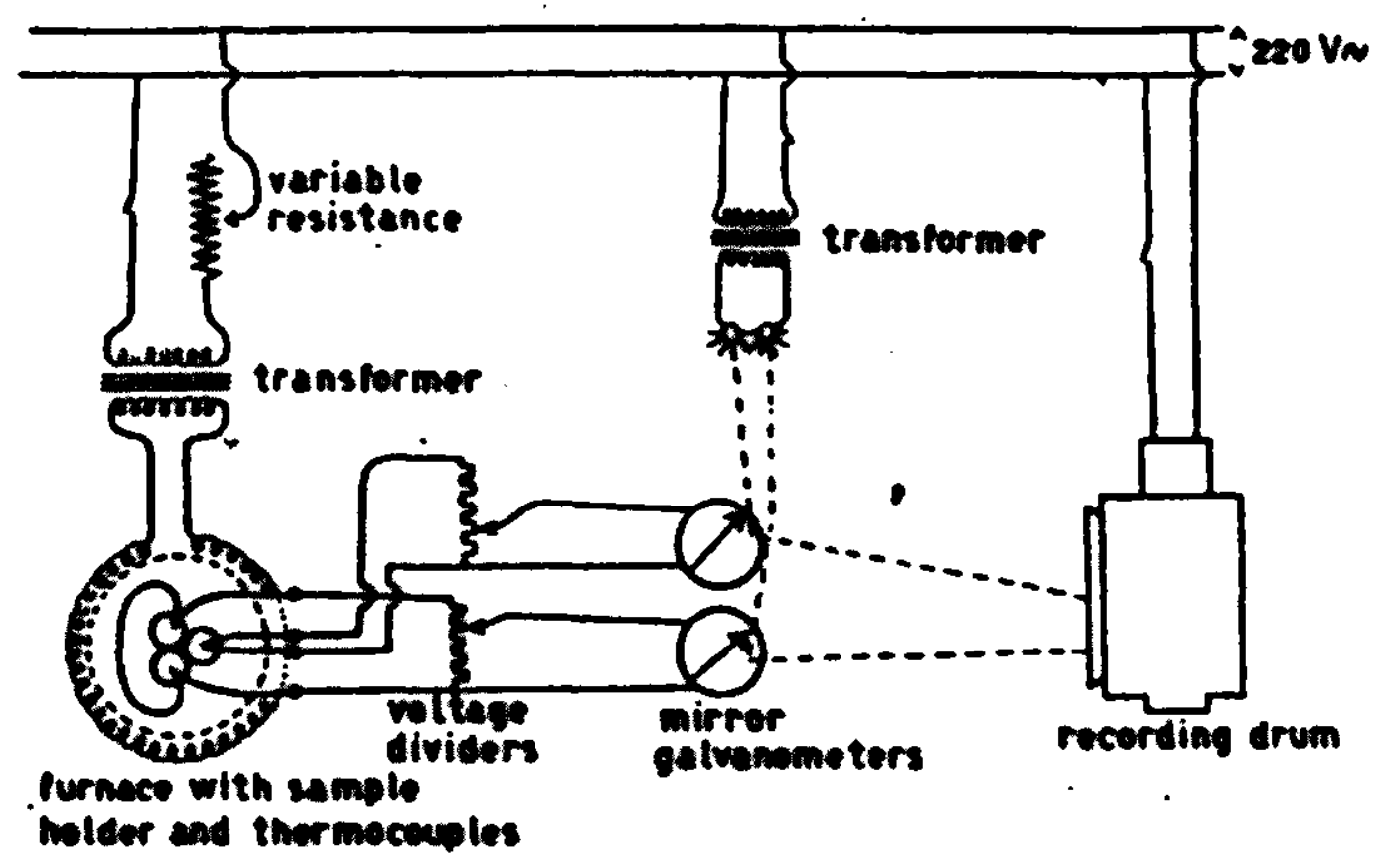

$118 \cdot 2$

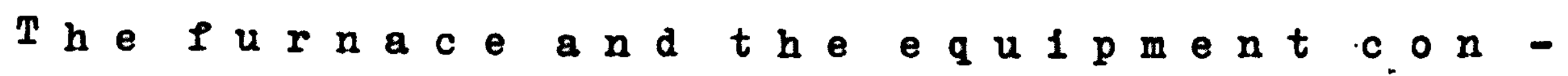
trol $r$ ing the $t$ e m perature rioe.

In this study three types of furnaces have been used, designated as No. I, II and III. This was done in order to reveal any influence of the nature of the furnace.

Furnace No. I is a commercial Gallenkamp furnace, opera- 
ting on 220 volts a.c., with internal resistance of 21 ohms at room temperature and 26 ohms at 1000 degreeg $C$. The door of this furnace was removed and replaced by a slide constructed of high duty silica brick and mounted with a horizontal alundur platform in the middle, upon which the sample holler could be placed. The sample holder was filled outside the furnace, and afterwards placed on the platform: After the placement of the thermosouples in the clay sample and in the inert substance, the slide was introduced in the furnace. The arrangement of furnace, slide, sample holder and thermocouples is shown in $11 \mathrm{~g} .3$.

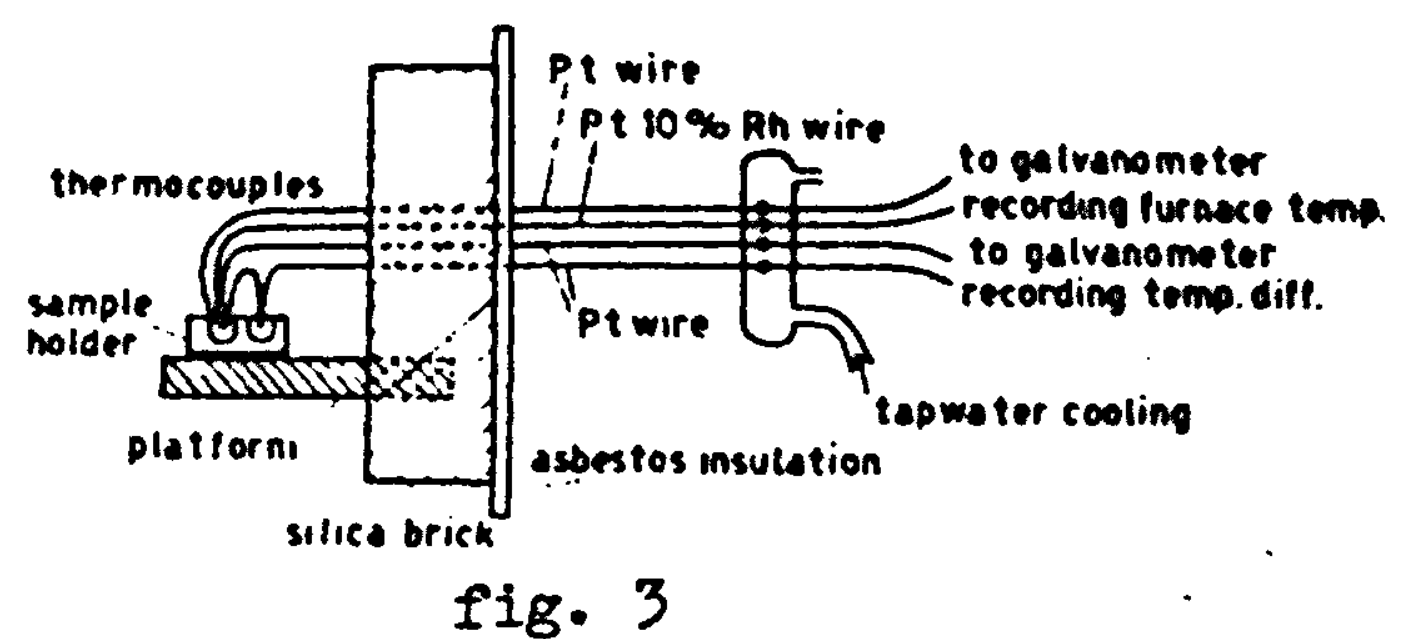

The rate of heating of this furnace was manually controlled $t y$ a variable resistance ranging from 40 to 0 ohme, thus enarling a temperature rise of about 8 degrees $C$ per minute (see fig. 6).

Furnace No. II is a home-designed DTA-furnace, the diameters of whish are given in $\mathrm{Pig} .4^{*}$ ). This furmace had the main advantage that the active space was small, and that heating took place from all sides, enabling a very regular temperature rise. The total internal resistance was 2.2 ohms at room temperature and 2.4 ohms at $1000^{\circ} \mathrm{C}$, the heating element being Kanthal-A wire, diameter $1.8 \mathrm{~mm}$. This furnace operated maximally under 40 volts a.c., delivered via a transformer $380 \mathrm{~V} / 40 \mathrm{~V}$. In the primary current of the transformer a variable resistance (60 - 0 ohms) was placed, enabling a temperature rise of about 13.5 degrees per minute (aee $11 \mathrm{~g}$. 6).

*) The refractory bricks were produced by N.V.Chamotte Unie, Geldermalsen. We are Indebted to Ir G. van GIfn and $H$. van Dijk for their assistance in the design of the furnace. 


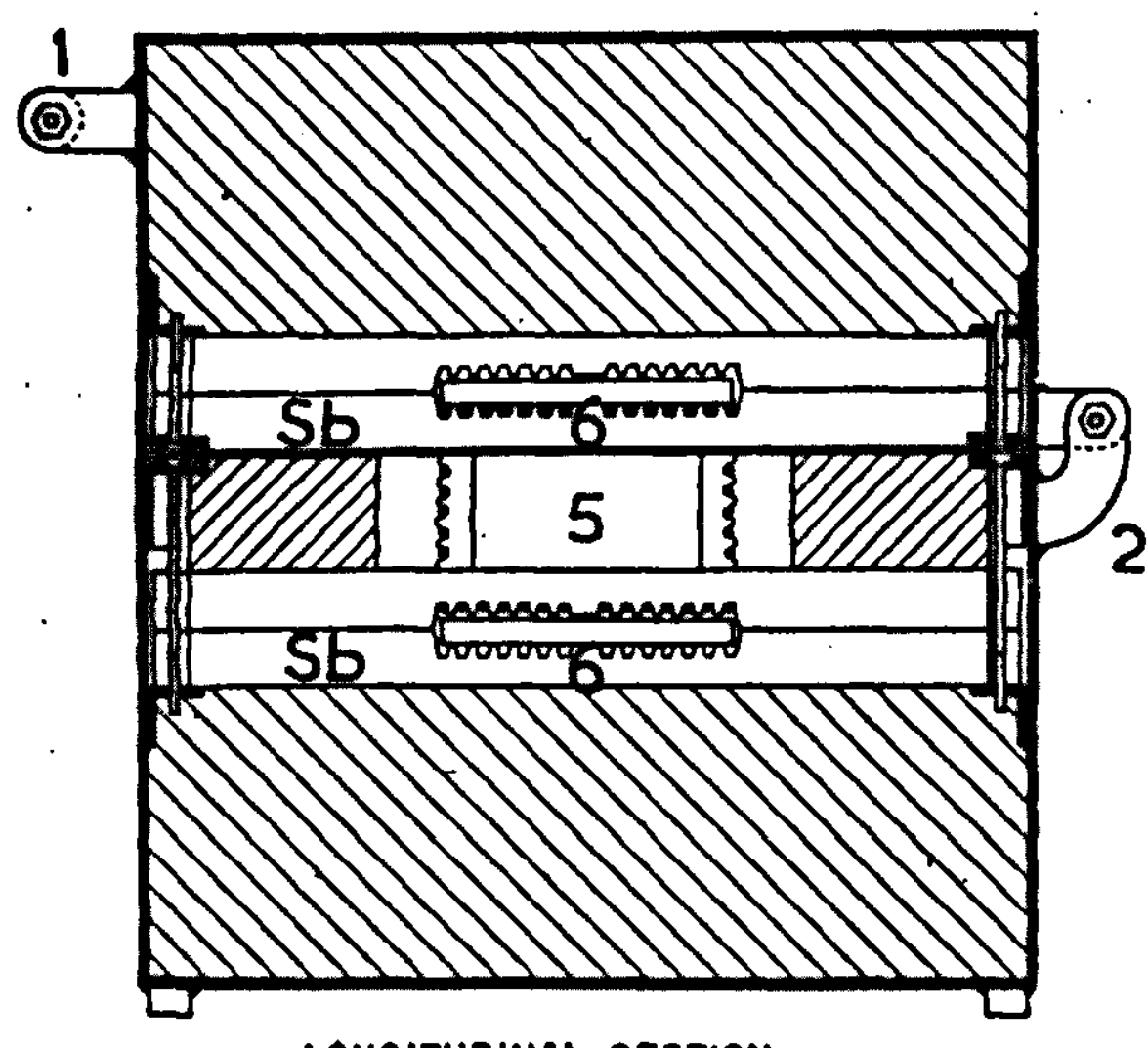

LONGITUDINAL SECTION

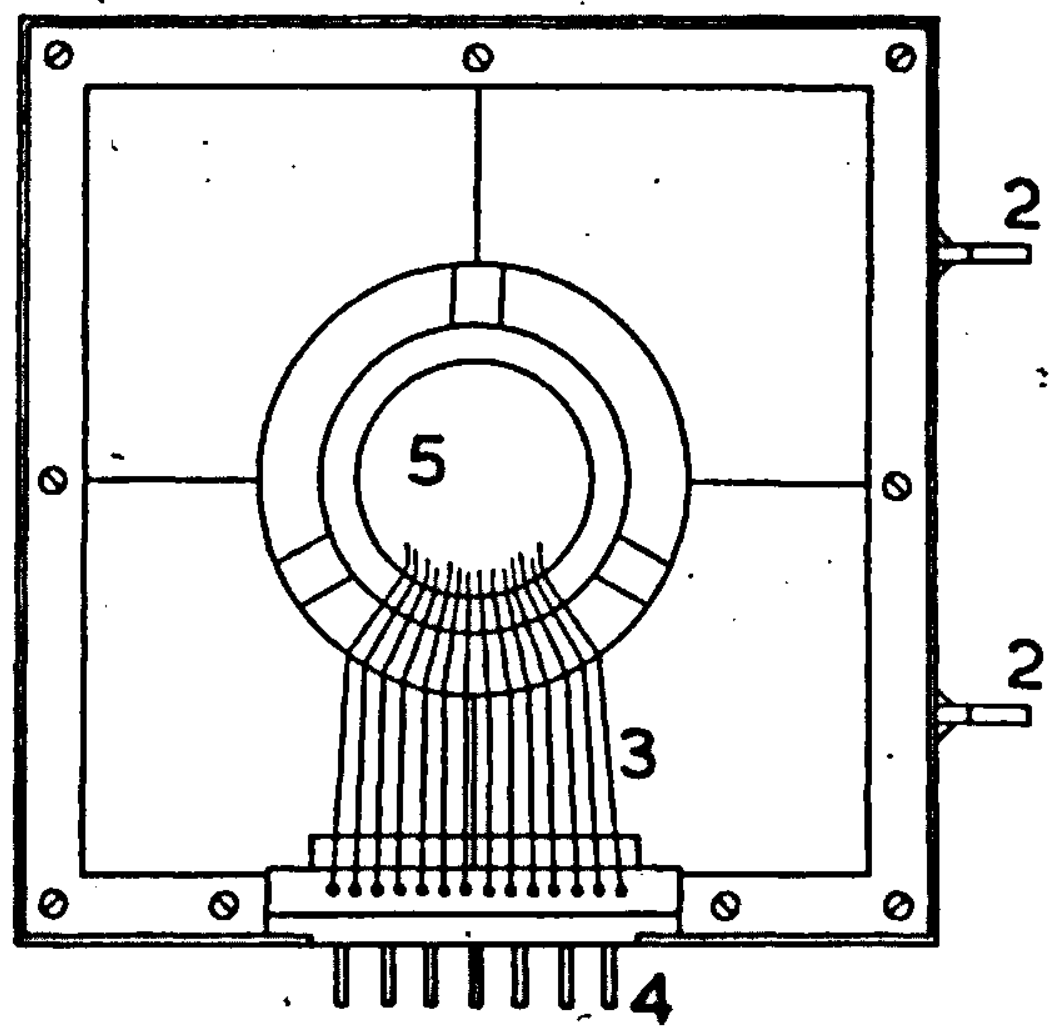

UPPERSIOE OF FURNACE SPACE (cover removed)

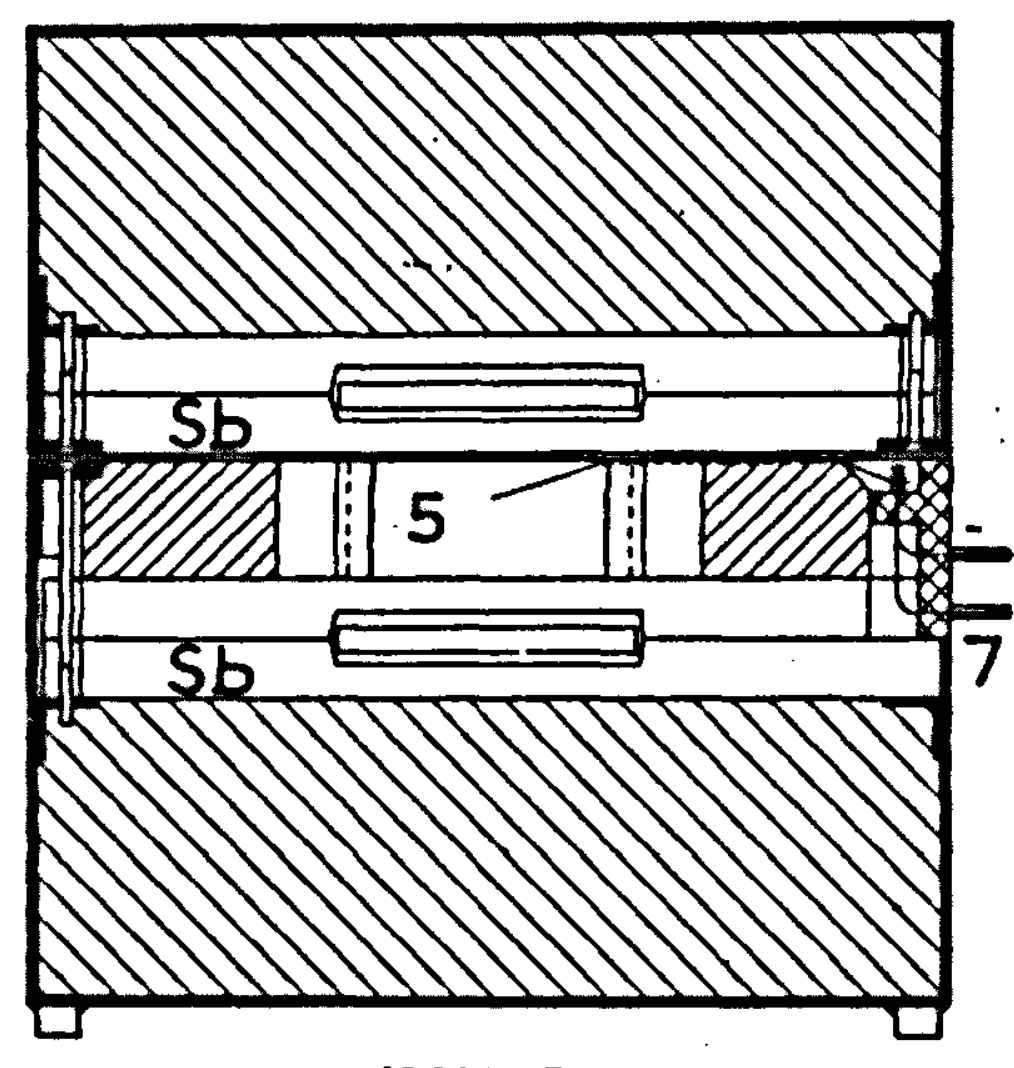

CROSS-SECTION

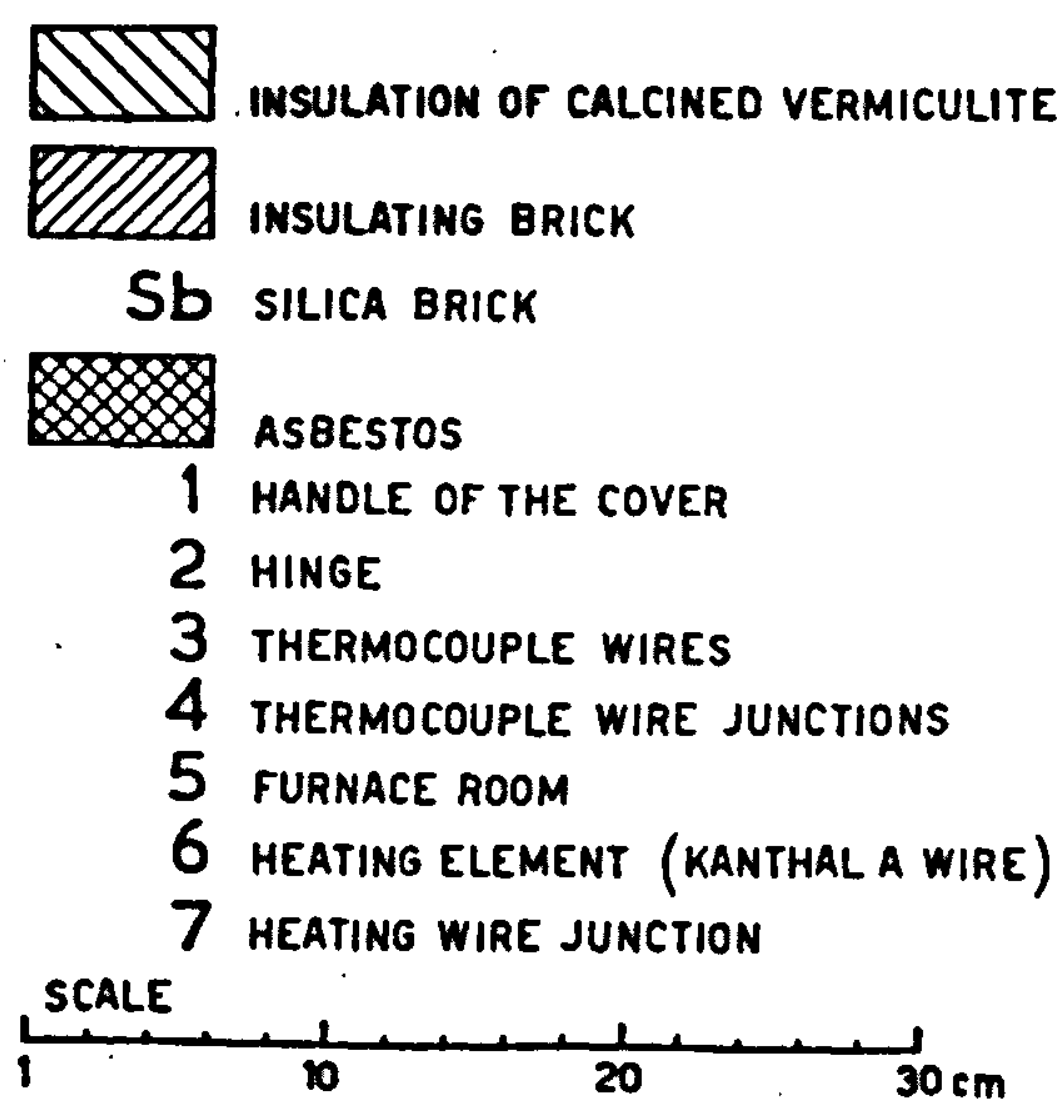

FIG. 4

Furnace no.II, designed by

N.V. Chamotte Unie Geldermalsen.

Most of the experiments, mentioned below, were carried out with this furnace.

Furnace No. III is a commercial Heraeus tube furnace operating on 127 volts a.c. with internal resistance of 35 ohms. The internal diameter of the tube was $3 \mathrm{~cm}$, the length of the tube $18 \mathrm{~cm}$. This furnace was hung, with vertical tube, between two pulleys and could be removed by means of two contra-weights to which it was attached with steel wire. In experiments with this furnace, the sample holder was fixed on a vertical alundum tube which just fitted into the lower end of the furnace tube. The arrangement of furnace, sample holder and thermocouples is 
shown in fig. 5 .

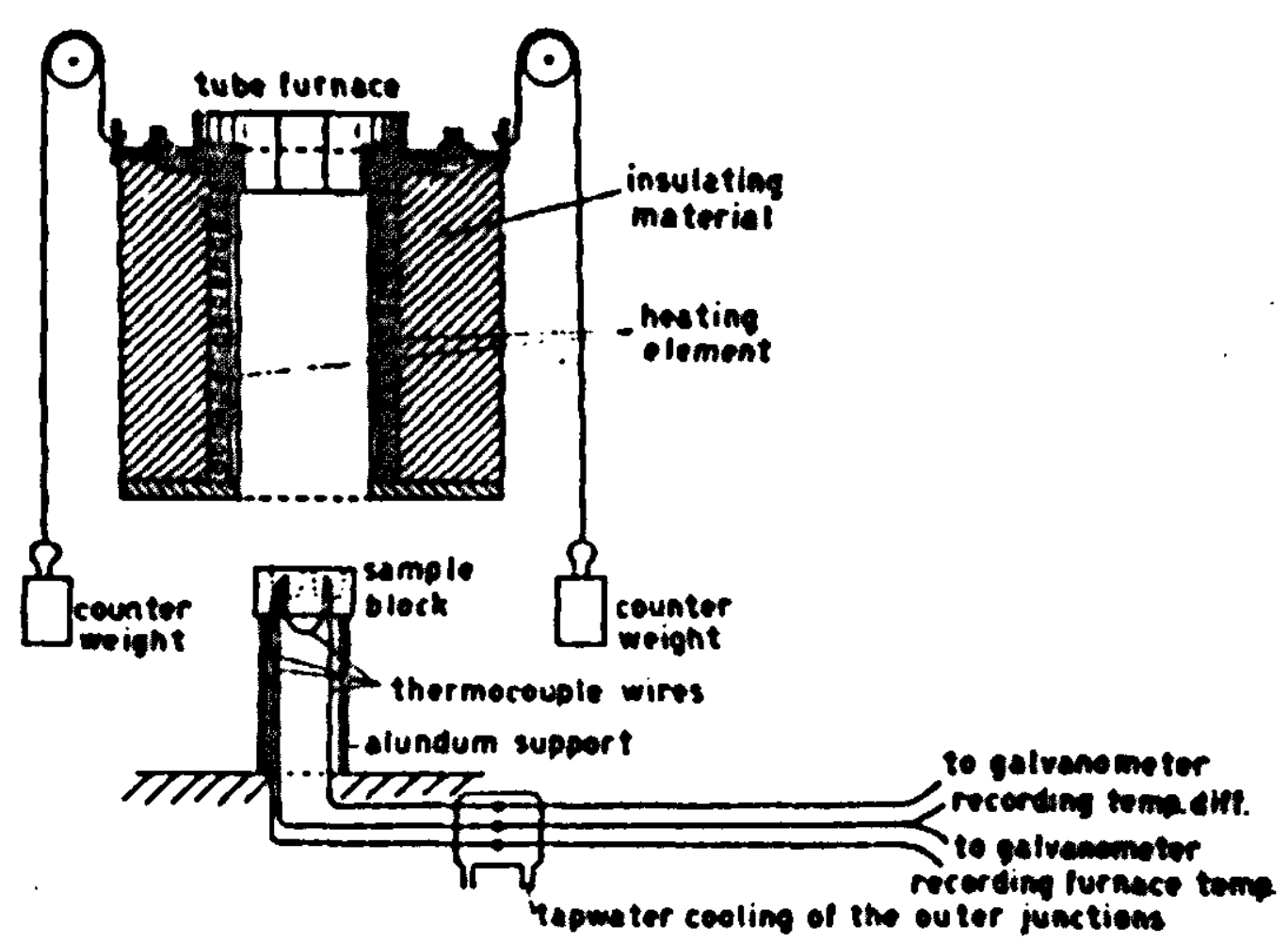

fig. 5

The heating rate of this furnace was accurately inear from 80 to $700^{\circ} \mathrm{C}$. By means of a variable resistance ranging from 44 to 0 ohms in the furnace current cfrcult the heating rate could be regulated and amounted to approximately 28 degrees $C$ per minute (see fig. 6).

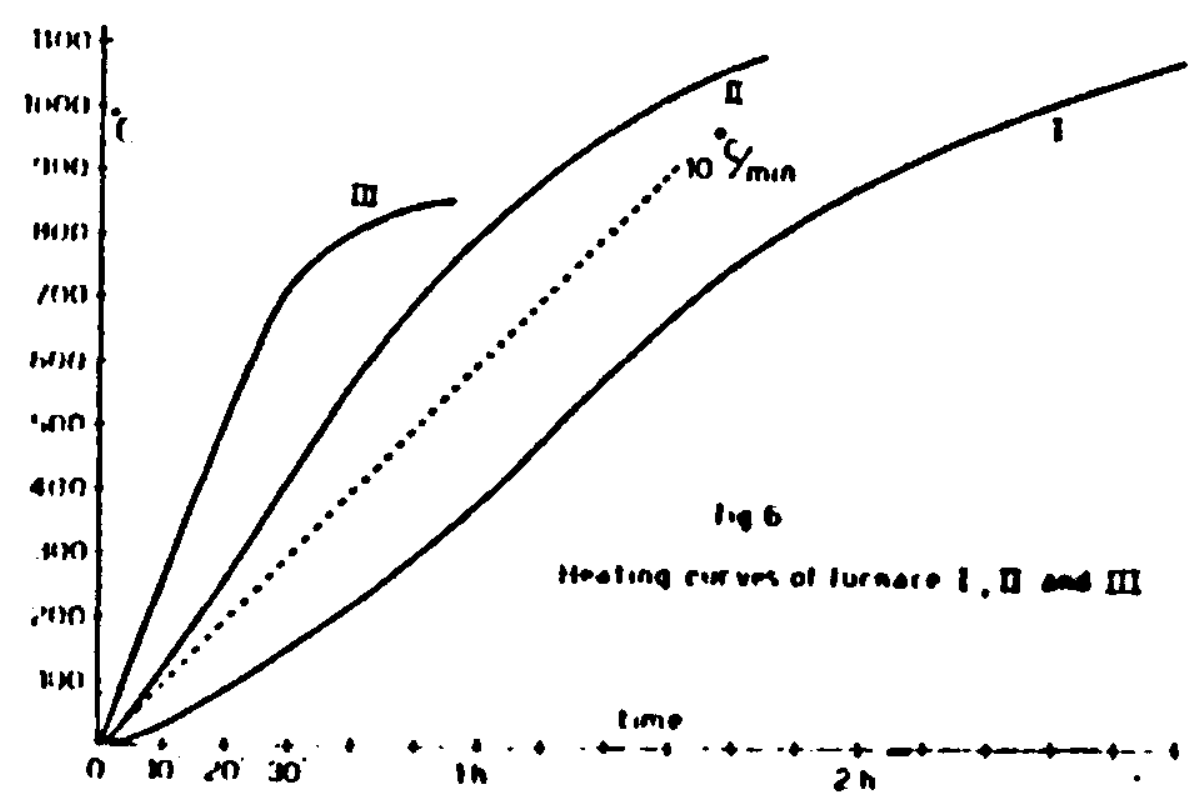

P1g. 6

In general it may be stated, that a great variety of furnaces is adaptable to DTA, but those having an approximate 11near temperature rise over the whole temperature range should be preferred. Adequate insulation is very important; the better the insulation is, the less it appears to be necessary to watoh over the regulation of temperature rise.

Further the furnace should answer the following conditions: low heat capacity of the active furnace space, for rapid response of furnace temperature to variations in heat input; high 
coefficient of heat transfer to the sample holder; good sized heating elements arranged in such a way that heat gradients in the furnace-room are minimized; and adequate closing to prevent air currents from disturbing the heating process.

In this studj no uge has been made of electronic controlling equipment for accurately. Iinear furnace temperature rise. It has been the primary objective to survey the suitability of DTA as a method of identification for clay minerals under divergent experimental conditions.

T he s a m p l e $-\mathrm{h}$ o 1 d e r s.

In the literature various types of sampleholders have been described. CAIILERE and HENIN work with quartz-glass tubes. Most Brittioh workers prefer ceramic sample-holders: MACKENZIE, ROBERTS and GRIMSHAW; MUNIER in Sevres; LEPINGLE in Brussels; and TAEGEMANS in Tervueren. In the U.S.A., however, sampleholders with high heat-conductivity coefficients are preferred (nlckel, inconel, platinum etc.). See the work of NORTON, HENDRICKS and ALEXANDER, GRIM and coworkers; SPEIL and coworkers; KULP and KERR, GRUVER, etc.

To cover the influence of the sample holder on the initiation and the course of the reaction, various types of containera have been compared. The following were used (see fig. 7):

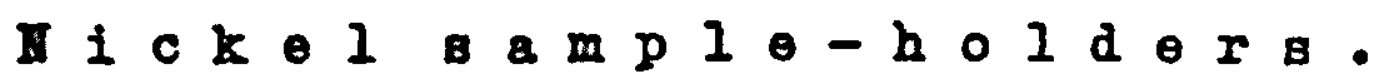

a. cylindrical block, diameter $45 \mathrm{~mm}$, height $18 \mathrm{~mm}$, with two holes, dianeter $10 \mathrm{~mm}$, depth $15 \mathrm{~mm}$;

b. rectangular block, $40 \times 40 \times 15 \mathrm{~mm}$, with two holes, diamoter $5 \mathrm{~mm}$, depth $9 \mathrm{~mm}$

c. rectangular block, $36 \times 36 \times 8 \mathrm{mr}$, with two holes, diamoter $6 \mathrm{man}$, depth 6 ings;

d. rectangular block, $48 \times 48 \times 16 \mathrm{~mm}$, with two holes, diameter $8 \mathrm{~mm}$, depth 12 and two holes oppositely located, diamoter 4 , depth 8 m

- rectangular block, $22 \times 8 \times 15 \mathrm{~mm}$, with three holes, diameter $6 \mathrm{~m}$, depth $12 \mathrm{~mm}$.

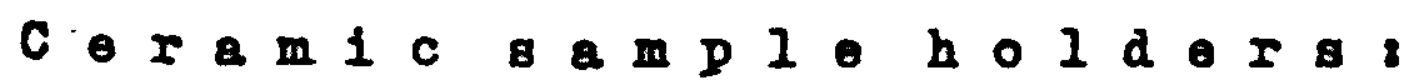

f. alundum tubes, external diameter $10 \mathrm{~mm}$, intermal diameter $7 \mathrm{~mm}$, depth $15 \mathrm{~min}$

8. alundum tubes, external diameter $5 \mathrm{~mm}$, internal diameter $3 \mathrm{~mm}$, depth $12 \mathrm{~mm}$

h. cylindrical block, dianeter $48 \mathrm{~mm}$, height $16 \mathrm{~mm}$, with two holes, diameter $11 \mathrm{~mm}$, depth $12 \mathrm{~mm}$

j. cylindrical block, with dianeter as h, but with two holes, dianeter $8 \mathrm{man}$, depth $12 \mathrm{~mm}$. 



i.
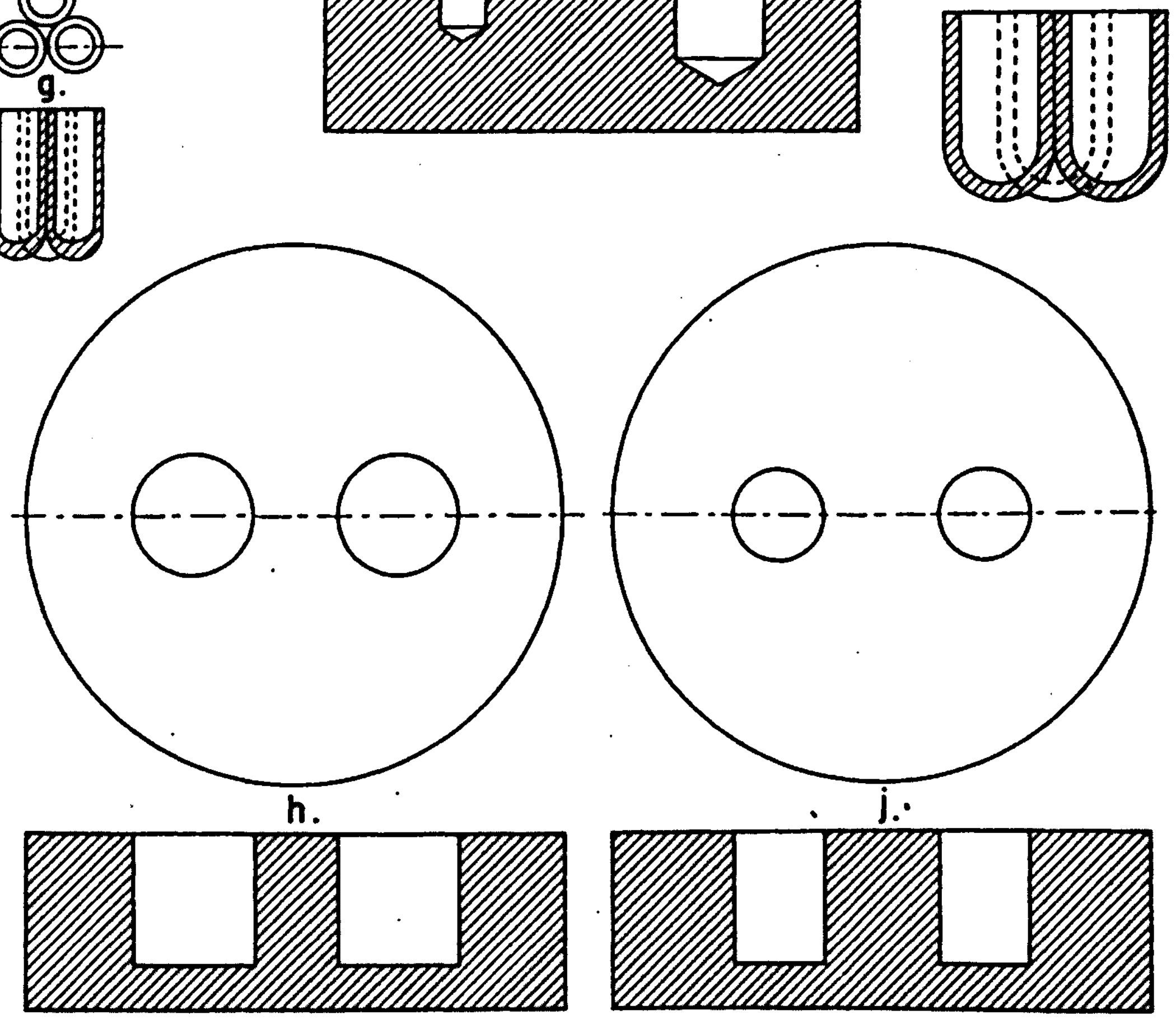

FIG. 7

Cross sections and longitudinal sections of the sample blocks $c, d, e, f, g, h$ and $j$, used in this study. 
Furnace $t$ emperature and d 1 e 1 e rence temperature recording equipment.

AII temperatureg were measured ky means of Pt - Pt $10 \% \mathrm{Rh}$ thermocouples. To atudy the influence of wire diameter two different sets of thermocouples were used, respectively with wire diameter $0.2 \mathrm{~mm}$ and $0.5 \mathrm{~mm}$.

In most experiments the furnace temperature junction was placed in the clay sample, though a number of experiments were made with the hot junction placed in the inert substance. The corresponding cold junction of this couple pas maintained at constent temperature, for which streaming tap water was used. The tapwater temperature differed from 12 degrees $C$ in early autum (maximum) to 8 degrees $C$ in early spring (minimum) and wes moasured at regular intervals. The difference of 4 degrees between spring and autum temperature of the cold junction was left out of consideration in the measurement of the furnace temperature. In most measurements 10 degrees $C$ was maintained as cold junction temperature and consequently the error is $\pm 2^{0}$ $C$, Ijing within the error of the observation.

The differential thermocouples had both junctions in the furnace, one in the inert substance, the other in the clay. Outalde the furnace the Pt wire-ends were attached to copper wires, both junctions with copper being maintained at the same constant temperature in a tapwater cooling device.

The recording equipment consisted of two Moll-original mirror galvanometers of high sensitivity ${ }^{*}$ ). One measured furnaoe temperature, the other differential temperature, the reflected lightbeams being recorded continually on photographic paper, mounted on a recording drum driven by a synchronous motor.

In both thermocouple circuits voltage dividers were placed to adjust the galvanometer deflections to the given width of the recording paper. The resistance of the galvanometer shunt had a constant value of 675 ohms for aperlodic damping. The e.m.f. of the furnace temperature thermocouple was divided $1: 100$, the result being that one centimeter recorded galvanometer deflection corresponded to 95 degrees $C$. The e.m.f. from the difference temperature thermocouple was much less divided; various sensitivity scales have been used, depending on the experimental conditions (sample weight, sample holder, velocity of temperature rise, etc.) and on the nature of the clay.

The sensitivity scales raried from $1 \mathrm{~cm}$ recorded deflecti-

*) Kipp en Znn., Delft, Moll-Original galvanometer. 
on for 22 degrees $\mathrm{C}$ to $1 \mathrm{~cm}$ deflection for 0.4 degrees $\mathrm{C}$ difference temperature. The time to reach equillibrium-deflection upon a sudden e.m.f. exposure was 1.2 sec. for both galvanometers, see fig. 9.

The recording drum had a circumference of $42 \mathrm{~cm}$ and an effective width of $12 \mathrm{~cm}$. Time of rotation was 160 minutes, 80 that for normal work with furnace No. II two subsequent recordings could be made on one film. The photographic paper used was Gevaert bromide paper of medium sensitivity, supplied with parrallel lines on $5 \mathrm{~mm}$ distance to facilitate reading of the curves (see fig. 8). After every two runs the paper was removed from the drum, developped in metholhydrochinon $1: 6$, fixed in acid fixative, washed and dried.

C a I I b r a t 1 o $\dot{n}$ of.the $t h$ e rmoc o u p l e s.

The calibration of the furnace-temperature thermocouple was carried out according to the method of FAUST ( 78 ), using the $\alpha \rightarrow \beta$-quartz inversion at $573^{\circ} \mathrm{C}$. The observed variability of this inversion is $1,89^{\circ} \mathrm{C}$, thus lying within the experimental error in reading the furnace temperature line. The e.m.f. of the Pt - Pt $10 \% \mathrm{Rh}$ thermocouple at $573^{\circ} \mathrm{C}$ (cold junction at $9^{\circ} \mathrm{C}$ ) is $4.90 \mathrm{mV}$. The recorded galvanometer-deflection at $573^{\circ} \mathrm{C}$ was accurately the same as the recorded deflection of an applied e.m.f. of $4.90^{\circ} \mathrm{mV}$.

The diffe $r$ e $t$ i a $l$ thermocouple was calibrated empirically with each of the two junctions placed in a waterbath of different temperature, the temperature of which was measured with a precision mercury thermometer. In the graph of fig. 9 the observed magnitude of the galvanometer deflection is plotted against difference temperature. 


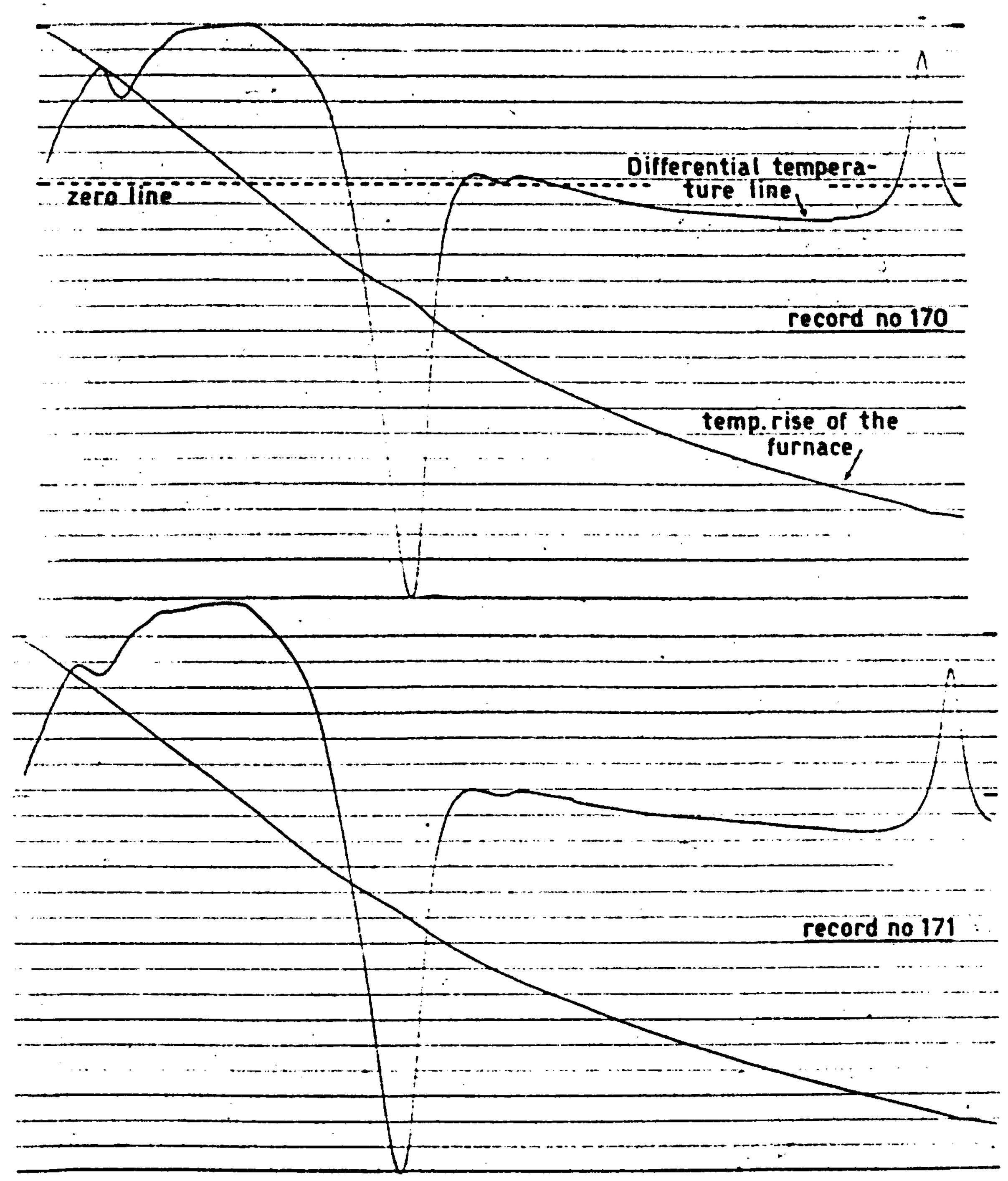

fig. 8. Original duplicate recording of a mixture containing $90 \%$ kaolinite and $10 \%$ montmorillonite. 


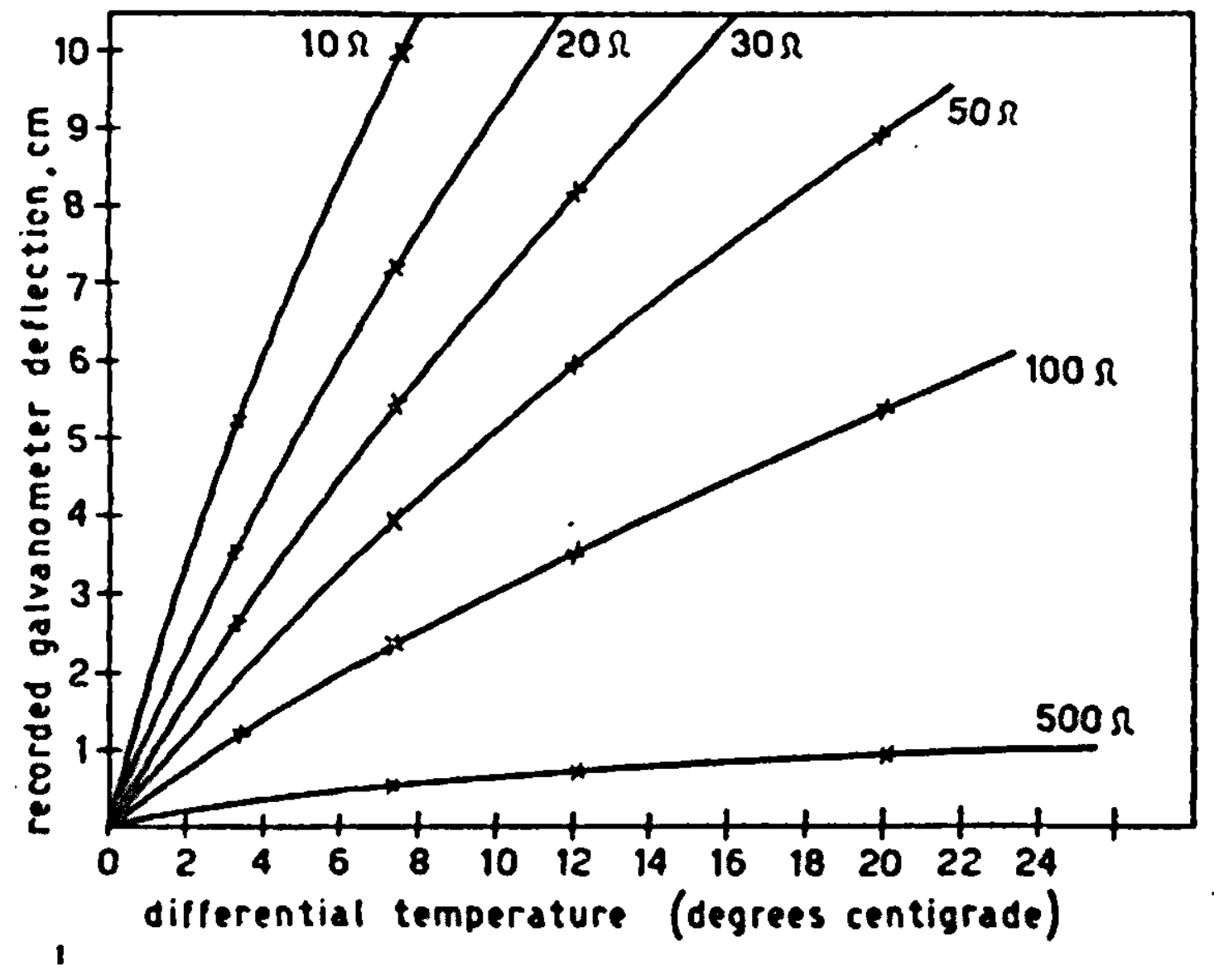

fig. 9. Plot of $\Delta T$ vs. recorded galvanometer deflection (cold junction at $10,5^{\circ} \mathrm{C}$ ), for various sensitivity scales.

It should however be emphasized, that this calibration only holds for the low temperature range. As may be computed from the reference tables $(142,180)$ of the Pt - Pt 10\% Rh thermocouples, the e.m.f. of the differential thermocouple for an observed difference of $20^{\circ}$ in the range $10-30^{\circ} \mathrm{C}$ is $0.11 \mathrm{mV}$, in the range $300-320^{\circ} \mathrm{C} 0.19 \mathrm{mV}$, in the range $1000-1023^{\circ} \mathrm{C} 0,23 \mathrm{mV}$. For accurate difference temperature measurements it is necessary to con-. sider the dependency of $\Delta$ e.m.f. on temperature op to $10000 \mathrm{C}$. I he us e $f u$ I e s $s$ f $t h$ e equipment.

For an appreciation of the usefulness of the equipment the following four items are of interest, viz. sensitivity, accurracy, reliability and practicability.

The sensitivity, expressed as the smallest quantity of any substance detectable in a mixture, is different for the various clay minerals, and has appeared to be strongly dependent on a great number of experimental conditions, as rate of heating, type of sample holder, thermocouple placement and sensitivity scale. The sensitivity may be raised or lowered appreciably by various means as is discussed in chapter 3 .

The accurracy of the method depends in part upon the reading accuracy. With the photographic paper used the accuracy was $(\mathrm{T} \pm 3)^{{ }^{O} \mathrm{C}}$ for the furnace temperature readings. The accurracy of difference temperature readings varied according to the sensitivity scale used, but was always below 1 degree. The reaction temperatures of the different clay minerals mentioned in this study are always given in rounded values, $80573^{\circ} \mathrm{C}$ is given as $575^{\circ} \mathrm{C}, 988^{\circ} \mathrm{C}$ as $990^{\circ} \mathrm{C}$, etc. 
The rellablifty of the apparatus was tested by duplicating and triplicating the curves of various clay samples. In fig. 8 a duplicated result is given of a kaolinite with $10 \%$ admixture of montmorillonite. The duplicability of the results is seen to be almost perfect. Most of the clays were run only one time for routine work. From time to time, however, duplicated analyans were made to check the reliability.

The practicability of the equipment turned out to be a function of various experimental conditions, as will be seen in the following chapter.

The mate ria l.s us ed.

A number of clays was used as standard for checking purposes. Most of these were used in the experiments, described in chapter 3. The identity of these clajs was verified by means of X-ray analysis, for which the writer is indebted to Mr. Drs. P.H.DAI (Keramisch Instituut T.N.O., Gouda) and to Mr. Dr.Ir.van der MAREL (Bodemkundig Instituut T.N.O., Groningen). AlI indications refer to clay separate $(<2 \mu)$.

The standard clays used were the following:

$\mathrm{K}$ a $\circ$ I $\mathrm{n} \perp \mathrm{t} \mathrm{e}$, isle of Banka, Indonesia: obtained from the Keramisch Institunt, Gouda. Pure white, coarse crystalline sample, without admixture. $K a \circ$ I 1 n $i t$, Drybranch, Georgia, U.S.A.: obtalned from Ward's Natural Science Establishment, NewYork City. White, rather coarse crystalline sample, with a slight impurity of montmorillonite. References 152, 174, 245.

$\mathrm{K}$ a 0 I $1 \mathrm{n} 1 \mathrm{t} e$, Les Eyzies, Dordogne, France: obtained from Mrs. S.CAIILERE, Paris. Pure white, coarse crystalline sample without impurities. References: 46.

$\mathrm{K}$ a 0 I 1 n 1 t e, Zettlitz, Tschechoslovakaya; obtained from the Keramisch Instituut, Gouda. Pure white, coarse crystalline sample. Standard kaolinite of the Union de Ia Chimie pure et appliquee. References: 152, 245.

$\mathrm{H}$ a $I$ I $\circ$ g $\mathrm{I} t \mathrm{e}$, (hydrated) Mindesberg, Germany; obtained from Dr H.T.van der MAREI, Groningen. Pure sample, stored in a closed bottle.

H a 1 I $\circ$ y 1 t e, var. Indianaite, Bedford, Indiana U.S.A.; obtained from Tard N.S.E. Partial hydrated sample, pure white. References 6, 247. 
H a $I$ I y s i $t$ e, Djebel Debar, Algeria, N.-Africa; obtained Prom Mrs. S. CAILLERE Paris. X-ray photograph indicates a mixture of kaolinite and hydrated halloysite. References: 46, 91.

$M \circ n t m \circ r i l l o n i t e$, Geisenheim, Germany. Very pure montmorilionite, poor in $\mathrm{Mg}$ and $\mathrm{Ca}$.

$M \circ n t m \circ r i l 1 \circ n i t e$, Osage, Wyoming U.S.A.; obtained from Ward's Natural Science Establihment. Rather pure sample, with some admixture of cristobalite. References: 228, $242,282$.

$M \circ n t m \circ r 1110 \mathrm{n} 1 \mathrm{t}$, , Wyoming U.S.A. Standard sample obtained from City Chem. Corp. New-York. Pure sample, indicated as "Wyoming bentonite."

$M \circ n t$ m o $r i 1$ i $n i t$, Cadouin, Dordogne, France; obtained from Mrs. S. CAILIERE, Paris.. Pure sample with pink colour. References:46,227.

B e 1 d e $I$ I i.t e, Burns, Mississippi.U.S.A.; obtained from Dr. H.W.van der MAREL, Groningen. Pure sample.

$\mathrm{H}$ e c $t$ or $1 \mathrm{t}$ e, Hector, California, U.S.A.; Rather pure sample obtained from Dr. H.W.van der MAREL Groningen. References: 26,88 .

I $I$ I $t$ e, Fithian, Illinois U.S.A.; obtained from Ward's Natural Science Establishment. Purified sample contains small amounts of quartz according to $X$-ray analysis.

I $I$ i $t$ e, Winsum, Groningen, Netherlands; rather pure sample, with small amounts of quartz and montmorilionite.

A $t$ a p u $1 \mathrm{~g} i \mathrm{t}$ e, Attapulgus, Georgia U.S.A.; obtained from Ward's Natural Science Establishment. Rather pure sample. References: $53,76,170,182$.

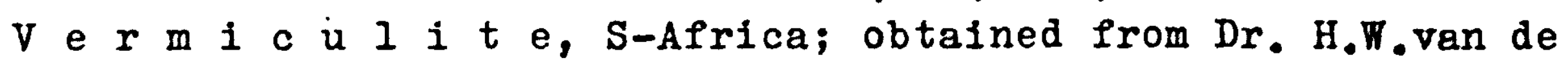
MAREL. Pure sample. References: 15, 143.

Q u a r t $z$, Moneta, Virginia U.S.A.; obtained from Ward's Natural Science Establishment. Very pure sample.

$Q u$ a $r$ t $z$, Germany; Merck's grade. Very pure.

Go e $t h i t e$, Alban-le-Fraysse, France; obtained from Mrs S.CAIILERE, Paris. Very pure sample, coarse crystalline. 
G 1 b b g $1 t$ e, New Caledony, Australia; Very pure, coarse crystalline sample.

$G \perp b$ b $1 t e-K a \circ I 1 n \perp t e$, Mungo, Surinam; obtained Prom Ir. J. VERHOOG, Paramaribo, Dutch Guyana. Mixture of gibbsite and kaolinite, coarse cryatalline. 


\section{AN ACCOUNT OF THE FACTORS WHICH \\ DETERMINE THE SHAPE OF. DTA CURVES}

1. Introduction.

As outlined in chapter 1 , there is much evidence to indicate that a great number of e $x$ p e r i m e $t a 1$ c on $d i t i o n s$ modify the shape of actually recorded curves of one and the same clay sample $(12,46,147,191,219)$. Besides these experimental factors the $n$ a $t$ u $e$ o $t h e$ c i a $y$ is a decisive factor in the observed reactions. Thus in the enumeration of the factors determining the shape of DTA curves we may distinguish between experimental factors and clay factors. The experimental factors are determined by the conditions of the experiment; the clay factors, by the nature of the clay. The several factors acting may be summarized as follows:

1. experimental factors

a. rate of temperature rise of the furnace;

v. nature of the sample holder;

c. depth and radius of the sample holes in the holder;

d. the places of temperature measurement of both furnace temperature and differential temperature;

e. nature and proportions of the thermocouples;

f. the nature of the inert substance (reference material for the differential thermocouple);

g. the tightness of packing of the clay and inert substance in the holes;

h. the effect of covering the sample holes;

i. the composition of the furnace-atmosphere.

2. Clay factors.

j. the particle size and the nature of the clay minerals present;

k. the degree of crystallization;

1. the cations adsorbed;

$\underline{m}$. the presence of admixtures in the clay (salts, etc.).

Fortunately these factors are not all of equal importance. The recorded results are determined primarily by items $a, c, d$, $g, h, i, j$ and $k$. 
In the discussion of the relative influence of the two sets of factors above listed, three aspects of importance in the analysis should be distinguished. These are the influence of the factors upon the peak temperature, upon the reaction range and upon the intensity of the reactions (peak- height-and/or peaksurrace.

The recording mechanism and equipment as a variable factor in the analysia. is lept out of consideration. It is self-evident that amplification of the e.m.f. of the differential thermocouple $(21,177)$ gives rise to an exaggerated picture of the DTA curves. This influence may be corrected easily.

\section{Part I: Experimental factors.}

52. The 1 influence of $t h$ e rate of $t e m-$ perature rise.

HOULDSTORTH and COBB were the first to observe the influence of the velocity of temperature rise upon the measured reaction ranges of kaolinite. The greater the rate of temperature rise, the more the dehydration reaction at about $550^{\circ} \mathrm{C}$ was delayed. The same held for the exothermic reaction at about $980^{\circ}$ C. In accurate static experiments PIETERS (237) observed that the dehydration reaction of kaolinite occured slightly above $430^{\circ} \mathrm{C}$. Static experiments may be considered as having a rate of temperature rise zero. The dehydration curves published by NUTTING (224) indicate that the initiation of the dehydration reaction of kaolinite occurs at an even lower temperature (at about $380^{\circ} \mathrm{C}$ ), the bulk of the $\mathrm{H}_{2} \mathrm{O}$ vanishing at $500-510^{\circ} \mathrm{C}$. These same observations were made by IONGCHAMBON (189). On the other hand, HAMIITON (120) and YURGANOV (285) note the initiation of the reaction as occuring alightly above $400^{\circ} \mathrm{C}$, the bulk of the water vanishing at about $500^{\circ} \mathrm{C}$.

In continuous dehydration experiments, carried out with an automatic recording thermobalance, MERVEILIE and BOUREIIIE (210) and KUNIER (213) confirmed and extended the earlier observations of HOULDSWORTH and COBB. So it is not surprising that in DTA records this same lag of reactions is observed, the delay being more pronounced as the heating rate is increased (DE IEENHEER (187), SPEII (271), ARENS (12)).

$E x p \in r i m e n t s$

In order to evaluate the influence of heating rate upon 
the recording of thermal reactions in DTA, a number of runs were made with the same sample of clay, but submitted to different heating rates in the furnaces I, II and III. For every set of observations the other variables (sampleholder, thermocouples, tightness of packing, etc.) were kept constant. The results are, tabulated in table 2. See al6o fig. 19.

\section{Table 2.}

The influence of the rate of temperature rise of the furnace upon the observed peak temperatures, peak heights, peak ranges and peak areas of some reactions.

\begin{tabular}{|c|c|c|c|c|c|c|c|}
\hline Sample & $\begin{array}{l}\text { observed } \\
\text { reaction }\end{array}$ & $\begin{array}{l}\text { run } \\
\text { no. }\end{array}$ & $\begin{array}{l}\text { rate of } \\
\text { beating } \\
\mathrm{C} / \mathrm{min}^{2}\end{array}$ & $\begin{array}{l}\text { peak } \\
\text { temp } \\
\text { oc } \\
\end{array}$ & $\begin{array}{l}\text { peak } \\
\text { he1ght } \\
\text { me }\end{array}$ & $\begin{array}{l}\text { peak } \\
\text { range } \\
\text { min. }\end{array}$ & $\begin{array}{r}\text { peak } \\
\text { areq } \\
\text { men } 2 \\
\end{array}$ \\
\hline \begin{tabular}{|} 
Kaolinite, \\
Drybranch. \\
Kaolinite, \\
Ranau. \\
\\
Montmorilloni \\
Orage. \\
Halloysite, \\
Mindesberg. \\
Quartz, \\
Moneta.
\end{tabular} & \begin{tabular}{|l} 
dehydration \\
do \\
do \\
do \\
do \\
do \\
do \\
do \\
do \\
inversion \\
do \\
do \\
te dehydrat. \\
do \\
do \\
do \\
do \\
inversion \\
do \\
do \\
do
\end{tabular} & $\begin{array}{l}100 \\
124 \\
171 \\
135 \\
157 \\
128 \\
127 \\
202 \\
193 \\
128 \\
202 \\
193 \\
118 \\
136 \\
22 \\
466 \\
467 \\
32 \\
116 \\
143 \\
225\end{array}$ & $\begin{array}{r}6 \\
10 \\
14 \\
16 \\
19 \\
9 \\
12 \\
19 \\
22 \\
4 \\
6 \\
11 \\
6 \\
14 \\
17 \\
15 \\
29 \\
6 \\
12 \\
18 \\
21\end{array}$ & $\begin{array}{l}545 \\
\cdot \\
580 \\
600 \\
610 \\
620 \\
565 \\
570 \\
590 \\
595 \\
970 \\
975 \\
975 \\
685 \\
700 \\
710 \\
580 \\
610 \\
575 \\
575 \\
575 \\
575\end{array}$ & $\begin{array}{r}18 \\
41 \\
41 \\
82 \\
86 \\
96 \\
20 \\
26 \\
70 \\
85 \\
8 \\
20 \\
28 \\
8 \\
19 \\
23 \\
36 \\
70 \\
3 \\
5 \\
8 \\
12\end{array}$ & $\begin{array}{l}14.0 \\
12.0 \\
11.0 \\
10.2 \\
10.0 \\
12.0 \\
10.0 \\
9.2 \\
9.2 \\
8.4 \\
7.2 \\
6.0 \\
12.8 \\
6.8 \\
5.2 \\
9.2 \\
4.8 \\
0.8 \\
0.5 \\
0.4 \\
0.5\end{array}$ & $\begin{array}{r}630 \\
1230 \\
- \\
2064 \\
2400 \\
600 \\
680 \\
1610 \\
1955 \\
168 \\
360 \\
420 \\
256 \\
323 \\
300 \\
820 \\
850 \\
7 \\
10 \\
26 \\
36\end{array}$ \\
\hline
\end{tabular}

It appears that considerable peak shifting occurs as a consequence of steeper heating ratea. One should note here that measurements of the furnace temperatures were made in the clay sample itself, so that the reported peak temperatures refer to the temperature of the clay. The influence of measuring the furnace temperature in the inert substance will be discussed below in this same chapter; in these cases peak ohifting is observed, 
- amounting to about 90 degrees centigrade.

From the data it appearg (see alai fig. 19) that the heights of the peaks also depend on the velocity of temperature rise, steep heating rates being correlated with huge peaks. Furthermore the time of reaction, indicated as the peak range in the table, is also subject to variation, steep heating rates being correluted with small peak ranges. The peak range, however, may be expressed not only as the time of reaction but also as the difference between the temperatare of expiration and the temperature of initiation. One sees that the temperature of $1-$ nitiation is lowered when the heating rate is lowered and the same holds, though to a lesser extent, for the temperature of expiration of the reaction.

The peak areas in different experiments with the same clay sample do not have a constant value, as appears from the figurea. The present findings thus contrast with the observations of BERKELHAMER and SPEII (26) and with the theoretical derivation of KULP. and $\operatorname{KERR}(174,176)$. These workers used rather small variations in heating rates. One more interesting point follows from the data given and that 18 the constancy of the $\alpha \rightarrow \beta$-quartz inversion at $573^{\circ} \mathrm{C}$. This reaction, because of 1 ts exceedingly rapid expiration and its accurate reproducibility, may be used as standard for calibration of the thermometer scale (BATES and PHELPS, 18); as has been described previously. If however the furnace temperature is measured in the inert substance, one may find as for instance KULP and KERR (177) did, a delay of this reaction. One should recognize that this delay is only apparent; it is caused by differences in heat flow in the inert aubstance and the reactant.

The peak temperature of the exothermal reaction of kaolinites at about $950^{\circ} \mathrm{C}$ is not noticeably affected by the heating rate, but the peak height, peak range and peak area are affeoted. However, a.rather great varietal difference is observed in the appearance of this reaction if different kaolinites are compared. It is suggested below in this chapter that these differences may be accribed to differences in the degree of crystallization (see also fig. 22).

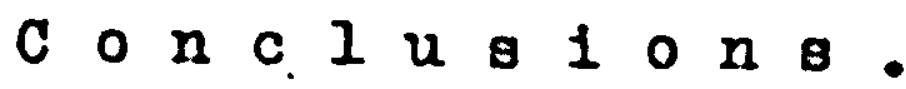

The effect of the rate of temperature rise upon the observed reactions in DTA may be summarized as follons:

1. There exista. a syatematic difference between the reactions 
accompanied by $20 s$ s in weight and those not accompanied by it; 2. Types of reactions accompanied by a loss in weight are strongly influenced by the heating rate; with increasing heating rate the peak temperature increases, as do also the peak height and peak area. But the peak range, measured as the time of reaction, decreases;

3. If the furnace temperature is measured in the clay sample types of reactions in which there is no 108 s in weight are not affected as regarda peak temperature, but are affected as regards peak height, range and area;

4. From the results of experiments with varying heating rate, all other factors being kept constant, it is posgible to compute empirically the reaction temperatures for zero rate of heating (static dehydration etc.). These "assymptotic" reaction temperatures are of importance for correlating DTA with dehydration curves.

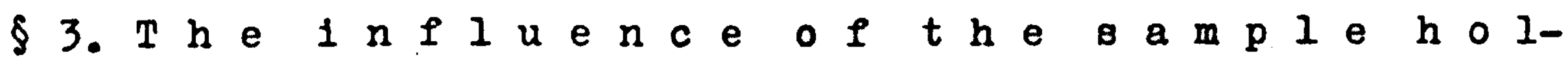
d.e $\mathbf{r}$.

Iittle is known of the effect of the nature of the sample holder upon the recorded DTA result, though, at least from a theoretical point of view, considerable influence might be expected. As all workers in this field use different types of sample holders there reaults considerable confusion.

Sample blocks differ among themselves in weight and specific heat, also in heat conductivity and in heat transfer coefficients. The greater the heat conductivity and heat trangfer coefficient, the more rapid will be the calorie transport to the reactant during an endothermic reaction. As a consequence temperature gradients in the sample holder and between the wall of the sample hole and the place of temperature measurement will be minimized. Though the influence of heat transfer from block to reactants during any reaction has been recognized theoretically (VOLD, 276) never a comparison has been made between different containers.

Experiments.

In order to evaluate the influence of the nature of the sample holder, experiments were carried out with the sample blocks, $c, d, g$ and $j$, keeping all other variables constant. In fig. 10 some curves are reproduced, obtained with the same clay material but submitted to the analysis in different blocks. 
$I=$ NICKEL-BLOCK II = CERAMIC -BLOCK

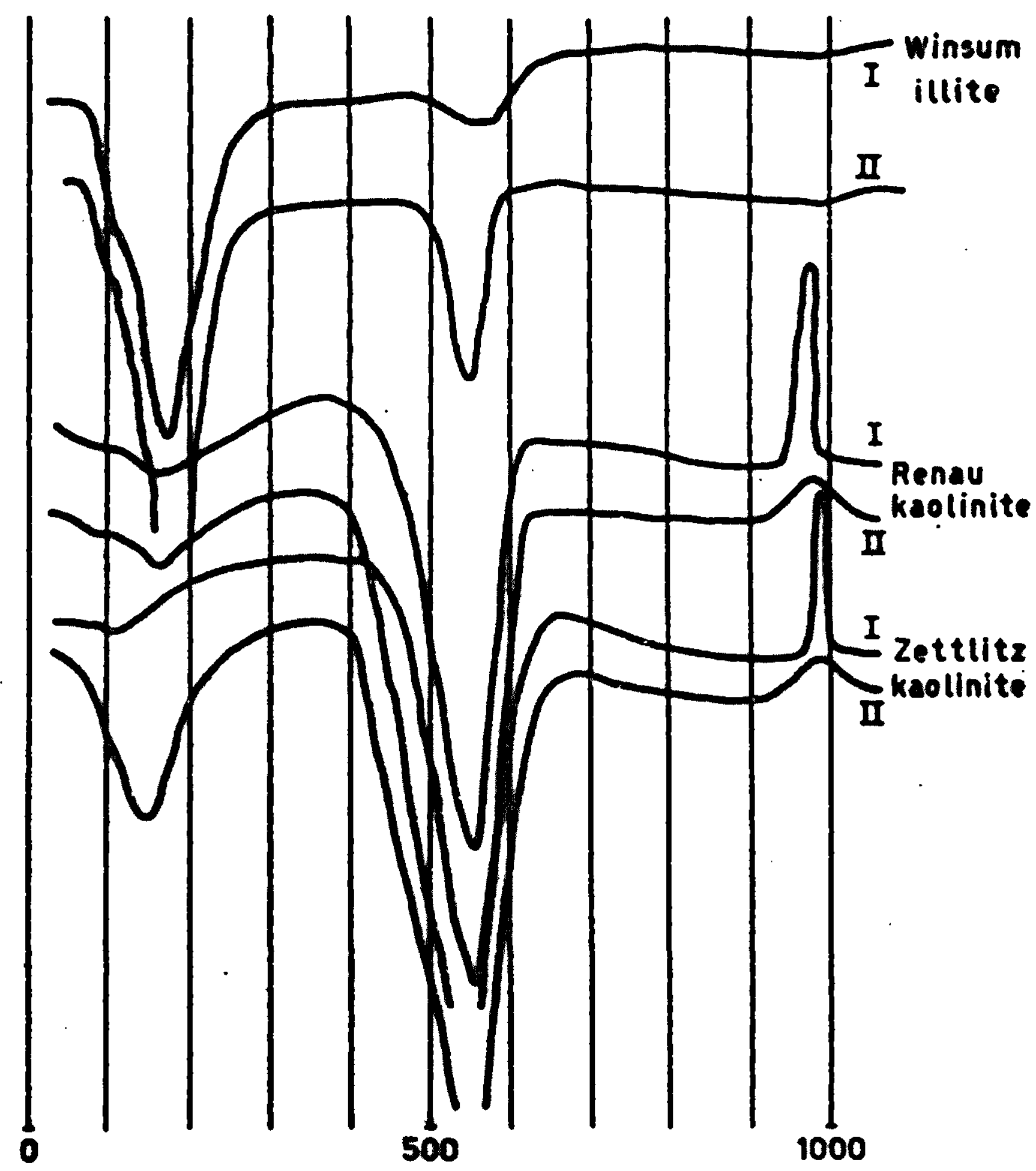

Fig. 10. The influence of the nature of the sample holder upon some DTA records.

The nickel blocks used has large heat conductivity coefficients and heat transfer coefficients as compared with the ceramic blocks. Some pertinent data for the materials in question follow: heat conductivity of nickel: $\lambda=0.142 \mathrm{cal} \mathrm{sec}^{-1} \mathrm{~cm}^{-1}$ degree $\mathrm{C}^{-1}$ at room temperature, and $\lambda=0.068 \mathrm{cal} \mathrm{sec}^{-1} \mathrm{~cm}^{-1}$ degree $\mathrm{C}^{-1}$ at $800^{\circ} \mathrm{C}$; heat conductivity of alundum: $\lambda=0.0022$ cal $\mathrm{sec}^{-1} \mathrm{~cm}^{-1}$ degree $\mathrm{c}^{-1}$ at room temperature and $\lambda=0.0011 \mathrm{cal}$ sec $^{-1} \mathrm{~cm}^{-1}$ degree $\mathrm{C}^{-1}$ at $800^{\circ} \mathrm{C}$. These values were computed frop HODGMAN (142) and LANGE (180).

From the curves given in fig. 10 it appears that ceramic blocks give rise to curves with relative sharp endothermic and faint exothermic reactions, while the opposite holds for nickel blocks. Thus it may be adrantageous to use nickel blocks in cases, where weak exothermic phenomena are expected (hydrous iron oxydes), whereas ceramic blocks might be preferred in the case of clays exhibiting weak endothermal reactions (illites e.g.). 
C $\circ \mathrm{n}$ c $l u$ s $1 \circ \mathrm{n} \mathrm{s}$.

From these and other observations the following conclusions were drawn.

1. Nickel blocks yield DTA curves with relatively flat endothermal and sharp exothermal reactions.

2. Ceramic blocks yield curves with sharp endothermal and relatively flat exothermal reactions.

3. All types of reactions undergo influences of the sample holder, irrespective of whether the reactions are accompanied by loss of material or not.

4. No noticeable peak shifting is observed.

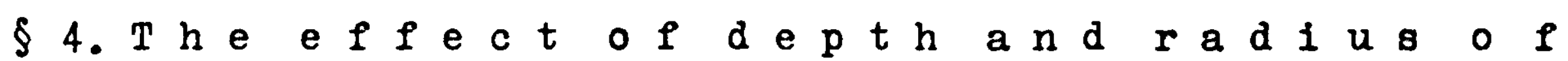
$t h e$ s a m I e hol.es.

This factor refers to a certain extent to the mass of clay material, taking part in the experiment, as it is determined by the volume $V$ of the hole

$$
\mathrm{M}=\rho \mathrm{V}=\pi \mathrm{r}^{2} \mathrm{~h} \rho
$$

where $M$ is the mass of clay material present, $\rho$ is the apparent specific weight, $r=$ radius and $h=$ depth of the sample hole.

The volume $V$ however appears to be a factor of minor importance, as regards reactions accompanied by changes in weight. The duration of any such reaction is preponderately determined by the velocity of escape of the originating gas $\left(\mathrm{H}_{2} \mathrm{O}, \mathrm{CO}_{2}\right)$ or of the entering gas ( $\mathrm{O}_{2}$ in the case of oxydation reactions). That the velocity of the gas stream is obviously affected by the depth and radius of the sample hole may be demonstrated for the decomposition of carbonates $(150,151,286,287)$. Huge endothermic reaction-records may be obtained, if the escape of originating gas is inhibited by sample containers having relative great depth compared to the radius. In such containers oxidation reactions (e.g. $4 \mathrm{FeO}+\mathrm{O}_{2} \rightarrow 2 \mathrm{Fe}_{2} \mathrm{O}_{3}$ ) may be strongly inhibited, so that they are hardly observable. The unexplained behaviour of siderite $\left(\mathrm{FeCO}_{3}\right)$ and rhodochrosite $\left(\mathrm{MnCO}_{3}\right)$ in DTA records (BECK, 22; SPEII, 271; KERR and KULP, 173; FREDERICKSON 89; CUTHBERT and ROTLAND, 61) probably is caused by mutual differences in depth and radius of the sample holes used. Unfortunately a number of investigators have failed to describe the sample blocks they used. The workers, who have operated with sample holes of relative small depth compared to radius have obtained the best records of the ferro-ferri reaction in siderite at about $730^{\circ} \mathrm{C}$. 
Exp e r 1 m e $n$ t

In order to study the influence of depth and radius of the sample holes, a number of rung were made with nickel-blocks ( $a$, $b, c, d$ and e) oupplied with the same quantity of clay, all other variables being kept as constant as possible. The results of these experiments are given in table 3. It appears that in reactiong accompanied by changes in weight, peak temperature, peak height and total duration of reactions are affected by varying radius and depth of the sample holes.

Table 3

The effect of depth and radius of the sample holes upon some curve characteristica.

\begin{tabular}{|c|c|c|c|c|c|c|c|c|}
\hline Sample & $\begin{array}{l}\text { Run } \\
\text { no. }\end{array}$ & $\begin{array}{l}\mathbf{x} \\
\mathrm{mm}\end{array}$ & $\begin{array}{r}\mathrm{h} \\
\mathrm{mm}\end{array}$ & $\begin{array}{l}\text { sample } \\
\text { weight } \\
\text { gr. }\end{array}$ & $\begin{array}{l}\text { observed } \\
\text { reaction }\end{array}$ & $\begin{array}{l}\text { peak } \\
\text { temp. } \\
\text { oc } .\end{array}$ & $\begin{array}{l}\text { peak } \\
\text { height } \\
\mathrm{mm}\end{array}$ & $\begin{array}{l}\text { peak } \\
\text { range } \\
\text { min. }\end{array}$ \\
\hline $\begin{array}{l}\text { Kaolinite, } \\
\text { Banka. } \\
\text { Kaolinite, } \\
\text { Zettlitz. } \\
\text { Quartz, } \\
\text { Merck. } \\
\text { Halloysite, } \\
\text { Djebel Debar. }\end{array}$ & $\begin{array}{r}219 \\
45 \\
260 \\
159 \\
281 \\
174 \\
179 \\
145 \\
180 \\
74 \\
109 \\
211 \\
59\end{array}$ & $\begin{array}{r}3 \\
5 \\
6 \\
8 \\
8 \\
11 \\
3 \\
5 \\
6 \\
8 \\
6 \\
8 \\
10\end{array}$ & $\begin{array}{r}12 \\
9 \\
12 \\
12 \\
12 \\
12 \\
12 \\
9 \\
12 \\
12 \\
6 \\
12 \\
15\end{array}$ & $\begin{array}{l}0.080 \\
0.120 \\
0.120 \\
0.120 \\
0.150 \\
0.150 \\
0.050 \\
0.050 \\
0.050 \\
0.050 \\
0.120 \\
0.120 \\
0.120\end{array}$ & $\begin{array}{c}\text { dehydr. } \\
\text { do } \\
\text { do } \\
\text { do } \\
\text { do } \\
\text { do } \\
\text { inversion } \\
\text { do } \\
\text { do } \\
\text { do } \\
\text { do } \\
\text { do } \\
\text { do }\end{array}$ & $\begin{array}{l}555 \\
580 \\
585 \\
605 \\
575 \\
595 \\
575 \\
575 \\
575 \\
575 \\
980 \\
985 \\
985\end{array}$ & $\begin{array}{r}52 \\
42 \\
70 \\
62 \\
74 \\
52 \\
4 \\
3 \\
4 \\
6 \\
5 \\
7 \\
11\end{array}$ & $\begin{array}{r}8.6 \\
9.2 \\
9.0 \\
9.0 \\
12.0 \\
12.2 \\
0.4 \\
0.4 \\
0.4 \\
0.4 \\
0.9 \\
1.0 \\
1.0\end{array}$ \\
\hline
\end{tabular}

It appears from the data in table 3 that it is often advantageous to work with sample blocks supplied with deep and narrow holes, as for instance when making runs with micaceous materials, having small lattice water contents. Although the dehydration reactions may be enhanced in such cases, one should clearly realize that in these same runs certain other reactions may be overlooked. It is therefore advisable to run the same material succesively in different omple holders, to be sure that no reation 18 overlooked.

C 0 n c 1 u

From these and other data the following conclusions seem justified:

1. The depth and radius of sample holes greatly affect the appearance of thermal reactions accompanied by changes in weight, as regarde peak temperature, peak helght and total 
duration of reaction.

2. Reactions not accompanied by changes in weight are not affected as regards peak temperature, and only slightly as regards peak height.

3. It is possible to mask or to enhance reactions, by varying the depth and radius of the sample holes.

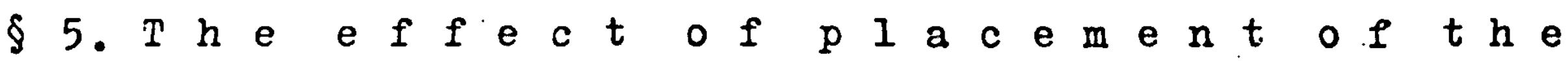

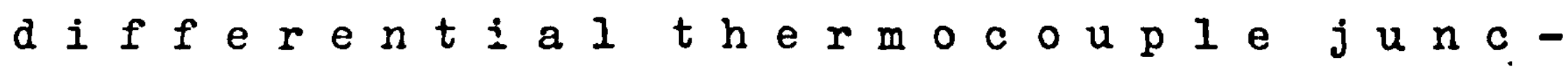
$t i \circ n s$ in $t h e$ c lay-and ine $t$ a a mp 1 e.

Closely related to the factor just discussed is the effect of placement of the thermocouple junctions in the respective materials. No systematic attempt has been made to reveal fully the effect, but in some experiments experience was obtained of its approximate magnitude. The effect in the low temperature range is different from the effect in the high temperature range. One remembers here that in the low temperature range heat transfer occurs largely by conduction, in the high temperature range by radiation. In general the following conclusions seem warranted

1. Deep placement of the differential thermocouple junctions in the samples yields DTA curves with relatively strong endothermic reactions in the low temperature ranges and flat endothermic reactions in the high ranges.

2. Exothermic reactions (in the high temperature range) are recorded the best with deep placement of the differential thermocouple.

3. For most reactions the thermocouple should be inserted in the samples without protective cover.

4. Thermocouples, fixed in the sample holders, are a great advantage as regards reproducibility of data.

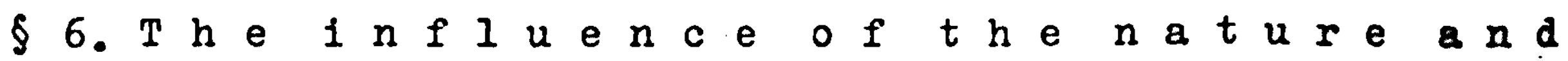
p r o p o r t i $\circ$ s of $t h$ e $t h$ e r o c o u p 1 e $\mathbf{s}$.

In the literature various types of thermocouples have been described. Most European workers operate with Pt - Pt $10 \% \mathrm{Bh}$ thermocouples (CAILLERE and HENIN, MUNIER, RAEGEMNNS, IEPINGIE, ROBERTS $a_{.0}$ ). These thermocouples are preferred on account of their durability. A disadvantage however is the relatively 
small e.m.f. being $9.57 \mathrm{mV}$ at $1000^{\circ} \mathrm{C}$ (cold junction at $0^{\circ} \mathrm{C}$ ). Therefore, in order to obviate the use of sensitive galvanometers for the differential temperature records, many American workers prefer the use of chromel-alumel thermocouples. These have an e.m.f. of $41.31 \mathrm{mV}$ at $1000^{\circ} \mathrm{C}$ (KUIP and KERR, JEFFRIES a.0.). The use of iron-constantan thermocouples, though having

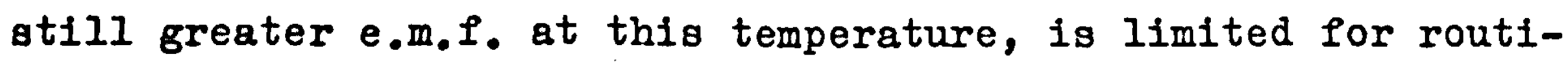
ne work because of orydation.

In the present study only Pt - Pt 10\% Rh thermocouples have been used, but with varying wire diameters, viz. $0.2 \mathrm{~mm}$ and $0.5 \mathrm{~mm}$. These sizes are in the range normally used. The heat capacity of the inserted wire was always small in comparison with the heat capacity of the clay $\left(8 \times 10^{-4}\right.$ cal va $4 \times 10^{-2}$ cal for the $0.2 \mathrm{~mm}$ wire diameter). Although the differences obtained in the present records were only of minor importance, it is noted that WEB (unpublished results) obtained rather astonishing differences in recorded curves, obtained with various wire diameters, according to a personal communication of $\mathrm{Dr}$ S.B.HENDRICKS. The effect of wire diameter is expected to be great, when wire diameter is large in proportion to sample hole diameter, or when the heat capacity of inserted wire is great in proportion to the heat capacity of the clay sample and inert sample.

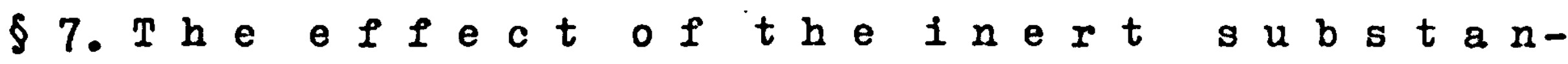 c e}

The inert material is as important for satisfactory DTA records as the clay material itself. Many different types of inert material are in use. Most workers use calcined alumina $\left(\mathrm{Al}_{2} \mathrm{O}_{3}\right)$. British workers in this field (MACKENZIE, ROBERTS), and oome French workers (e.g. MUNIER, LEPINGIE) prefer the use of fired clay, from the same sample as is to be investigated, as inert material. Both types of inert material have advantages and disadrantages.

The first requirement for any inert material is that it really be inert. That is to say, no reaction whatsoever may occur during heating. If calcined alumina is ujed in a number of successive experiments without replacement, it becomes more or less hybroscoplo, depending on partiole size. Since hygrospopicity of the inert substance may give the impression of an exothermal reaction in the clay sample in DTA records, the implication is that the calcined alumina should be replaced after 
each run, or at least after each two runs.

For satiofactory results the particle size distribution of the inert material should be approximately the same as in the clay sample. In some places rather coarse inert material is in use. The consequence is that there exists too big a difference in the contact heat conductivity between the clay and reference sample. This difference is the cause of considerable difficulty in obtaining a straight zero line.

Even the use of calcined clay prepared from the same sample being investigated is not without defects. For example, if the clay contains components with reversible thermal reactions, as for instance quartz, the appearance of such reversible reaction in the clay sample may be fully concealed. Moreover: it is not at all true that calcined clay has the same thermal properties (specific heat, heat conductivity, thermal diffusivity) as the original sample. Some thermal properties for kaolinite and calcined kaolinite $\left(1000^{\circ} \mathrm{C}\right)$ are given in table 4.

Table 4.

Comparison of some thermal properties of kaolinite and calcined kaolinite.

\begin{tabular}{|l|c|c|c|}
\hline & $\begin{array}{l}\text { spec. heat } \\
\text { cal } \mathrm{gr}^{-10} \mathrm{C}^{-1}\end{array}$ & $\begin{array}{c}\text { heat conduct. } \\
\mathrm{cal} \mathrm{cm}^{0} \mathrm{C}^{-1} \mathrm{gec}^{-1}\end{array}$ & $\begin{array}{c}\text { thermal } \\
\text { diffusivity } \\
\mathrm{cm}^{2} \mathrm{gec}^{-1}\end{array}$ \\
\hline kaolinite & 0.201 & $0.72 \cdot 10^{-3}$ & \\
calcined kaolinite & 0.428 & $1.6 \cdot 10^{-3}$ & \\
\hline
\end{tabular}

It appears from the data in table 4 that on thermal evidence alone one is not warranted in using calcined clay as inert material. The only advantage 1s that particle size diatribution of both clay and inert substance is approximately the same.

Another aspect, which should be considered under this heading, is the place where the furnace temperature is to be measured. In most experiments described in the literature furnace temperature is measured in the inert material and not in the clay, this being the cause of rather congiderable ohifts in peak temperatures.

MACKENZIE (191) pointed out that temperatures measured in inert materials should be corrected to clay temperatures in order to facilitate calculations. In order to avoid complications, however, it would appear preferable to measure the furnace tem- 
perature always in the clay sample itself.

$E \times p$ e 1 i e $n t s$.

In this study a number of runs were made, with the furnace temperature thermocouple placed in the inert sample (normally the furnace temperature was measured in the clay). Morecver different types of inert material were used. In one blank experiment with calcined alumina from a foreign source, a rather sharp endothermic reaction at about $220^{\circ} \mathrm{C}$ was observed, indicating the presence of some hydrous Al-oxyde. It is absolutely neccessary to test the inertia of the reference material after each renewal.

The influence of the measurement of furnace temperature in the inert substance upon the peak temperature of some reactions is summarized in table 5. From the figures given it appears that all types of reactions undergo peak shifting when furnace temperature measurements are made in the reference material. The amount of peak shifting, however, is different for the various materials.

\section{Table 5}

Apparent peak shifting as a result of measuring the furnace temperature in the inert substance.

\begin{tabular}{|c|c|c|c|c|c|}
\hline \multirow{2}{*}{ Sample } & \multirow{2}{*}{$\begin{array}{l}\text { Sample } \\
\text { holder }\end{array}$} & \multirow{2}{*}{$\begin{array}{c}\text { heating } \\
\text { rate } \\
\mathrm{c} / \mathrm{min}\end{array}$} & \multicolumn{2}{|c|}{ Peak temperature ${ }^{\circ} \mathrm{C}$} & \multirow{2}{*}{$\begin{array}{l}\text { Difference } \\
\text { (peak shift.) }\end{array}$} \\
\hline & & & $\begin{array}{l}\text { measured } \\
\text { in clay }\end{array}$ & $\begin{array}{c}\text { measured } \\
\text { in inert mat }\end{array}$ & \\
\hline \multirow{2}{*}{$\begin{array}{l}\text { Kaolinite, } \\
\text { Drybranch }\end{array}$} & d & 6 & 540 & 545 & 5 \\
\hline & $\begin{array}{l}d \\
d \\
d \\
d \\
d \\
d \\
d \\
d \\
d\end{array}$ & $\begin{array}{r}14 \\
19 \\
7 \\
12 \\
21 \\
6 \\
12 \\
18 \\
21\end{array}$ & $\begin{array}{l}550 \\
555 \\
560 \\
565 \\
570 \\
575 \\
575 \\
575 \\
575\end{array}$ & $\begin{array}{l}600 \\
620 \\
560 \\
580 \\
605 \\
575 \\
585 \\
590 \\
600\end{array}$ & $\begin{array}{r}50 \\
65 \\
0 \\
15 \\
35 \\
0 \\
10 \\
15 \\
25\end{array}$ \\
\hline
\end{tabular}

The peak shifting observed may be explained qualitatively by mutual differences in thermal conductivity of clay and inert material.

C O n c I u s 1 ons.

The following conclusions may be drawn.

1. The inert material should have thermal characteristics (spec. heat, heat conductivity, thermal diffusivity) as 
closely equal as possible to those of the clay. This requirement is never fully realizable, because the thermal characteristics of clay undergo rather sudden changes, abcompanied with the raactions.

2. If furnace temperature is measured in the inert substance an apparent peak shifting is observed, the amount of which is increased with increasing radius of sample hole and increasing heating rate. This holds for all types of reactions.

3. It is recommended that furnace temperature be measured in the clay sample.

4. The use of calcined clay, of the same sample as is to be investigated, as inert material, has no fundamental advantages over the use of calcined alumina, provided particle size distribution of the latter is not different from the clay.

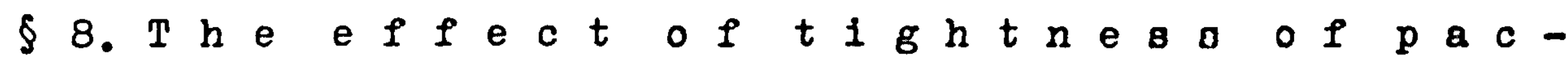
$k i n g$ of c l a y and ine $r t$ a u b $t$ ance in $t h$ e s a m 1 e holes.

The evaluation of the effect of packing on DTA recordings is rather difficult, though the effect itself is obvious. It is not easy to get reproduceable loose packings and this is the reason that very hard packing, or very loose packing (obtained with loose sprinkling of the materials in the respective holes) are most commonly used.

The effect of packing may be reduced to three causes: differences in sample weights, in heat conductivity and in thermal diffusivity. In the low temperature ranges, where heat transfer is governed principally by conduction, the effect is the most pronounced. In the high temperature ranges the effect may fully disappear as heat transfer is there determined principally by radiation.

Ex p e r i m e n t $s$.

A number of experiments were made with different types of packing of clay and inert substance in the sample holes (fig. 11), while all other factors (sample holder, weight of sample etc.) were kept as constant as possible.

In experiments with loose packing (relative great porosity), the heat transfer from the sample block to the thermocouples in the middle of the holes, is inhibited, because of the ve- 
ry small heat conductivity coefficient of the air enclosed. As a result one finds in the recordings endothermic reactions, which are faint compared with those observed for tight packings. The effect on exothermic reactions is in the same direction, though the effect is less pronounced.

The most marked differences originate, if clay sample and inert aample are packed differently. If the clay is packed tightly and the reference material very loosely, one may find an "exothermic" deviation from the zero line of the differential temperature recording galvanometer. The deviation is of unpronounced character and over a rather wide temperature range (see curve 207 in fig. 11). This same effect may be obtained if inert material with a very low coefficient of heat conductivity is used. The opposite effect, an "endothermic" deviation of the differential temperature line over a wide temperature range (up to about $600^{\circ} \mathrm{C}$ ), may be observed if the clay is sprinkled 100sely in the sample hole while the inert substance is packed tightly (see curves 198, 197 and 202). In fig. 11 some pronounced examples of these effects are given.

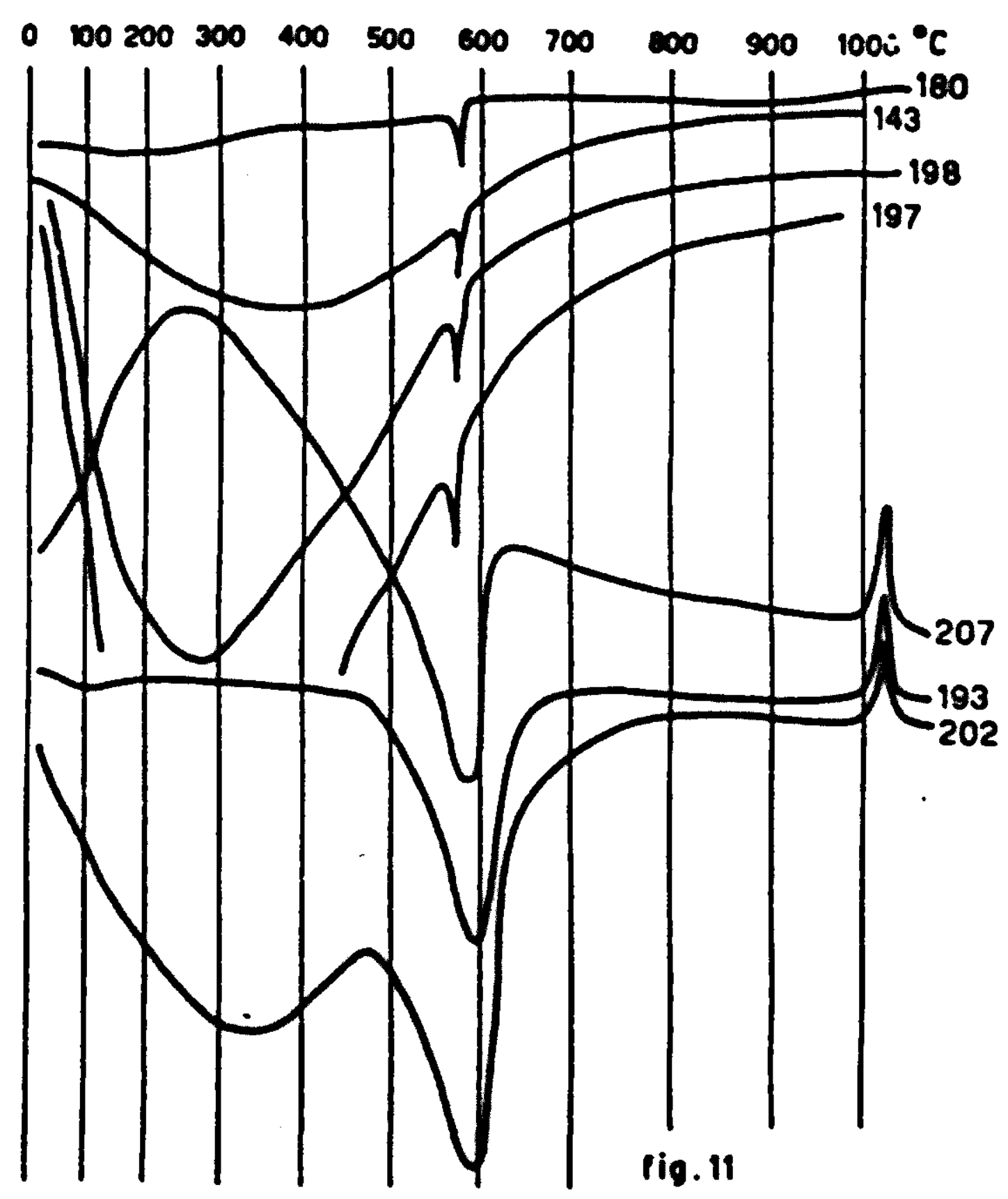

The influence of tightness of packing upon DTA records. Runs no. 143,180,197 and 198: quartz, Moneta, Virginia. Runs no. 193, 202, 207: kaolinite, Ranau, Sumatra. 
C $\circ$ n $\circ 1$ u $81 \circ \mathrm{n}$ s.

The following conclusions may be drawn.

1. Differences in density of packing are the most common cause of deviations from straight zero-lines in ranges where no reactions occur.

2. Hard packing, since it is the easiest to reproduce, is recommended for most cases, to obtain recordings with pronounced reactions and with straight zero lines.

3. Loose packing gives rise to faint reactions, the effect lying in the same direction for all types of reaction, except probably the oxydation reactions.

§9. $\mathrm{Th}$ e e 1 fect of covering the s a p 1 e $h \circ 1$ e 8 .

Covering of sample holes is often desired to avoid direct radiation into the samples, as an aid to get straight zero 1ines.

The covering however influences: the composition of the gaseous phase in the reaction environment. All reactions of the type

and

$\underset{\text { solid }}{\mathrm{AB}} \rightarrow \underset{\text { solid }}{\mathrm{A}}+\underset{\text { gas }}{\mathrm{B}}$

$\underset{\text { solid }}{\mathrm{R}}+\underset{\text { gas }}{\mathrm{O}_{2}} \rightarrow \underset{\text { solid }}{\mathrm{RO}}$

are to a certain extent equilibrium-reactians; hence their expiration is greatly determined by the rate of escape of the formed gas, or by the rate of entrance of the reacting gas.

The first type of reaction is inhibited by covering, the reaction temperature being then strongly shifted upwards; the second type of reaction is not perceptible at all in DTA records, if the reaction vessel is covered. The quantitative evaluation, however, of the peak shifting in the first type of reactions is hardly possible.

Reactions of the type

$$
A \rightarrow A^{\prime}
$$

solid solid

are not materially influenced by covering, as regards peak temperature and intensity of the reactions. 
Experiments.

In furnace III a number of runs were made with the same nickel block, to compare the effect of covering and uncovering.

In fig. 12 some results are given. It is seen that the dehydration reactions are enhanced by covering whereas inversion reactions are not affected.

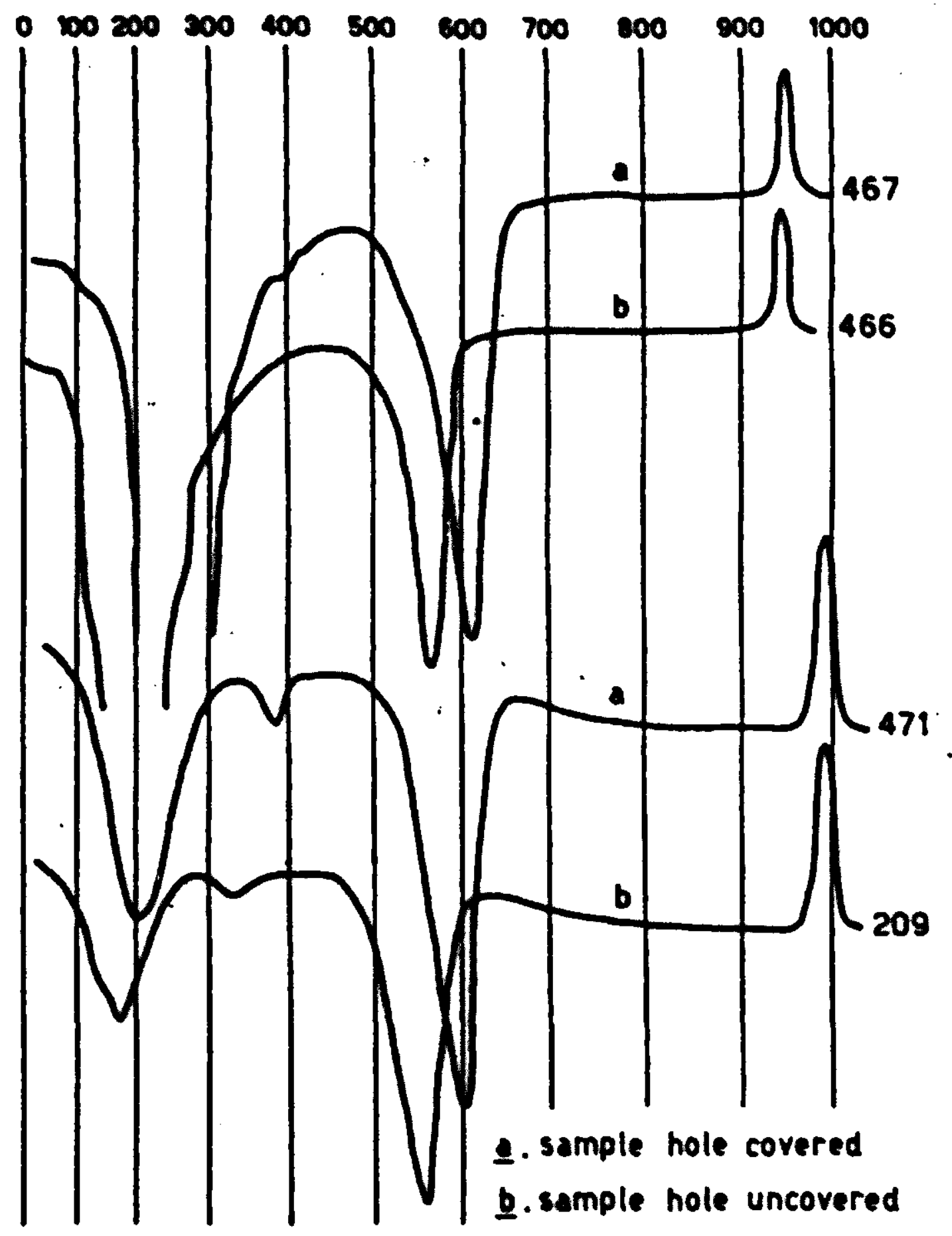

iig. 12

Runs of halloysite, Mindesberg, Germany (no, 466,467) and of indianaite, Bedford, Indiana U.S.A. (no. 471 and 209).

It has been previously indicated in this chapter that the appearance of the oxidation reaction in siderite $\left(\mathrm{FeCO}_{3}\right)$ may be strongly affected by depth and radius of the sample holes. BECK (22) showed that covering of the sample holes could have the same effects. For clays, in which oxidation phenomena are expected upon heating, there should be a liberal acces of oxygen.

In the case of the DTA of siderite and rhodochrosite there is a dilemma. The reaction takes place in two ateps: 


$$
\begin{aligned}
& \mathrm{FeCO}_{3} \\
& 4 \mathrm{FeO}+\mathrm{O}_{2} \rightarrow 2 \mathrm{Fe}_{2} \mathrm{O}_{3}
\end{aligned}
$$

The first mentioned reaction may be enhanced by covering the sample hole. Then reaction peaks occur at higher temperatures. The second reaction may be fully masked by covering. Nith uncovered sampleholes, on the contrary, the first reaction appears less pronounced, while the second is well developped. It is more or less a matter of personal choice and other exper1mental conditions, which reaction should be favoured.

$\checkmark$ o n c 1 u s i $\circ$ n s.

1. Covering the sample holes excert considerable influence upon the appearance of reactions, when there is a change in weight of the reactant.

2. Reactions, accompanied by $10 \mathrm{~s} s$ in weight (dehydration, loos of $\mathrm{CO}_{2}$ ) may be enhanced by covering, while a peakshifting upwards occurs.

3. Reactions accompanied by $g$ a $i n$ in weight (oxidation), may be fully inhibited by covering, or may be of a fully uroronounced character.

4. Though covering may ald in certain cases to obtain straight zero lines, it should be avoided for generel prospecting purposes.

§ 10. The influence of $t h e$ composition of $t h$ e $f u r n$ a c a $\cos$ o $\mathrm{ph}$ e e.

In the same way as covering of the sample holes affects the appearance of thermal reactions, the composition of the furnace atmosphere excerts its influence. Generally this factor is overlooked in the carrying out of dehydration- or of other thermal experiments.

For the dehydration reaction of kaolinite, PIETERS examined very accurately, in a number of static experiments, the influence of the partial vapour pressure of water in the furnace atmosphere upon the reaction temperature. His result are fiven in fig. 13. It is aeen that the temperature of the dehydration reaction increases. with increasing partial vapour pressure of water on the furnace atmosphere. 


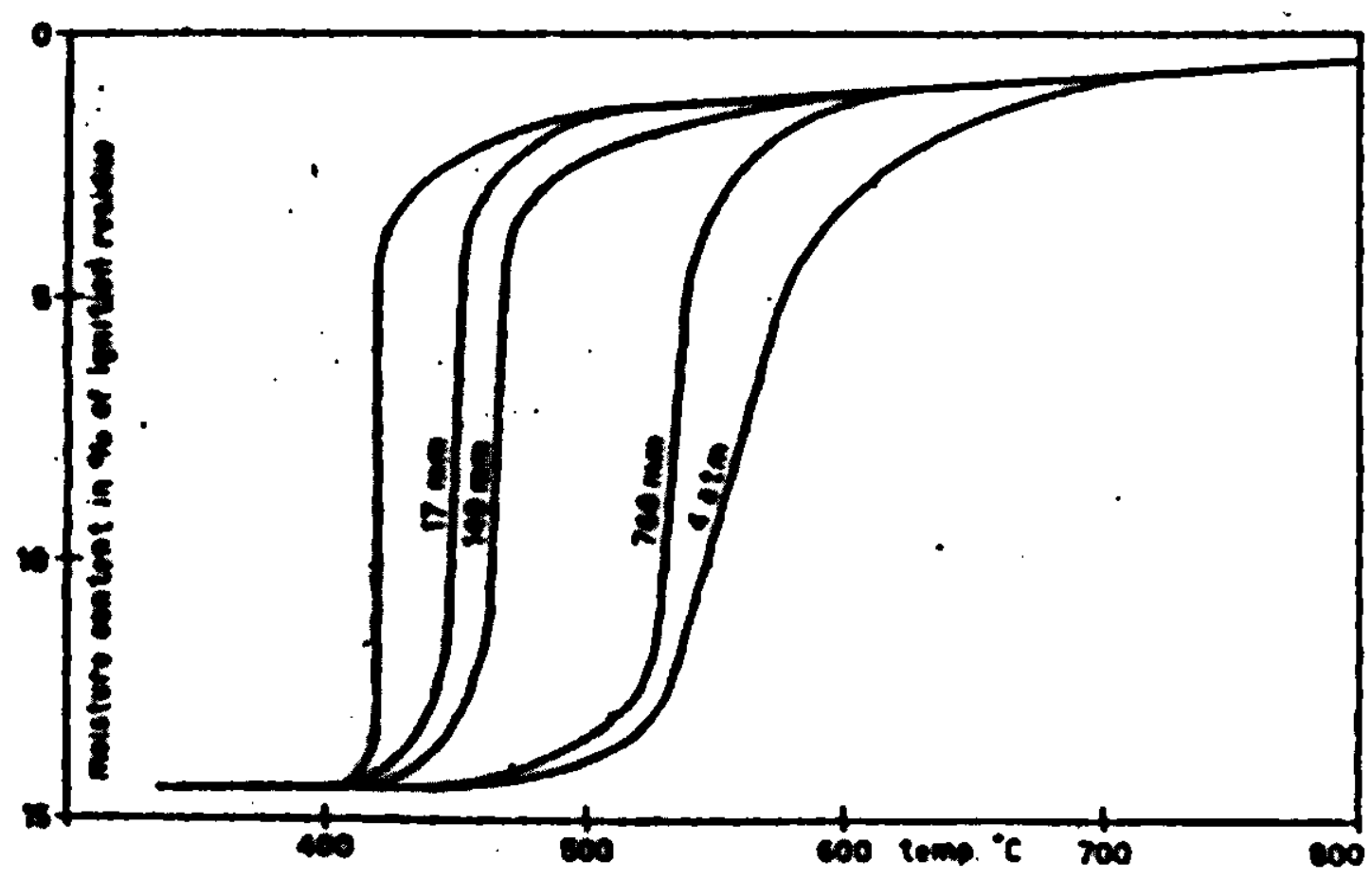

fig. 13. Dehydration of Zettlitz kaolinite as a function of the partial vapour pressure of water in the furnace atmosphere (from PIETERS, 237).

In air of average composition in Holland, the partial vapour pressure of water is about $11 \mathrm{~mm}$ mercury pressure (70\% relative humidity) at room temperature $\left(18^{\circ} \mathrm{C}\right)$. This vapour presoure may in itself account for a delay of the dehydration reaction of kaolinite amounting to 30 - 40 degrees. Approximately the same holda for the dehydration reactions of other minerals. In so far as known the factor of relative humidity has never been considered, in explaining shifts. in reaction temperatures in DTA.

The atmosphere in the furnaces used in this study were not controlled as to composition of the air, though this is considered desirable for accurate analyoes.

As regards carbonates, considerable attention has been given to the decomposition reactions in dependence of the composition of the environmental atmosphere (HEINZ, 151; HUTTIG, 150 and ZATADSKI, 286 a.o.). Here too a close relationship is found between the decomposition temperature and the partial vapour pressure of $\mathrm{CO}_{2}$ in the reaction atmosphere. The reaction may be delajed considerably in environments of relative high $\mathrm{CO}_{2}$ presøure.

Analogous considerations hold for oxydation reactions. If the furnace atmosphere is deficient in oxygen, these reactions may be inhibited.

For certain purposes (as for the inhibition of the oxydation. of organic matter) it is practicable to control the furnace atmosphere composition (ROWLAND and JONES). For such experiments a nitrogen atmosphere may be applied. In so far as known, DTA records in vacuum have never been carried out. Some static (de- 
hydration) experiments carried out in vacuum indicate the lowering of reaction temperatures accompanied by great reaction velocities.

The following conclusions may be drawn.

1. The composition of the furnace atmosphere affects considerably the initiation and course of reactions accompanied by changes in weight.

2. The initiation and course of dehydration reactions are influenced by the partial vapour pressure of water. The decomposition reactions of carbonates are influenced by the partial vapour pressure of $\mathrm{CO}_{2}$ and the oxydation reactions are influenced by the partial vapour pressure of $\mathrm{O}_{2}$ in the furnace atmosphere.

Part II: The clay-bound factors.

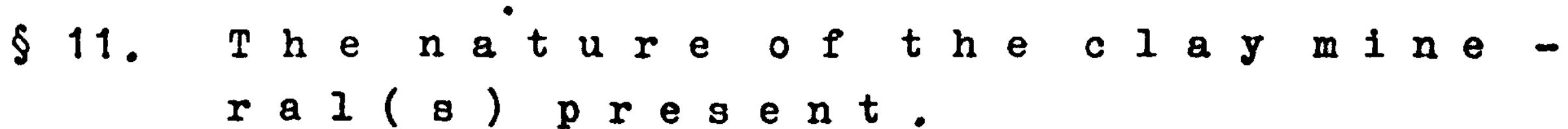

As has been shown above, many apparatus-bound factors mas affect the result of thermal analysis; but these influenoes bring about in most cases only modifications of the primary pattern, which is determined by the nature of the clay. If this were not so, DTA should be unsuitable for clay mineral analyøi.

The dehydration temperatures and the heats of reaction aro specific for the different clay minerals. The thermal stability of crystals depends primarily on binding energies within the crystal lattices. As temperature increases the trend towards increasing the entropy and decreasing the energy of the crystal lattice is manifested.

The result is the decomposition of the cryatal at a distinct temperature.

What interests us primarily here, 1s the mutual influence of clay minerals upon the appearance of thermal reactions. As was observed in the DTA records of artificial mixtures of clay minerals (AGAFONOFF, 1; CAILLERE and ORCEI, 227; CAILLERE, 41; GRIM, 99), a rather considerable peak shifting may occur as a consequence of mixing. The reaction temperatures of the components in the mixture are not the same as the reaction temperatures of the pure components of the mixture. The mutual influence of the components in the mixture has been considered as being analogous to the lowering of melting points of pure components by the addition of admixtures (227). However, the reac- 
tion temperatures are not systematically lowered in DTA, but sometimes increase by the presence of admixtures. There exists consequently a fundamental difference between the two phenomena.

Another point which should be considered is the particle size of the clay. KELIEY and coworkers $(163,165)$ were the first to reveal the influence of grinding of clays upon their dehydration. They found that prolonged grinding result in a breakdown of the crystal lattice. PERKINS (233) made a number of similar experiments. The DTA curves in his publications indicate a decreased intensity of reaction with increased time of grinding. Prolonged grinding lead to a very smooth curve which had no pronounced peaks. Analogous effects of the break-down of clay minerals after prolonged grinding were recorded with $X-r a y$ analysis by JACKSON and TRUOG (153) and with DTA by SPEIL (271) and by KUIP and KERR (174) with ground dickite.

Unlike the effects of fine grinding, just mentioned, increasing particle size of the sample results in strong reactions for the reactions accompanied by changes in weight. The rate of such reactions is controlled largely by diffusion, and should therefore obey to a certain extent the laws of diffusion. Thus the rate of water-108s during dehydration should depend upon the oum of the surface-area of the particles, according to the Iaw of FICK $d m=D^{\circ} a \frac{d c}{d x} d t$ where dm represents a small quantity of water, passing during a time-interval dt through a ourface area $a$, over a concentration gradient $\frac{d c}{d x}$. The diffusion constant $D$ is a constant of the material.

As is well known for a given weight of material the sum of the surface area of particles increases with decreasing particle size. If particle. size is greater than about $20 \mu$, the surface area is toosmall for dehydration reactions to occur rapidIy enough to yleld pronounced reaction effects in current DTA. Thus, when the average alze of particles is $20 \mu$ recorded reactions are faint and are spread over a rather wide temperature range.

Fortunately no clay minerals occur in fractions larger

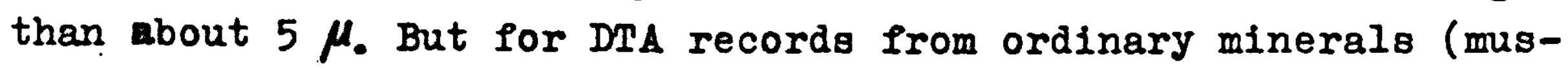
covite, chlorites, vermiculite, feldspars etc.) the limiting value of particle size for pronounced reactions should be considered.

It is obvious that for reactions of the inversion type solid $\mathrm{A}_{1} \rightleftharpoons \operatorname{solid~\mathrm {A}_{2}}$

the considerations of particle size do not hold. For example quartz of diameter $200 \mu$ still shows perfectly the $\alpha \rightarrow \beta$ inversion. 
\$12. Ihe effect of degree of cryatal1 i $z$ a $t$ i o n.

Not all clays consist of perfectly crystallized clay minerals. SEDLETSKII $(261,263)$ was one of the first to call attention to the presence of mutabilites and metastabilites in soil clays. These forms are the products of transition between precipitates in the soll solution and clay minerals.

Preclpitates in the soll solution may be imperfectly crystallized as a consequence of the conditions of the environment (principally low temperature and low atmospheric pressure). Through aging and the intermittent wetting and drying the imperfectly crystallized clay minerals may gradually convert to better crystallized bodies: The process might require ages and ages, depending on constancy of environmental conditions. According to these viewpoints, clay formation would otart with the badly crystallized bodies in the average soil, as was pointed out by EDELMAN and SCHUFFELEN (75).

A well-known example of a clay-mineral of the poorly crystallized type is the fire-clay mineral, closely related to kaolinite, and degcribed independently by FAVEJEE (84) and GRIM (105). According to BRINDLEY and coworkers $(34,36,37)$ the fire-clay mineral should be a transition type between hydrated halloysite and kaolinite. In so far as thermal curves may serve as additional evidence, there is an indication that Brindley's view-point is correct; see fig. 22 .

Expe r i m e n t $s$.

To cover the influence of the degree of crystallization, a number of runs were made from well and poorly cryatallized clay minerals, whether occurring in nature (kaolinites otc.) or artificially prepared (iron and aluminiumahydroxydes).

In fig. 14 and 22 the differential thermal curves of some good crystallized kaolinites (zettlitz, Banka) are compared with the curves of hydrated haliojsites (Mindesberg, Bedford) of fire-clay-minerals (Plemet, Holzhausen) and of a kaolinitehalloysite mixture (Djebel Debar). The intermediate position of the fire-clay minerals is obvious, as regards the general shape of the curves (fig. 22). However, the poorly cryatallized types are characterized by a ohifting of reactions to lower temperature ranges. The reaction intensity is rather low at the same time.

This reaction shifting, in dependence on degree of cryotal- 


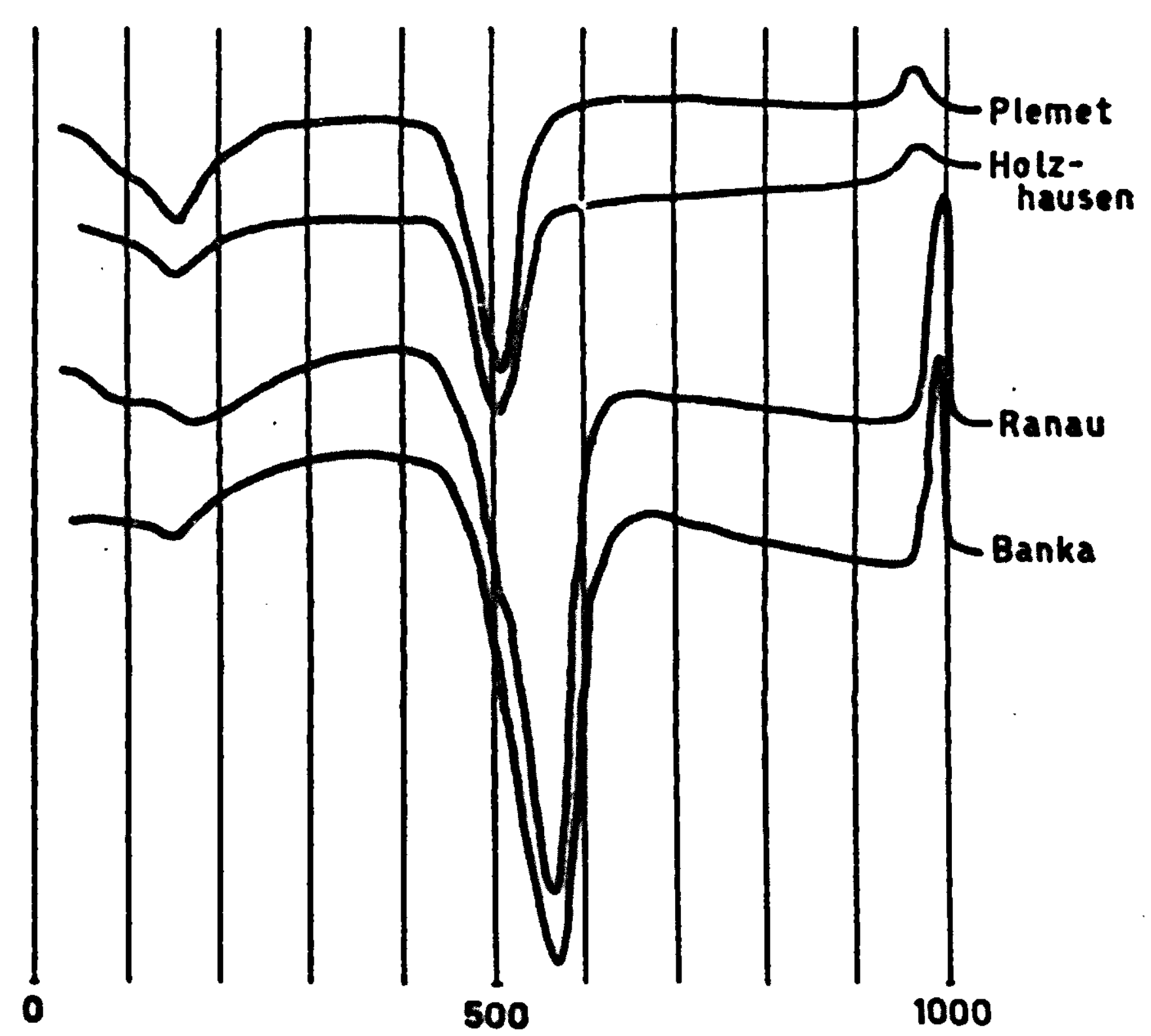

DTA curver of some weli and badly crystallized kaolinites.

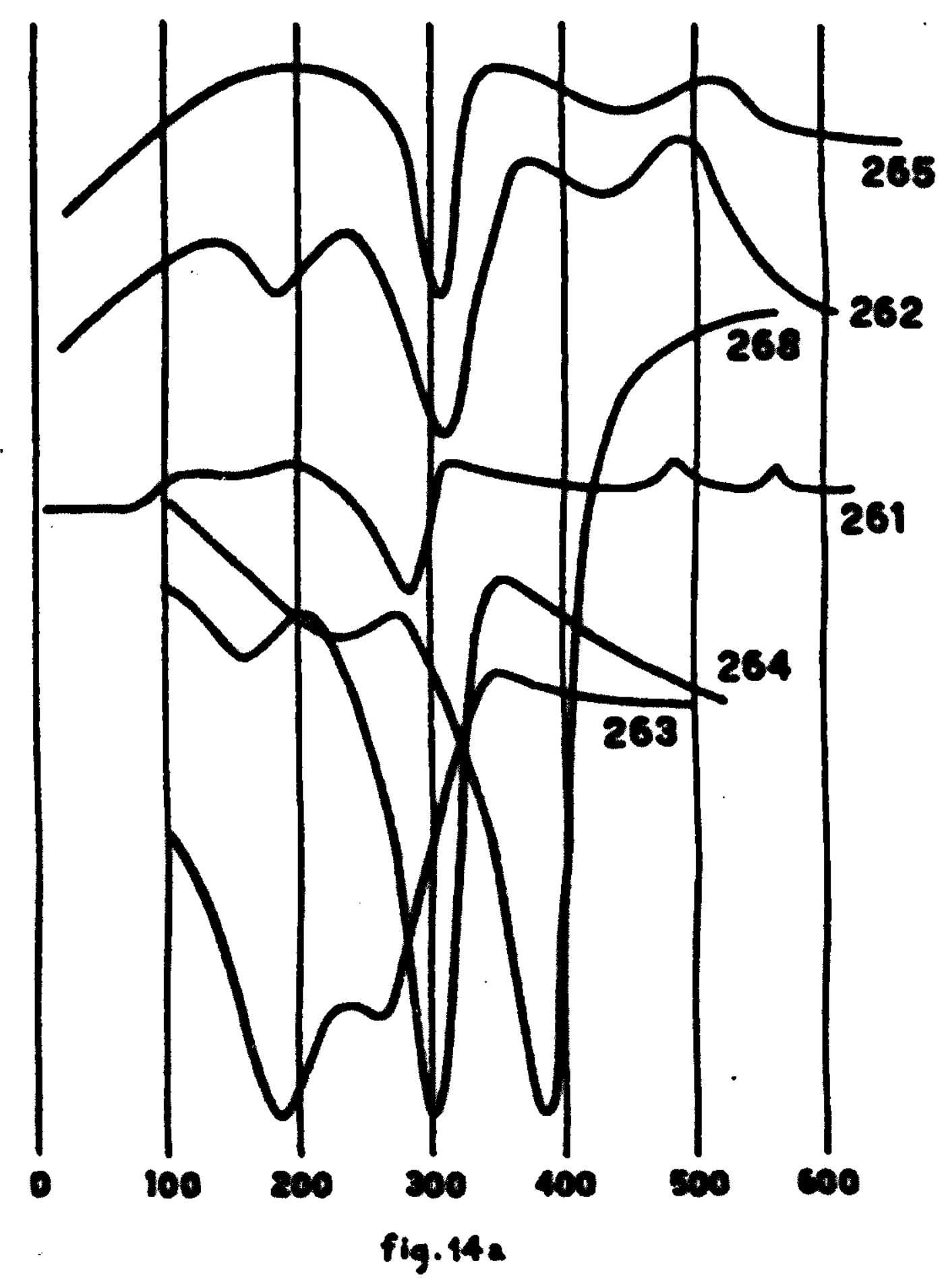


Iization, has been observed by SCHUYLENBORGH and ARENS (259) with a number of hydrous iron-oxydes. The better the crystallization 1s, the higher is the reaction temperature. Fig. $14^{\mathrm{a}}$ shows a number of curves from natural and artificial prepared hydrous iron oxydes. The curves No. 265 and 268 are from well crystallized bodies, the other curves from poorly crystallized ones. In the latter cases the reaction temperatures are lowered and the peaks are of small intensity. The description of the preparation of a range of hydrous oxydes with different degree of crystalization is given in several papers of SCHUYLENBORGH (256-259). The concentration of the starting solutions, the time and the temperature of the precipitation appear to be decisive for the degree of crystallization, as is well-known from the analitical chemistry.

Analogous observations of peak shifting in dependence on crystallization were made by CAILLERE and HENIN $(47,48)$, in experiments with natural and aynthetic antigorite. The badly crystalized synthetic product showed the same general shape of curve as the natural, well cryatallized, body, but peak temperatures of the former were shifted about 200 degrees centigrade downward.

\section{C $\circ$ n 1 u 1 \& 1 n.}

summarizing the effect of degree of cryatallization, it may be stated that the appearance of reactions is exceedingly affected by the degree of crystallization. The better the crystals are grown out, the higher will be the decomposition temperature. Both endothermic and exothermic reactions are affected.

\section{The effectof the adsorbed cat 1 - o $\mathrm{n} \mathbf{8}$.}

One of the properties of clay, discovered hundred years ago by THOMPSON and WAY (66), is its capability to adsorb cations.

The different clay minerals, however, vary among themselves in exchange capacity. In table 6 the exchange capacity of some clays, used in this study, is given. The determinations were made with the percolation-technique of HUDIG and ROBORGH (240) and described by VAN DER MAREL (200). 
Table 6.

Exchange capacity of various clay minerals.

\begin{tabular}{|lc|}
\hline Name and location & $\begin{array}{c}\text { Exchange cap. pH=6.5 } \\
\text { m.e. per 100 gr. }\end{array}$ \\
\hline & $\cdots$ \\
Kaolinite - Banka (no. 59) & 6.5 \\
Kaolinite - Drybranch & 7.3 \\
Halloysite-4 - Pekalongan (no. 25) & 28.0 \\
Illite - Ingum & 29.0 \\
Montmorillonite - Osage & 83.1 \\
Montmorilionite - Geigenheim (no. 46) & 78.8 \\
Montmorillonite - Fyo. bentonite (no. 3) & 54.1 \\
Vermiculite - S.Africa (V) & 130 \\
\hline
\end{tabular}

As the adsorbed cations are hydrated, it is to be expected that these will affect the DTA curves. HENDRICKS, NELSON and ALEXANDER (139) proved this for a number of montmorillonites seturated with various cations. In the low temperature range $\left(0-300^{\circ} \mathrm{C}\right)$ of the curves of montmorilionites there may be distinguished two peaks (see fig. 1). One peak stems from the hydration water of the clay mineral itself (interlayer water) and one originates from the hydration water of the adsorbed cation(s). The magnitude of this latter peak is subject to the hydration of the adsorbed cation. According to HENDRICKS and coworkers the hydration 18 as follows. $\mathrm{Mg}, \mathrm{Ca}, \mathrm{Sr}$ and $\mathrm{Ba}$ appear to be the most hydrated, they have about 6 watermolecules of hydration water per lon. Next comes il with 3 molecules of hydration water. Flnally there are $\mathrm{H}, \mathrm{K}, \mathrm{Na}$, and $\mathrm{Cs}$ with one or no molecules of hydration water, according to HENDRICKS c.s. These results are critical reviewed by FORSLIND (87).

Similar experiments of the influence of the nature of the adsorbed cations upon DTA results were made by CAILLERE, HENIN and TURC $(43,44)$. They found an Al-saturated complex in certain caser to be advantageous, because a more pronounced curve could be obtained with it. The presence of iron in the exchange complex was found to platten the peaks (see ORCEL, 226 and CAIIIERE and HENIN, 45).

As regards the nature of the adsorbed cations, vermiculites are the most sensitive; both with respect to DTA response and to $X$-ray analysis, as was revealed by $B A R S H A D(15,16,17)$ and WALKER (278, 279). It appeared from Ixray and DTA records thät natural vermiculite, which is probabls $\mathrm{Mg} \mathrm{OH}{ }^{+}$-saturated, could be converted to blotite by K-saturation, as Ca- and Ba-vermicu- 

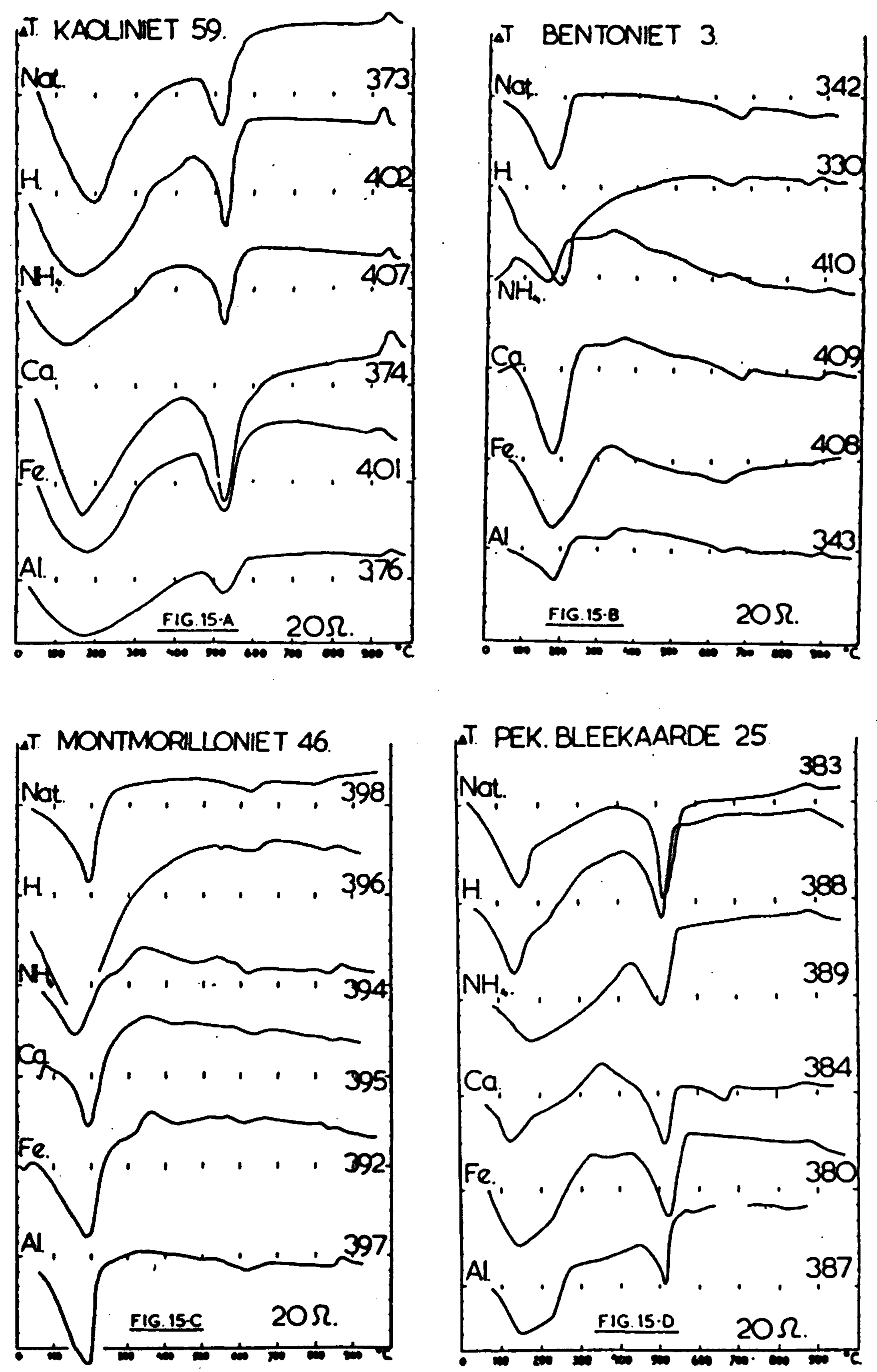

Fig. 15. DTA curves of kaolinite (Banka 59), Montmorillonite (Wyo, bentonite no. 3 and Geisenheim no. 46) and fram a bleacking clay (Pekalongan), saturated with various cations. 
I1tes on the other hand behaved like the original natural body. But $\mathrm{HH}_{4}$-saturated vermiculite reacted totally different. WALKER (279) pointed out that saturation with $\mathrm{Sr}^{++}, \mathrm{Ca}^{++}, \mathrm{Mg}^{++}$and $\mathrm{Be}{ }^{++}$ give rive to the most hydrated vermiculite-complex. Next comes saturation with $\mathrm{Na}^{+}$and $\mathrm{Al}^{+++}$. $\mathrm{II}^{+}$complexes are still less hydrated; $\mathrm{KH}_{4}^{+}$and $\mathrm{K}^{+}$saturation leads to the least hydrated form. Another 1tem, which should be sonsidered in this section, Is the influence of the presence of organic cations, in so far as these oxydize and decompose during heating. DTA records of clays saturated with complezes of organic cations have been made by ALEATAY ( 9 ) and BRADLEY and GRIM (31). In clays with relative high'adsorblire capacities, saturation with organia cations may serve in the additional characterization of the nature of the clay mineral, e.8., in the distinction of beidelite, saponite, bectorite and montmorilionite, and in the distinction of these from micaceous clay minerals.

$E \times p e r 1$ in $e^{\prime}$.

A number of experiments were made with clays, saturated with different cations, to reveal the influence of the adsorbed cations. To saturate the complex with the various cations, clay separates were treated 5 days with excess $0.1 \mathrm{n}$ solutions of the chlorides of $\mathrm{Fe}, \mathrm{Al}, \mathrm{Ca}, \mathrm{Mg}_{\mathrm{g}} \mathrm{NH}_{4}$ and $\mathrm{Na}$ and $0.05 \mathrm{n} \mathrm{HCl}$ respectively. Subsequently the clays were brought into cellophane bags and dialyzed until no more free chloride could be detected in the outer solution. The clays were then dried, first on a steam bath, and, subsequently, in a thermostat at $105^{\circ} \mathrm{C}$.

The results of the DTA runs are recorded in $f i g .15^{a-d}$ and $16^{a-b}$. It appears that the clays with the smallest exchange capacity (kaolinites) are the least affected by the variations in adsorbed cations, except in the case of Fe and Al. The hydrogen saturated clajs give rise in most cases to the most pronounced curves. From the $\mathrm{NH}_{4}$-aaturated clays it was difficult to obtain reproducible results. With these clays, heating causes the transition

$$
\mathrm{NH}_{4} \text {-clay } \rightarrow \mathrm{H}-\mathrm{clay}+\mathrm{NH}_{3}
$$

which is a reaction in addition to dehydration. Probably this additional reaction may account for the exceptional thermal behaviour of $\mathrm{NH}_{4}$-clays. In the higher temperature range 8 the $\mathrm{NH}_{4}$ clays behave as $\mathrm{H}-\mathrm{cl} 8 \mathrm{~g}$, a regards thermal reactions.

The curves of montmorillonites and vermiculites are affected most by the cations adsorbed. Since saturation with $\mathrm{Ca}$ ana Mg gives rise to a double-peaked endothermal reaction below 

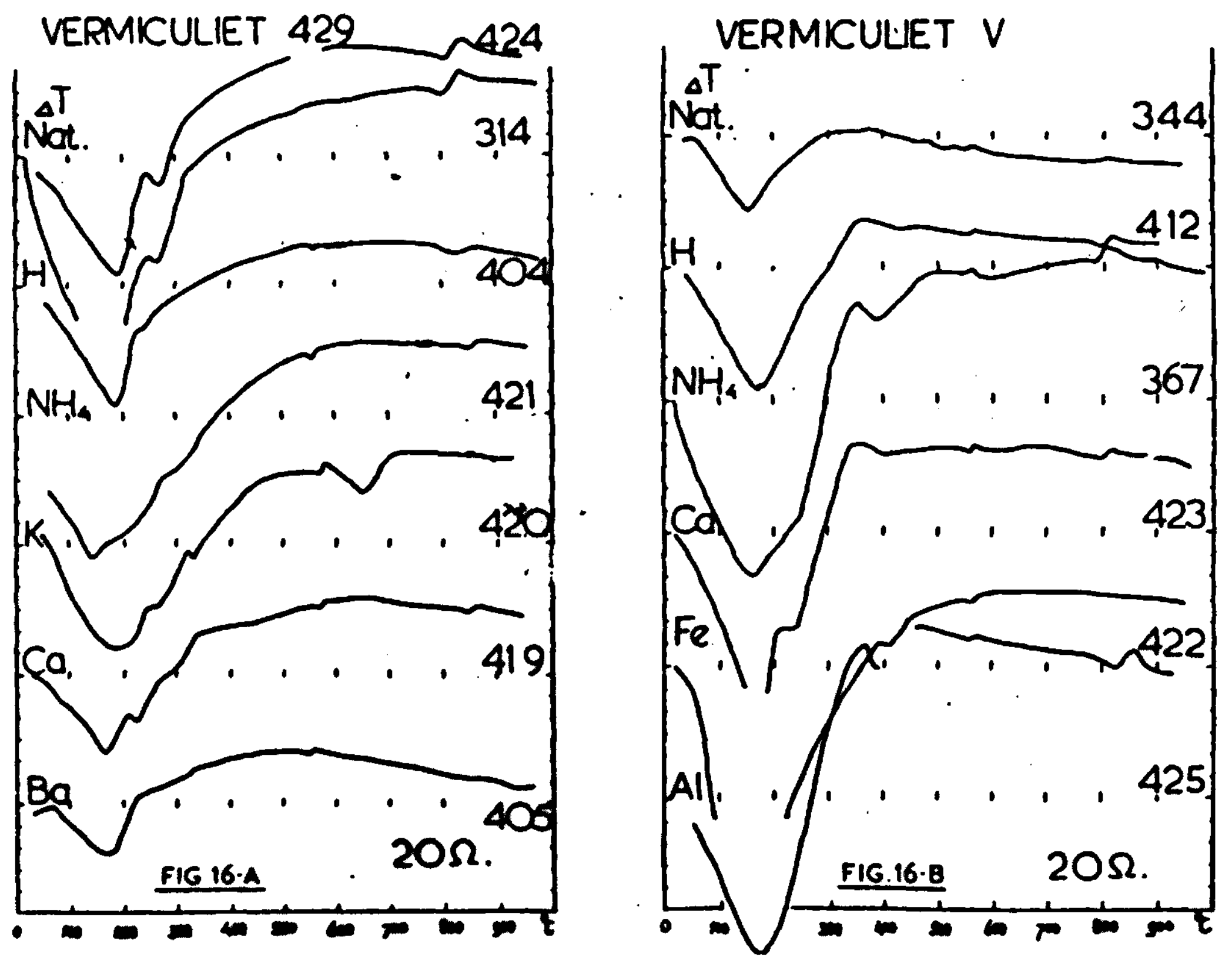

fig. 16. DTA curves of vermiculites, saturated with different cations.

$300^{\circ} \mathrm{C}$, this sharacter might serve to distinguish between Naand $\mathrm{K}$-montmorillonites, and $\mathrm{Ca}$ - and $\mathrm{Mg}$-montmorillonites. The former show only a single-peaked reaction below $300^{\circ} \mathrm{C}$.

C $\circ$ n c l u s i o n s.

From the present observations and from observations quoted from literature, the following conclusions are justified.

1. The effest of the nature of the adsorbed cation is of increasing importance with increasing exchange capacity. The effect is smallest for kaolinites and the most pronounced for vermiculites (fig. 15 and $16^{\mathrm{a}-\mathrm{b}}$ ).

2. Saturation of the clay with hydrogen (by means of repeated treatment with hydrochloric acid in a concentration not exceeding $0.05 \mathrm{n}$ ) yields the most pronounced DTA curves for all minerals investigated.

3. Saturation with $\mathrm{Fe}^{+++}$or $\mathrm{Al}^{+++}$in most cases elattens the curves, even with kaolinites.

4. Ammonium saturation gives rise to an additiónal reaction

$$
\mathrm{NH}_{4} \text {-clay } \rightarrow \mathrm{H}-\mathrm{clay}+\mathrm{NH}_{3} \text {. }
$$

5. In montmorilionites $\mathrm{Ca}^{++}$and $\mathrm{Mg}^{++}$saturation leads to dou-. ble -peaked endothermal reaction in the low temperature range.

6. Treatment of clays with organic cations may facilitate the distinction of clay minerals, especially in the case of the montmorillonites. 
§ 14. The effect of the presence of a dm $i x t u r$ es.

The presence of salts may seriougly interfere with the normal courge of DTA curves.

CAILLERE and HENIN (46) showed how DTPA curves were modifled for various clay minerals, treated with $\mathrm{Al}\left(\mathrm{NO}_{3}\right)_{3}, \mathrm{AlCl}_{3}$, $\left(\mathrm{NH}_{4}\right)_{2} \mathrm{CO}_{3}$ and $\mathrm{K}_{2} \mathrm{SiO}_{3}$. The treatment with $\mathrm{Al}\left(\mathrm{NO}_{3}\right)_{3}$ generally resulted in a more pronounced DTA curve for montmorillonites (exoept nontronite) and for illite-bravaisite. On the other hand this same treatment flattened the curves of anauxite and attapulgite-paljgorskite. Kaolinites treated with $\mathrm{AlCl}_{3}$ showed a pronounced exothermic reaction at $950^{\circ} \mathrm{C}$. The curve of nontronite could be improved by treating the clay with $\left(\mathrm{NH}_{4}\right)_{2} \mathrm{CO}_{3}$. Treatment of montmorillonite with potassium silicate resulted in curves which were more pronounced.

GROVER and coworkers (117) observed the reactions of kaolinites after mixing with sodium chloride and sodium carbonate. A $2 \%$ and at1ll more a 5\% admixture of carbonate resulted in considerable reduced reaction rates, as was evidenced by flattening of the curves. NaCl only affected the curves if present in quantities as high as $5 \%$ or more. For the decomposition reactions of carbonates similar observations were made by ESIN, GEL'D and POPEL (77). These reactions likewise are subject to considerable modification, due to the presence of salts.

Organlc admixtures may considerably interfere in DTA records. AGAFONOFF and JOURACSKY (2) observed that normal soil organic matter was decomposed between room temperature and $600^{\circ} \mathrm{C}$ in thermal analysis experiments. The decomposition reaction is essentially exothermic, but spread over a rather wide temperature range. The same observations were made by CAILLERE and HENIN (46). BRADLEY and GRIM (31) found the decomposition of various amines, with which the clay was treated, to take place in distinct temperature ranges, but always below $600^{\circ} \mathrm{C}$. In particular the curves of montmorillonites could be considerably modified. The work of ALLAWAY (9) has been quoted previously.

Exper 1 m e nto.

In some experiments glycerol treated clays (prepared according to the technique devellopped by MACEWAN (190) for $X$-ray analysis) were submitted to DTA. With kaolinite and illite no additional reaction was found, as was expected; while montmorillonites shored an additional exothermic peak (fig. 17). In 
another set of experiments some methylated clays, prepared according to the technique of BERGER (23), were submitted to DTA. The decomposition of the bound methoxyl groups resulted in an additional exothermic reaction in montmorillonites. The glycerol-solvation of clay minerals, previous to differential thermal analysis, is another means for distinguishing the montmorillonite clays from the illites, the former being subject to the reaction, the latter not.

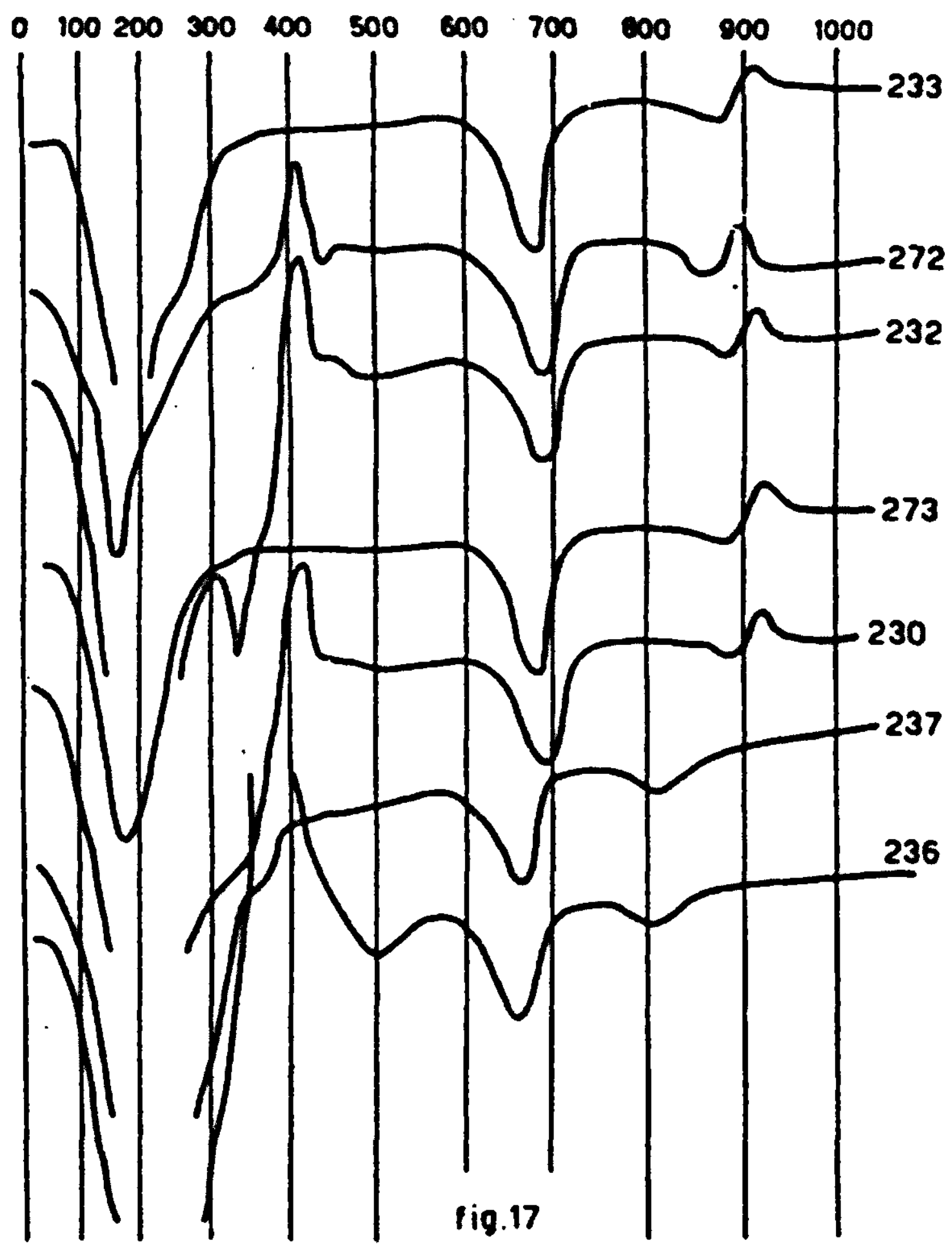

DTA curves of montmorillonites, glycerol treated and methylated. Run no. 233: montm. from Wyo, bentonite. 272. the same, methyl ated, 232. the same glycerol treated. 273 Geisenheim, natural, 230. the same, glycerol treated. 237. Thixoton, 236, the same, glycerol treated.

C $\circ$ n $~ I u$ a 1 ○ $n$ s.

Summarizing this paragraph, the following may be said:

1. Salt admixtures in the clay may seriously interfere with the appearance of reactions in DTA, but not if present in quantities smaller than about $2 \%$.

2. By means of various treatments with organic materialo (glycerol-solvation, methylation), the identification of the clay-minerals of the montmorillonite group may be $f a-$ cilitated. 


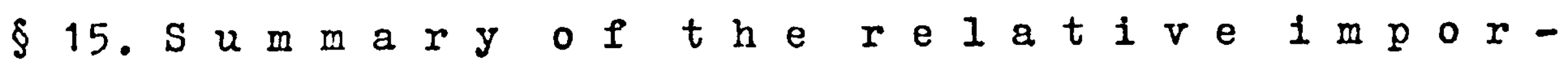
t a n e o $f$ the $f$ a c t o r s.

Fina 1 r e m a $r k$.

With the data at hand, and those of others, briefly reviewed in this chapter, it is clear that there are various ways in which DTA curves may be modifier. Some of the modifications may improve the records of certain reactions, while at the same time other reactions may be seriously inhibited. In order to avoid mistakes and to get maximum information about a clay under invertigation, the operation under different experimental conditions with the same sample, is fully recommendable.

The conclusions from the various paragraphs in this chapter is given in tabulated form in table 7. The relative importance of the factors involved is indicated by plus and minus signs.

Table 7 .

Summary of the relative influence of various experimental factors upon the DTA records of clays.

\begin{tabular}{|l|c|c|c|c|}
\hline Factor & $\begin{array}{c}\text { modifies: } \\
\text { peak } \\
\text { shifting }\end{array}$ & $\begin{array}{c}\text { peak } \\
\text { height }\end{array}$ & $\begin{array}{c}\text { peak } \\
\text { range }\end{array}$ & $\begin{array}{c}\text { peak } \\
\text { surface }\end{array}$ \\
\hline heating rate & ++ & ++ & ++ & ++ \\
Ni sample block & - & + & + & + \\
leram. sample block & - & + & + & + \\
increasing radius of holes & ++ & ++ & ++ & + \\
increasing depth of holes & ++ & ++ & ++ & + \\
thermocouples & -- & - & - & - \\
nature of inert substance & ++ & - & - & - \\
tight packing & - & + & - & + \\
covering the holes & ++ & ++ & ++ & ++ \\
increaging vapour pressure & ++ & ++ & ++ & ++ \\
\hline
\end{tabular}

The practicability of DTA thus greatly depends upon experimental conditions. When otarting with DTA the thing is to find out the best operating conditions, in order to get the most valuable records. In this study it was found impossible to give a single formula for these best operating conditions, though certain recommendations can be made.

Steep heating rates and tight packing were found to be desirable. The heating rate of $10-12$ degrees $c$ per minute, u- 
sually recommended in the literature $(174,271)$, was found insufficient in most cases. The heating rate should be 20 degrees $C$ per minute or higher, as steep heating rates enhance all types of reaction. Tight packing also tends to accentuate all types of reaction.

As regards the other experimental factors, no generalizat1ons could be made. A nickel sample block has no general advantages over a ceramic block, as in the former the exothermic reactions tend to be accentuated and in the latter the endothermic reactions are enhanced. Deep and narrow sample holes in the holder have no general advantages over wide and shallow holes; the reactions accompanied by weight $108 s$ are accentuated in the former type of holes, while oxydation reactions and exothermic inversion reactions are accentuated in the latter type.

Likewise, variation of the inert substance and the use of calcined clay as such, has advantages in certain respects and disadvantages in other respects, depending on the nature of clay to be investigated.

However, this variability of experimental conditions is one of the main advantages of DTA over other methods of clay minerals identification: By a choice of optimum operating conditions it enables one for any particular case to get the maximum information available. In other words: the operating conditions should be adapted to the problem to be studied.

If one is to study qualitatively the nature of clay the following guide lines can be set down:

1. kaolinite materials, including halloysites, can be identified succesfully under the following operating conditions: a the heating rate should be moderate to steep(10 degrees $($ per minute or higher);

b a nickel block or other blook with great heat conductivity coefficient should be used;

$\subseteq$ the ratio of depth to radius of the sample holes should be 1 or greater than 1;

d the packing should be tight;

e covering of the sample holes during the run may be advantageous;

1 there 1s no preference as to the inert substanceto be used.

2. If illite materials are expected to be present, the following recommendations can be made as to operating conditione \& 
a a steep heating rate (20 degrees $C$ per minute or higher);

b the use of a ceramic block or other block with Iow heat conductivity coefficient;

c a narrow, and deep sample holes;

d packing in the holes should be tight;

e calcined clay should not be used as inert material, but preferably calcined $\mathrm{Al}_{2} \mathrm{O}_{3}$, 'to detect admixtures of quartz;

1 covering of the holes is not recommendable, as then the oxydation of ferrous iron, which may be present in the lattice, is masked (as in glauconite for instance).

3. If montmorillonitic clay-minerals (and. vermiculites) are expected to be present, the same operating conditions as were indicated for illitic materials can be recommended, except $2^{c}$. Often the use of sample holes with a ratio of depth to radius of 1 or more is advantageous for montmorillonites, in order to detect the high temperature inversion reactions.

4. For the detection of hydrous oxydes of iron and alumina (if present in small quantities) the following operating conditions may be recommended:

a - a steep heating rate (20 degrees $C$ per minute or higher);

b two subsequent runnings should be made, one in a block with great heat conductivity coefficient and one in a block with small heat conductivity coefficient, to be sure that no endothermic reaction is overlooked;

c the ratio of depth to radius of the sample holes should be 1 or greater than 1;

d packing should be tight;

e there is no preference as to the inert substance to be used;

$\underline{f}$ covering of the sample holes is advantageous.

5. Carbonates can be detected. With ease under various conditions, but the following recommendations maj aid:

a a moderate to steep heating rate should be preferred;

b the use of a ceramic sample block is adviseable; 
c the ratio of depth to radius of the sample holes should exceed 1 for calcite, dolomite, aragonite, smithsonite and other non-oxydiseable carbonates; the ratio should be about 1 for siderite, rhodochrosite and other carbonates subject to oxjdation;

d generally the sample holes should not be covered during the running. 


\section{THEORETICAL CONSIDERATIONS OF THE}

\section{DIFFERENTIAL THERMAL ANALYSIS -}

As has been seen in the preceding chapters, DTA of clay consiste of the recording of thermal reactions, produced during heating. The recording is made by means of a differential thermocouple with one. junction inserted in the clay sample. The reference function is inserted in any thermally inert substance. Both oubstances are heated simultaneously in the same furnace.

For an adequate understanding of the records and for an explanation of the peculiarities, indicated in chapter 3 , it is neccessary first to consider the heat mechanics in the samples and in the sample holder. This includes an understanding of the effect of heating rate, depth and radius of the sample holes, thermal properties of clay and inert substance, etc..

Furthermore, the kinetics of the reactions in the thermalIy active substance should be considered, because the reaction rate (expressed as heat of reaction as a function of time) determines the shope of the DTA curves.

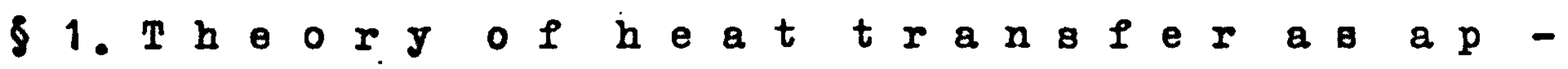
p 1 ie d t o DTA.

The clay and the inert sample in one and the same experiment differ among themselves in

a. specific heat;

b. heat conductivity.

Let us first consider the influence of heating upon the $m e$ a $n$ temperature of the clay sample and the inert sample, leaving out of consideration, for the time being, the difference in heat conductivity.

If the specific heat of the inert material and of the cla resp. amounts $c_{1}$ and $c_{2}$, it follows for the simultaneous heating of both oubstances:

$$
\begin{aligned}
& \text { for the inert rample } c_{1}=\frac{Q}{m_{1}\left(I_{2}-L_{1}\right)} \\
& \text { for the clas sample } c_{2}=\frac{Q}{m_{2}\left(I_{2}-L_{1}\right)}
\end{aligned}
$$

where $Q=$ number of oalories oupplied; $Q$ is equal for both gam- 
ples in one and the same furnace;

$m_{1}=$ weight of the inert sample;

$\mathbf{m}_{2}=$ weight of the clay sample;

$\mathrm{r}_{1}=$ initial $\mathrm{m}$ e a $\mathrm{n}$ temperature of the samples;

$\mathrm{T}_{2}$ resp. $\mathrm{T}^{\prime}{ }_{2}=$ final $\mathrm{m}$ e a $\mathrm{n}$ temperature of the samples. Combination of (1) and (2) gives:

$c_{1} m_{1}\left(T_{2}-T_{1}\right)=c_{2} m_{2}\left(T_{2}-T_{1}\right)$

In order to get straight zero lines over temperature ranges, where no reactions occur the following condition must be as tisfied

$$
T_{2}-T_{1}=T_{2}-T_{1}
$$

This condition is only obeyed when

$$
c_{1} m_{1}=c_{2} m_{2}
$$

In words: the weights of the samples should be inversely proportional to their specific heats (cf. JEFFRIES, 158).

As appears from the literature the condition expressed in equation 3 ordinarily is not satisfied in DTA experiments. This is one of the causes of deviation of the differential temperature line in temperature ranges where no reactions occur.

In the above mention was made of the m e a $n$ temperature of both clay and inert sample. Actually; no m e a $n$ temperatures are measured, but real temperatures at time $t$ and distance $\underline{r}$ from the wall of the cylindrical sample hole. Consequently, the heat conductivity and the dimensions of the sample holes should be considered.

In the following discusssions the thermocouples are assumed to be negligibly small with respect to the mase of clay and inert material present.

The heat conductivity $\lambda$ of any substance is defined by

$$
d Q=\lambda F \frac{d T}{d x} \cdot d t
$$

where $Q=$ the number of calories passing in the time $t$ through a face of area $F$.

$\frac{d T}{d x}=$ temperature gradient, perpendicular to the face.

For mono-dimensional heat flow it follows from equation 4 for the non-stationary heating proses (see $157,175,191^{a}$ )

$$
\frac{d T}{d t}=a\left(\frac{d^{2} T}{d x^{2}}\right)
$$


Equation 5 describes the temperature-course in any substance as a function of time $t$, distance $\underline{x}$ from the source of heat and the thermal diffusivity a. The themal diffusivity a is given by

$$
a=\frac{\lambda}{c \rho}
$$

where $c$ is the specific heat and $p$ the specific. weight of the material.

For the derivation of equation (5) the reader is referred to the text-books on heat trangfer, as for ingtance, MACADAMS 175, JAKOB 157, KRONIG 19\%0, etc.

The general equation for three dimengional heat transer in a non-stationary process is

$$
\frac{d T}{d t}=a\left(\frac{d^{2} T}{d x^{2}}+\frac{d^{2} T}{d y^{2}}+\frac{d^{2} T}{d z^{2}}\right)
$$

where $I, y$ and $\underline{z}$ represent the three cobrdinates.

For the heating and cooling of cylindrical bodies NEWMAN (see 157) derived the equation

$$
\frac{d T}{d t}=a\left(\frac{d^{2} T}{d r^{2}}+\frac{1}{r} \frac{d T}{d r}+\frac{d^{2} T}{d h^{2}}\right)
$$

where $r$ = radial corrdinate;

$h=$ longitudinal axis corrdinate.

The line $r=R$ represents the axis of the cylinder.

In cases where $r$ is amall compared with $h$, the heat transport in axial direction may be neglected to the heat trangport in radial direction, equation (7) becoming

$$
\frac{d T}{d t}=a\left(\frac{d^{2} T}{d r^{2}}+\frac{1}{r} \frac{d T}{d r}\right) .
$$

By cholce of sample holdere with $h>r_{1}$. equation (8) may be ueed to describe the temperature courge in a cylinder a a function of time and distance. A solution of equation (8) is given in appendix $I$. As is seen there, the partioular oolution for DTA experimento 18:

$$
T_{t, r}=T_{0}=\frac{1}{4 a} \frac{d T}{d t} \cdot r^{2}+\frac{d T}{d t} t
$$

where $T_{t, r}=$ absolute temperature at time $t$ and distance $r$ from the wall of the cJlindrical hole, in the inert material;

$T_{0}=$ initial absolute temperature of the experiment; 


$$
\begin{aligned}
\frac{d T}{d t}= & \text { temperature rise of the furnace, as measured in the } \\
& \text { inert substance; } \\
r= & \text { radius of the sample hole; } \\
t= & \text { time; } \\
a= & \text { thermal diffusivity of inert substance. }
\end{aligned}
$$

In temperature ranges where no reactions occur in the clay sample, equation 9 may be applied to both clay sample and inert sample. As applied to the clay sample the formulation becomes:

$$
T^{\prime} t, r-T_{0}=\frac{1}{4 a} \frac{d T}{d t} r^{2}+\frac{d T}{d t} t
$$

Subtraction of (9) from (10) leads to

$$
T^{\prime} t, r-T_{t, r}=\Delta T=\frac{1}{4} \frac{d T}{d t} r^{2}\left(\frac{1}{a},-\frac{1}{a}\right)
$$

This equation represents the relation of $\Delta T$ with heating rate, radius of the sample holes and the thermal diffusivities of clay and inert material in DTA experiments. Its bearing upon peak shifting and its quantitative importance will be illustrated in chapter $V$. It suffices here, to indicate that equation 11 is applicable also in temperature ranges in which reactions occur in the clay sample.

In table 8 values of the coefficients a are given for a number of clays and minerals. The values of a are calculated with the aid of equation (6), from the specific weight the specific heat and the heat conductivity coefficient of the several materials.

If the radius of the sample holes and the heating rate in any experiment is known the value of equation 11 may be calculated. As will be shown in $\mathrm{Ch} . \mathrm{V}$ the calculated values agree fairIy well with the observed values.

In the application of the values of a in table 8 to DTA, a complication arises. In powdered substances air is present between the particles, causing a decrease in heat conductivity coefficient of the powder as compared with the solid substance.

SMITH $\left(269^{2}\right)$ gave a discussion of the influence of porosity upon the heat conductivity of powdered substances and arrived at the equation:

$$
\lambda=\lambda_{8} P_{s}+\lambda_{a} P_{a}
$$

where $\lambda$ represents the over-all heat conductivity of the (otructureless) powder, $\lambda_{g}$ the heat conductivity of the solid component, $\lambda_{a}$ the heat conductivity of the air, $P_{8}$ and $P_{a}$ reop. the 
fraction of solid subatance and the fraction of air per unit volume. $P_{a}$ and $P_{a}$ are dimensionless; $P_{a}+P_{a}=1$.

Table 8.

Values of $c, \rho, \lambda$ and $\underline{a}$ for different materials, used in DTA experiments.

\begin{tabular}{|c|c|c|c|c|}
\hline substance & $\int \begin{array}{c}\rho \\
\mathrm{gr} \mathrm{cm}^{-3}\end{array}$ & $\frac{c}{c a l ~} \mathrm{gr}^{-1} \mathrm{O}_{\mathrm{C}^{-1}}$ & $\begin{array}{l}\lambda \cdot 10^{3} \\
\operatorname{cal} \mathrm{cm}^{-1}{ }^{\circ} \mathrm{c}^{-1} \sec ^{-1}\end{array}$ & $\begin{array}{r}\left.\frac{1}{a} \cdot *\right) \\
\sec \mathrm{cm}^{-2}\end{array}$ \\
\hline $\mathrm{Al}_{2} \mathrm{O}_{3}\left(\mathrm{calc} c_{.}\right)$ & 3.8 & 0.185 & 1.62 & 433 \\
\hline kaolinite & 2.68 & 0.233 & 0.72 & 867 \\
\hline montmorillonite & 2.61 & 0.184 & 0.69 & 696 \\
\hline illite & 2.69 & 0.226 & 0.75 & 811 \\
\hline muscovite & 2.78 & 0.206 & 0.86 & 666 \\
\hline halloysite-2 & 2.67 & 0.208 & 0.84 & 661 \\
\hline quartz, coarse & 2.65 & 0.238 & 0.93 & 678 \\
\hline quartz,fine & 2.65 & 0.238 & 0.50 & 1262 \\
\hline chalcedon & 2.60 & 0.193 & 0.86 & 584 \\
\hline calcite & 2.71 & 0.208 & 0.50 & 1128 \\
\hline dolomite & 2.85. & 0.222 & 0.61 & 1038 \\
\hline haematite & 5.1 & 0.182 & 1.41 & 658 \\
\hline goethite & 4.2 & 0.249 & 1.06 & 987 \\
\hline lepidocrocite & 4.1 & - & - & - \\
\hline limonite & 3.8 & - & - & - \\
\hline diaspore & 3.7 & 0.180 & 1.49 & 447 \\
\hline gibbsite & 2.4 & 0.242 & - & - \\
\hline
\end{tabular}

*) values at room temperature.

Data compiled from: BAVER (20), BLANCK (Hb), HODGMAN (142), JEFPRIES (158), IANDOLT-BORNSTEIN (Tab.), IAANGE (180), PERRY(Hb). SINGER (269), SMITH (2699); SOSMAN (273) and de WIT and ARENS (283).

For tight packed powders $P_{a}$ approximates $0.3, P_{g} 0.7$. The heat conductivity of the air $\mathrm{l}_{\mathrm{ig}}^{\mathrm{a}} 5,7 \cdot 10^{-5} \mathrm{cal} \mathrm{cm}^{-1} \mathrm{sec}^{-1} \mathrm{o}^{-1}$ at room temperature. For granitic material $\lambda_{s}$ is about $7.10^{-3}$ cal $\mathrm{cm}^{-1}$ sec $^{-1}{ }^{\circ} \mathrm{C}^{-1}$ at room temperature. The over-all heat conductirity of the granitic powder should equal:

$$
\lambda=0,3 \cdot 5,7 \cdot 10^{-5}+0,7 \cdot 7 \cdot 10^{-3}=4,92 \cdot 10^{-3}
$$

Ls was polnted out by SMITH the values thus calculated a- 
greed well with the observed values.

In table $8 \lambda_{s}$ is given. For the application of equation 11 however the corrected values of $\lambda$ should be used, as calculated from equation 12.

In this study $\mathrm{P}_{\mathrm{a}}$ and $\mathrm{P}_{\mathrm{g}}$ were determined for some tightly packed and very loosely packed clay materials and inert material (calcined $\mathrm{Al}_{2} \mathrm{O}_{3}$ ). The values are given in table $9 . \mathrm{P}_{\mathbf{g}}$ was calcur lated from the weight of solid material (m), its specific weight $(p)$ and thetotal volume of the clay in the sample hole $\left(\pi r^{2} h\right)$, according to the equation

$$
P_{s}=\rho_{m} / \pi r^{2} h
$$

$P_{a}$ was computed from $P_{\mathbf{g}}$, according to $P_{a}=1-P_{\mathbf{B}}$

\section{Table 9.}

Values of $\mathrm{P}_{\mathrm{a}}$ and $\mathrm{P}_{\mathrm{s}}$ for tight packing and very loose packing of some materials used in DTA.

\begin{tabular}{|l|l|l|l|l|l|l|}
\hline substance & packing & $\begin{array}{c}\mathrm{m} \\
\mathrm{gmms}\end{array}$ & $\begin{array}{c}\rho \\
\mathrm{gr.cm}\end{array}$ & $\begin{array}{c}\pi \mathrm{r}^{2} \mathrm{~h} \\
\mathrm{~cm}^{3}\end{array}$ & $\mathrm{P}_{\mathrm{g}}$ & $\mathrm{P}_{\mathrm{a}}$ \\
\hline $\mathrm{Al}_{2} \mathrm{O}_{3}$ & tight & 0.860 & 3.8 & 0.282 & 0.81 & 0.19 \\
do & loose & 0.410 & 3.8 & 0.254 & 0.42 & 0.58 \\
kaolinite Banka & tight & 0.475 & 2.6 & 0.254 & 0.72 & 0.28 \\
do & loose & 0.365 & 2.6 & 0.313 & 0.45 & 0.55 \\
montmorillonite, & tight & 0.560 & 2.7 & 0.282 & 0.74 & 0.26 \\
Wyoming & loose & 0.330 & 2.7 & 0.313 & 0.39 & 0.61 \\
illite,Fithian & tight & 0.605 & 2.6 & 0.313 & 0.75 & 0.25 \\
& loose & 0.265 & 2.6 & 0.254 & 0.39 & 0.61 \\
\hline
\end{tabular}

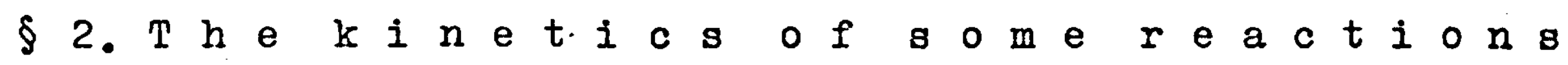
$r$ e c o r d e d i n DTA e $x$ p e r i e n t s.

Most reactions involved in DTA records belong to one of the following types

(1) loss of adsorbed water Clay $\mathrm{H}_{2} \mathrm{O} \rightarrow \mathrm{Clay}+\mathrm{H}_{2} \mathrm{O}-\Delta \mathrm{H} \mathrm{cal}$

(2) loss of lattice water $\mathrm{R}(\mathrm{OH})_{2} \rightarrow \mathrm{RO}+\mathrm{H}_{2} \mathrm{O}^{-} \Delta \mathrm{H} \mathrm{cal}$

(3) Ioss of carbon dioxide $\mathrm{RCO}_{3} \rightarrow \mathrm{RO}+\mathrm{CO}_{2}-\Delta \mathrm{H} \mathrm{cal}$

(4) oxidation reactions

(5) inversion reactions $4 \mathrm{RO}+\mathrm{O}_{2} \rightarrow 2 \mathrm{R}_{2} \mathrm{O}_{3}+\Delta \mathrm{H} \mathrm{cal}$ $R_{I} \rightarrow R_{I I} \pm \Delta H$ cal. 
The reactions $1-4$ are reactions in heterogeneous systems. NERNST and others (see $175^{\circ}$ ) have pointed out that such reactions are controlled by the rate nf diffusion of the escaping or of the entering gar.: As diffusion 18 a process of the first order, it is to be expected that the observed velocity of reaction obeys the equation of first order kinetics, $i . e$.

$$
\frac{d x}{d t}=k(m-x)
$$

where $x$ represents the quantity of material whiah reacted up to the time under consideration, $\underline{m}$ the total quantity initially present, $\underline{k}$ the reaction constant and $t$ the time.

The reactions of type 5 usually are not of the first order, as has been proved for the $\alpha \rightarrow \beta$ quartz inversion (273).

ZIMMERMAN (283) has discussed the limitations of the application of diffusion control upon heterogeneous reactions. For most reactions involved in DiA (type 1-4), however, equation 13 may be used.

MURRAY and WHITE ( 214 ! confirmed experimentally that the dehydration reactions of kaolinite, halloysite and montmorillonite might be described as unimolecular reactions, obeying equation 13. These workers made a number of dehydration experiments at constant temperature. If the logarithm of loss-in-weight was plotted against time, straight lines were obtained, as is to be expected from equation 13 in its integrated form

$$
\ln \frac{m-x}{m}=-k t
$$

The same considerations may be applied to the earlier dehydration experiments of HOULDSWORTH and COBB, and PIETERS.

However, a complication arises in the process of DTA. The reaction constant $k$ in equation 13 and 14 is strongly dependent upon temperature, as is expressed by the ARRHENIUS - van 't HOFF equation

$$
\mathbf{k}=A e^{-\frac{E}{R I}}
$$

where $\underline{E}$ represents the energy of activation, $\underline{k}$ the gas constant, $\underline{T}$ the absolute temperature and $A$ a constant with the dimension $\sec ^{-1}$

In the experiments of HOULDSWORTH, PIETERS and MURRAY and WHITE, quoted above, the temperature during dehydration was kept conotant. Consequentiy $\underline{k}$ was a constant. In DTA experiments however, the temperature during anj reaction is not constant, but 1s increasing. This implies an increase of the reaction 
constant $\underline{k}$ during heating.

For this case, equation 15 may be written

$$
\text { In } k=-\frac{E}{R T}+b
$$

where $b$ stands for In $A$. Now, since the value of $\frac{E}{R}$ is a constant for any reaction, we may write

$$
\ln k=-\frac{\alpha}{T}+b
$$

The temperature $T$ in any DTA experiment is a function of the time and the heating rate $C$, as follows

$$
T=C t+T_{0}
$$

Equation 13 now becomes after substitution of $\underline{\mathrm{k}}$ and $\underline{\underline{T}}$

$$
\begin{aligned}
& \frac{d x}{m-x}=e^{-\frac{\alpha}{c t+T_{0}}+b} d t \\
& \ln \frac{m}{m-x}=e^{b} \int_{e}^{t}-\frac{\alpha}{c t+T_{0}} d t
\end{aligned}
$$

Putting $\frac{\alpha}{C t+T_{0}}=\frac{1}{u}$ we get, since $t=\left(\alpha u-T_{0}\right) / C$,

$$
\begin{aligned}
\ln \frac{m}{m-x}=\frac{\alpha e^{b}}{C} \int_{T_{0} / \alpha}\left(C t+T_{0}\right) / \alpha & -\frac{1}{u} d u . \\
& =\frac{\alpha e^{b}}{2.303 c} \int_{\frac{2.303 T_{0}}{\alpha}}^{\frac{2.303\left(C t+T_{0}\right)}{\alpha}} 10-\frac{1}{u} d u .
\end{aligned}
$$

or, solving for $x$,

$$
x=m\left(1-e x p-\frac{k e^{b}}{2.303 C} \frac{2.303\left(C t+T_{0}\right)}{\alpha} 10-\frac{1}{\frac{2.303 T_{0}}{\alpha}} d u\right)
$$

If the experimental conditions $\underline{C}$ and $T o$ and the constants of the reaction $\underline{\alpha}=Q / 2.303 R$ and $\underline{b}$ are known, values of $\underline{x}$ may be computed for any time $t$ in the experiment. Tableg for the integral

$$
H(r)=\int_{r_{1}}^{r_{2}} 10^{-\frac{1}{u}} d u
$$

are given by SHERMAN (Ind.Eng.Chem.28:1027 (1936)) for values of $r=0.05$ to $r=0.175$ and by JAHNKE and EXDE for higher values of $\mathbf{r}$. 
In order to avold the difficulties with the handing of equation 17, it is better to use the equation of the reaction isochore of van 't HOFF. This equation describes tha relation of the equilibrium constant $K$ as a function of temperature and the heat of reaction $Q$

$$
\frac{\mathrm{d} \ln K}{\mathrm{dT}}=\frac{\mathrm{Q}}{\mathrm{RT}^{2}}
$$

Equation 18 is essentially the same as equation 15. However, $K$ and $Q$ in equation 18 are better accessible than $k$ and $E$ in equation 15.

The way of applying equation 18 to actual reactions was given by NERNST $\left(216^{a}\right)$ when he formulated the third law of thermodynamics.

NERNST states that the heat of reaction $\underline{Q}$ depends upon the temperature at which the reaction takes place. The relation may be expressed as follows

$$
Q_{T}=Q_{0}+\alpha T+\beta T^{2}+\gamma T^{3}+\ldots \ldots
$$

where $Q_{0}$ represents the heat of reaction near the absolute $z e-$ ro point of the temperature scale.

Sulstitution of equation 19 in 18 and subsequent integration leads to

$$
\ln R=-\frac{Q_{0}}{R T}+\frac{\alpha}{R} \ln T+\frac{\beta}{R} T+\frac{\gamma}{2 R} T^{2}+\ldots+I
$$

where I represents the integration constant. In his book ( $p$. 739-742) NERNST derives for $I$

$$
I=\sum \nu \varepsilon
$$

where $\Sigma$ vis the sum of the molecules resulting from the reaction minus the sum of the molecules entering in the reaction and $\mathcal{E}$ is the so called "chemical constant".

For heterogeneous equilibria (reactions of type 1 - 4) equation 20 likewise holds, but $K$ than repreeents the equilibrium constant of the heterogeneous system. The difficulty in the application of equation 20 lies in the evaluation of the quantities $Q_{0}, \alpha, \beta, \gamma \ldots .$. The quantities $\alpha, \beta \ldots$ refer to the tem perature dependency of the specific heat of the substance under consideration.

However, for most substances no measurements are available of the specific heat in low and high temperature ranges. So it is neccessary to use some approximations in equation 20.

NERNST (p. 741-742) derives as approximated formula:

$\ln K=-\frac{0}{R T}+\sum \nu \frac{3.5}{B} \ln T+\frac{\beta}{B} T+\frac{\gamma}{2 R} T^{2}+\ldots$ 
Conversion to decimal logarithms and substitution of $R=1.98$ cal leads to

$\log K=-\frac{Q}{4.57 T} \cdot \frac{1}{T}+\sum \nu 1,75 \log T+\frac{\beta}{4.57 T} T+\frac{\gamma}{9.142} T^{2}+\sum \nu \varepsilon^{\prime}$

The second approximation is the omission of the terms containing $\beta$ and $\gamma$, as these are very small in comparison with the other terms. So the final approximation leade to

$\log K=-\frac{\cdot Q}{4.57 T} \cdot \frac{1}{T}+\sum \nu \cdot 1.75 \log T+\Sigma \nu \varepsilon^{\prime}$

In reactions where gases originate it is more convenient to use the partial vapour pressures of the reactants, instead of the concentrations in computing $K$. Equation 24 than converts to

$\log p=-\frac{Q}{4.57 T} \cdot \frac{1}{T}+\sum \nu \cdot 1.75 \log T+\sum \nu \varepsilon$

This equation may prove to be a very useful one, as all quantities are independently accessible. The direct proof of the validity of equation 25 is found in the measurements of the vapour pressure of the volatile component as a function of temperature. Such measurements are available for a number of carbonates (DEBRAY, ZATADSKI, a.0.) and salts containing water of crystallization (e.g. $\mathrm{Na}_{2} \mathrm{SO}_{4} \cdot 10 \mathrm{H}_{2} \mathrm{O}$ ). PIETERS made accurate measurements of $p=f(T)$ with kaolinites, while the measurements of MURRAY and WHITE likewise are very useful, as we have seen akove.

From all these measurements it appears that nearby straight lines are obtained if $\log \mathrm{p}$ is plotted against $1 / \mathrm{T}$. The term containing $\log \mathrm{T}$ in equation 25 does not interfere seriously in the high temperature range, so that only very slight deviations from the straight line are seen in the $\log p-1 / T$ plots. In fig. $18 \log \mathrm{p}$ is plotted against $1 / \mathrm{T}$, computed from the data given by PIETERS.

The observed delay of reactions of type 1 - 4 as recorded in DTA, may be understood now. Because these reactions result from monovariant equilibria, the vapour pressure of the gascomponent in the direct surroundings of the clay determines the rate of reaction.

The reaction starts (in types 1 - 3) as soon as the vapour pressure of the volatile component in the sample exceeds the vapour pressure of that component in the furnace atmosphere. After the start, however, the reaction does not expire at once, 
because its course is inhibited by the gas which is formed. The maximum rate of reaction occurs at the peak temperature. It is assumed that at the peak temperature the vapour pressure of the volatile component equals 1 atmosphere, all the air in the reaction vessel being replaced by the evasive component.

The assumption that at the maximum rate of reaction $p$ equals $1 \mathrm{~atm}$. may be adduced by a small calculation. If 1 gram of kaolinite $\left(13 \% \mathrm{H}_{2} 0\right)$ takes a volume of $0.7 \mathrm{cc}$ in a sample hole, the volume of air enclosed is about $0.3 \mathrm{cc}$. The volume of the water vapour, vanishing upon the dehydration of the kaolinite sample, equals $0.13 \times 22220 / 18=160 \mathrm{cc}$. So it is seen that the volume of the originating water vapour is far in excess over the volume of the air space in the sample hole. Therefore it is justified to assume, that already before the peak temperature is reached, the originating gas fully replaces the air, present in the sample hole.

In the quantitative application of equation 25 to the delay of reactions, as observed in DTA experiments, it seems con-

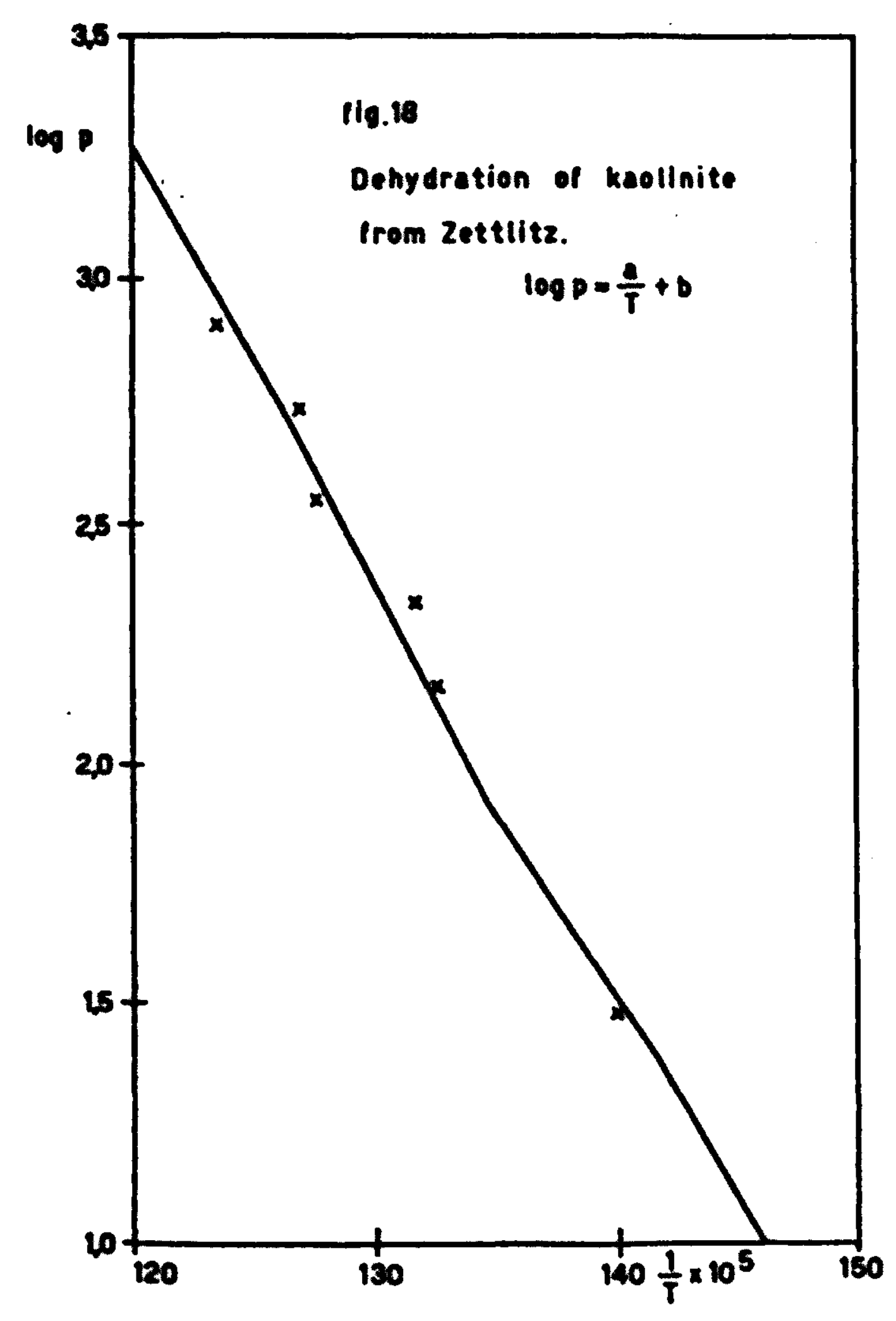




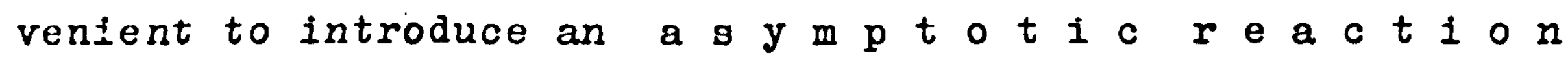
t e m e r a $t$ u $r$ e $\hat{T}$. We define $\hat{T}$ as the absolute temperature at which the reaction starts and finishes in a time approaching infinite, under a heating rate $\mathrm{C}=0$, and under a vapour pressure of the volatile component approaching zero. For a number of reactions $\hat{T}$ is indicated in chapter $V$, table 12.

The deviation of the real (observed) reaction temperatures from the asymptotic reaction temperatures may be calculated according to equation 25

$$
\begin{aligned}
\Delta \mathrm{T}=\mathrm{T}_{\text {obs }}-\hat{\mathrm{T}} & =\frac{\mathrm{Q}}{4.57 T(\mathrm{~b}-\log \mathrm{p})}-\frac{\mathrm{Q}}{4.571 \mathrm{~b}} \\
& =\frac{\mathrm{Q} \log \mathrm{p}}{4.577 \mathrm{~b}(\mathrm{~b}-\log \mathrm{p})}
\end{aligned}
$$

where $\underline{b}$ is written for the sum $(\Sigma \nu .1 .75 \log \mathrm{T}+\Sigma \nu \varepsilon)$.

When $\mathrm{p}$ is written in $\mathrm{mm} \mathrm{Hg}$, the factor $\underline{b}$ equals:

$\mathrm{b}=\Sigma \nu .1 .75 \log \mathrm{T}+\sum \nu \varepsilon+\log 760$

The value of $\Sigma v$ is read from the reaction equation as it represents the sum of the moles resulting from the reaction. Ihus for

$\Sigma \nu=2-1=1$

$$
\mathrm{CaCO}_{3} \rightarrow \mathrm{CaO}+\mathrm{CO}_{2}
$$

Values of the chemical constant $\varepsilon$ are given by NERNST $\left(216^{\mathrm{a}}\right.$ ) for a number of gases and an excerpt. of his table is represented here.

Table 10.

Chemical constants for some gases (from NERNST $\left(216^{a}\right)$ )

\begin{tabular}{|l|l|l|l|l|l|}
\hline $\mathrm{H}_{2}$ & 1.6 & $\mathrm{CO}_{2}$ & 3.2 & $\mathrm{NH}_{3}$ & 3.3 \\
$\mathrm{O}_{2}$ & 2.8 & $\mathrm{H}_{2} \mathrm{O}$ & 3.6 & $\mathrm{SO}_{2}$ & 3.3 \\
\hline
\end{tabular}

With the aid of these constants, values of $\underline{b}$ may be computed with equation 27. It should, however, be born in mind that $\underline{b}$ is not a true constant, but is dependent of $\log T$. As the variation of $\log \mathrm{T}$ in the high temperature ranges.is only small, b varies only slightly.

In the table 11 some values of $\underline{Q}$ and $\underline{b}$ are given for reactions important in DTA of clays. 
Values of the heat of reaction $Q$ in cal, per mole and in cal. per gram of some important reactions, and of the factor $\underline{b}$.

mineral

quartz

goethite

gibbsite.

kaolinite

halloygite

illite

montmorillonite

calcite

aragonite.

siderite reaction

inversion

dehydration

do

do

do

do

do

loss of $\mathrm{CO}_{2}$

inversion

loss of $\mathrm{CO}_{2}$

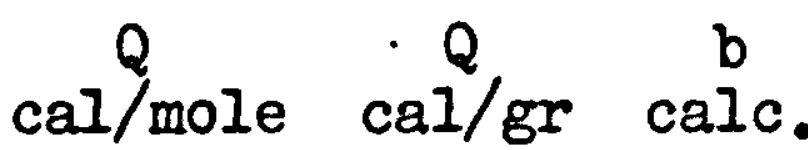

Iit. callmole cal/gr calc. reference

The values of $Q$ marked with an asterisk + are calculated from thermal data, with the aid of equation 25.

- It should however be emphasized that the application of equations 25 and 26 to DTA curves for most minerals is only approximative, as the correct values of $Q$ are lacking. The need for further basic research in this respect is stressed.

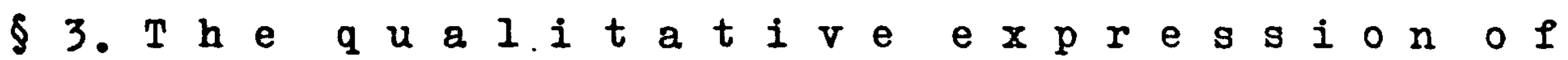
DTA c u r ves; p e a $k$ s h ifting:\%

It was seen in $\$ 1$ and 2 that the delay in reactions of type 1 - 3 in DTA experiments has two causes:

1. The gradually increasing partial vapour pressure of the volatile component in the reaction environment, once the reaction has started.

2. The difference in properties, relating to heat transfer, between clay sample and inert sample.

As a summation of these two effects the peak shift amounts to

$$
T_{\text {obs }}-\hat{T}=\frac{r^{2}}{4} c\left(1 / f a-1 / f^{\prime} a^{\prime}\right)+\frac{Q \log p}{4.571 b(b-\log p)}
$$

However, the influence of the nature of the sample holder is not accounted for in equation 28. As is seen from fig. 10 the reaction temperatures are only slightly influenced by the 
nature of the sample block. The peak area on the contrary is greatly influenced by the kind of sample holder.

Besides the reaction temperatures $T_{1}$ and $T_{p}$, the peak area is another characteristic of DTA curves. In chapter III it was already seen how the peak area is influenced by several factors. Fig. 19 shows how the peak area is influenced by the velocity of temperature rise.

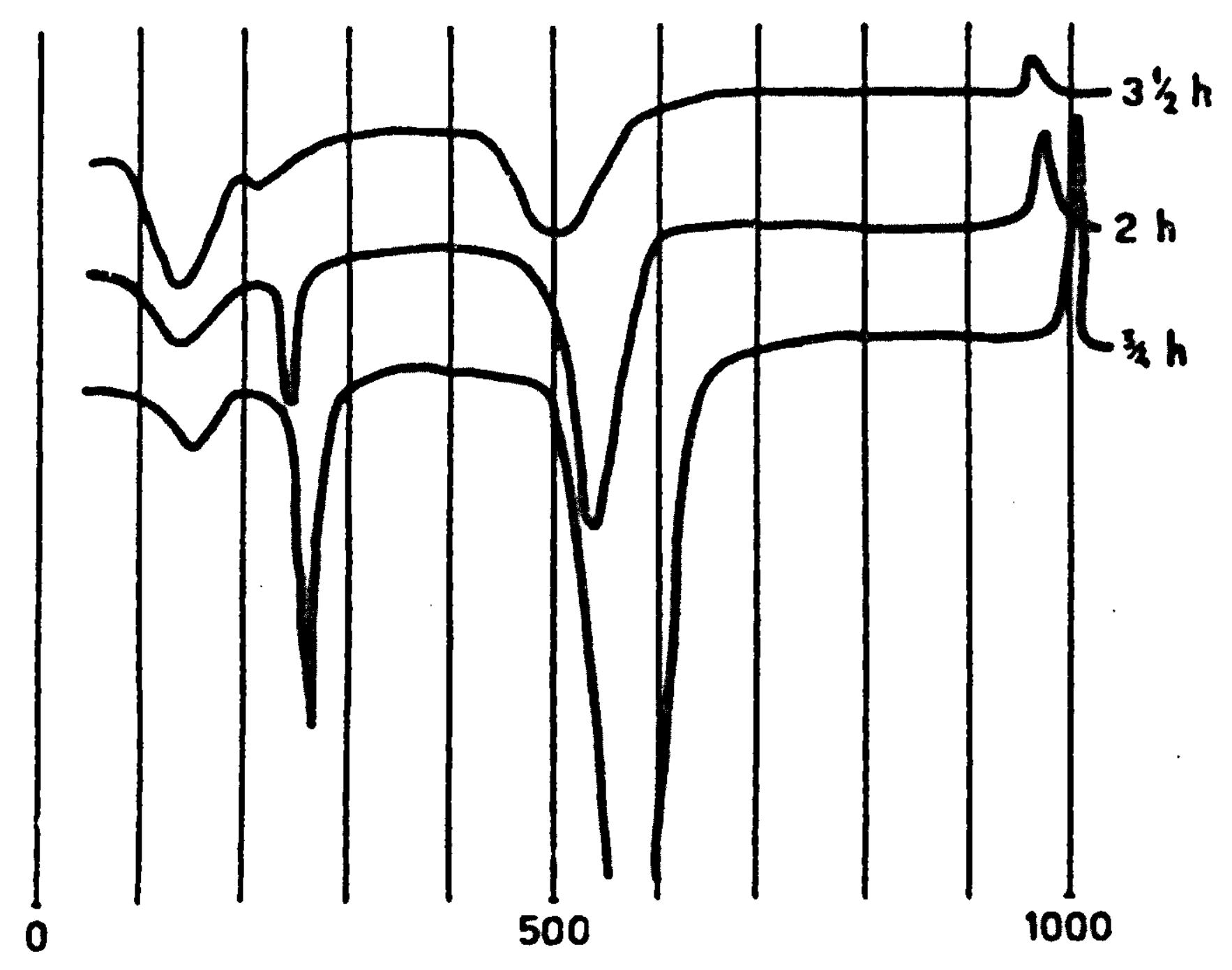

Fig. 19. Influence of the velocity of temperature rige upon the DTA curves of Moengo clay.

The gibbsite present in the clay from Moengo, Surinam, is hardly observeable in experiments with small heating rateg, whereas its presence is clearly shown in experiments with large heating rates.

In fig. 10 and in $\S 3$ of chapter III it was shown how the nature of the sample block influences the peak area.

Theoreticaliy the influence of the sample block may be evaluated as follows. If an $e \mathrm{n} d \mathrm{t} h \mathrm{e} r \mathrm{~m}$ a $l$ reaction occurs in the clay, the heat of reaction must be supplied from the sample block to the reactant. The quantity of heat which is supplied to the samples per unit of time depends upon the temperature gradient in the block and the heat conductivity $\lambda$ as follows

$$
\frac{d Q}{d t}=\lambda F \frac{d T}{d z}
$$

where $F$ is the area under consideration, through which the heat 
In ceramic blocks $\lambda$ is small, in nickel blocks large. The heat supplied per unit of time ( $\left.\frac{d Q}{d t}\right)$ is the same in one furnace for all types of blocks, provided the heat capacity of tile sample block is negligible with respect to the heat capacity of the active furnace material.

So as equation 29 holds for both ceramic and metal blocks, $\frac{d T}{d z}$ should be larger in the ceramic blocks than in metal blocks. In other words: the records of endothermal reactions are more pronounced in ceramic blocks than nickel blocks.

. In $e x \circ t h$ e $r$ a $l$ reactions in the clay sample the heat effect originates in the clay itself. Unlike endothermal reactions, where the heat of reaction is taken up from the block, there is in exothermal reactions an extra quantity of heat originating in the sample. Endothermal reactions thus are delayed with respect to heat supply, while exothermal reactions gain with respect to the heat supply.

Because nickel blocks have a larger heat transfer coefficient than ceramic blocks, the initiation of exothermal reactions is favoured in nickel blocks. Once an exothermal reaction has started, it accelerates itself and thus the time of reaction is smaller in nickel blocks than in ceramic blocks (see fig. 10). Consequently peak heights are greater in metal blocks than in ceramic blocks.

Fig. 20 gives a schematic representation of the course of temperature difference as a function of time and reaction rate.

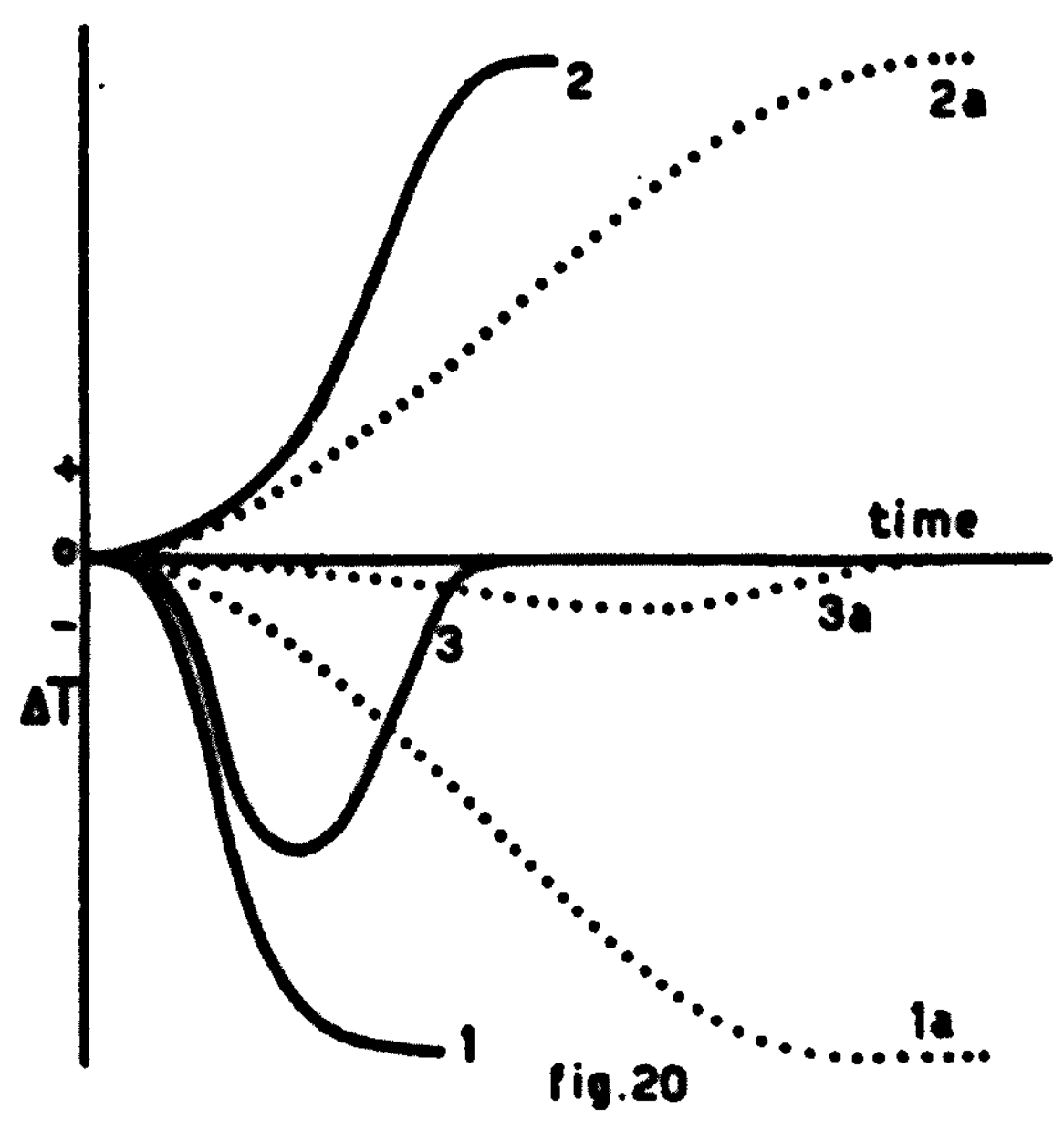


The line 1 represents the course of the temperature difference between clay sample and inert sample during an endothermal reaction, for the idealized case, that no heat exchange with the environment should take place during the reaction. In fact, however, such heat supply does take place (Iine 2), but the temperature course of the heat supply is delayed with respect to the course of the reaction. The net effect is represented by line 3 , showing the difference between the values of $\Delta T$ of $11-$ nes 1 and 2 for every value of $t$. In 3 is the factual DTA curve for an endothermal reaction.

The set of dotted lines represent an endothermal reaction, but here the heating rate of the furnace was assumed to be much smaller. Consequently, the line $2^{8}$ is only slightly delayed with respect to $1^{a}$. For a complete understanding of the differential temperature line both gross effects (lines 1 and 2 respectively $1^{a}$ and $2^{a}$ ) should be considered.

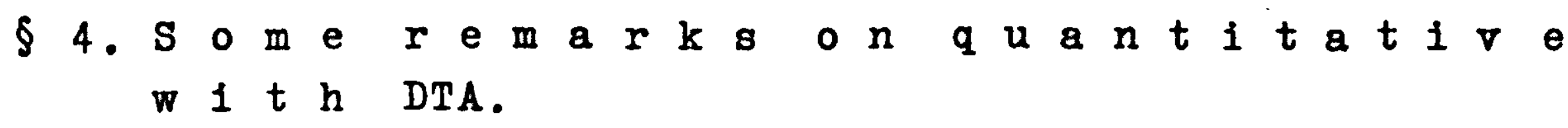

The problem in quantitative DTA is to find a relation between any measurable item of the curves and the percentage of the unknown component in a mixture. In chapter $1 \S 4$ was seen how different authors attacked the problem.

Most workers nowadays $(7,26,39,135,174,219,254,271$, 276) consider the area under the peaks as a measure of the quantity of reacting material. So

$$
\int \Delta \mathrm{T} d t=f(m)
$$

The various derivations given (a.0. by SPEIL, KULP and KERR, and VOID), however, are not without defects.

As is seen from fig. 20 the area under the differential temperature peak is equal to the difference of the area under the curves 1 and 2 , resp. $1^{a}$ and $2^{a}$.

The area under the curves 1 or $1^{\text {a }}$ may be obtained as folIows.

For any reaction, accompanied by a heat effect, one has

$$
\Delta T_{1}=\frac{Q x}{c m}
$$

where $Q$ is the heat of reaction (per gram), $x$ is the quantity of reacting material, and $\mathrm{cm}$ is the heat capacity of the cell plus contents.

The term cm may be considered as the sum of the heat capa- 
c1ties of the various substances, which are raised or lowered in temperature during the reaction

$$
c m=c_{1} m_{1}+c_{2} m_{2}+\ldots \ldots
$$

As $x$ in equation 31 is a function of time, according to equation 13 and 16, we may write for the area under curve 1 of Iig. 20

$$
\int_{0}^{t} \Delta T_{1} d t=\int_{0}^{t} \frac{Q}{c_{1} m_{1}+c_{2} m_{2}+\ldots} m_{1}\left(1-\exp \left[-e^{b} \int_{0}^{t} e^{-\frac{\alpha}{c t+T_{0}}} d t\right]\right) d t
$$

The area under the curves 2 and $2^{a}$ between the time limits $t=0$ and $t=t$ may be represented with close approximation as follows

$$
\int_{0}^{t} \Delta \mathrm{T}_{2} d t=\frac{Q \mathrm{~m}_{1}}{\mathrm{c}_{1} \mathrm{~m}_{1}+\mathrm{c}_{2} \mathrm{~m}_{2}+\ldots} \int_{0}^{t} \frac{1}{2} d t
$$

The net area of the recorded curve, represented as curve 3 or $3^{a}$ in $11 \mathrm{~g} .20$ thus is equal to the difference of equations 33 and 34 .

$$
\int_{0}^{t} \Delta \mathrm{T}_{3} d t=\frac{1}{2}\left(\frac{Q}{c_{1}}+\frac{Q_{1}}{c_{2} m_{2}}\right)\left\{t-\int_{0}^{t} \exp \left[-e^{b} \int_{0}^{t} \exp \left[-\frac{\alpha}{c t+T_{0}}\right] d t\right] d t\right\}
$$

where $t$ is the time of reaction.

Equation 35 shows how the area under the peak depends upon the percentage of reacting material $\left(m_{1} / m_{2}\right)$, upon the time of reaction and upon the constants of the experiment $\underline{C}$ and $\underline{Q}$.

The time of reaction also depends upon the heating rate $c$, as follows

$$
t=\frac{q m}{\left(c_{1} m_{1}+c_{2} m_{2}+\ldots\right)} \frac{1}{c}
$$

where $q$ is the number of calories, needed to raise the temperature of the cell plus contents from $\mathrm{T}_{1}$ to $\mathrm{T}_{f}$.

That $t$ is inversely proportional to $C$ was already seen in the values quoted in table 2 .

For accurate quantitative analysis with the differential thermal method, the heating rate should be kept the same in the various experiments. The peak area is not independent of the heating rate as SPEII and coworkers concluded, see fig. 19. 


\section{THE COMPARISON OF DTA RECORDS OBTAINED}

\section{WITH DIFFERENT EQUIPMENTS}

The general equation for the comparison of reaction temperatures in curves obtained with different DTA equipments is

$$
T=T_{b s}-\frac{r^{2}}{4} c\left(1 / f a-1 / f^{\prime} a^{\prime}\right)-\frac{Q \log p}{4.571 b(b-\log p)}
$$

The units which are employed are

$\underline{\hat{T}}$ and $\mathrm{T}_{\mathrm{obs}}$ in ${ }^{\mathrm{O}_{\mathrm{K}}}$ or ${ }^{\mathrm{O}} \mathrm{C}$

$\underline{r}$ in $\mathrm{cm}$

$\overline{\mathrm{C}}$ in ${ }^{\circ} \mathrm{C}$ sec $^{-1}$

f dimensionless

$\underline{a}$ and $\underline{a^{\prime}}$ in $\mathrm{cm}^{2} \mathrm{sec}^{-1}$

$\underline{Q}$ in cal.mole $\mathrm{e}^{-1}$

$\mathrm{p}$ in $\mathrm{mm} \mathrm{Hg}$.

The meaning of the symbols is the same as in chapter IV.

In the application to dehydration reactions $p$ represents the partial vapour pressure of water in the reaction vessel at the temperature $\mathrm{T}_{\text {obs }}$ under consideration. In the application to the decomposition reactions of the carbonates $p$ represents the partial vapour pressure of carbon dioxide in the reaction vessel at $\mathrm{T}_{\mathrm{obs}_{\mathrm{g}}}$. At the peak temperature $\mathrm{p}$ equals $760 \mathrm{~mm}$ Hg for all reactions accompanied by 1083 in weight, as was outlined in chapter IV.

In the application to inversion reactions the last term of equation 36 equals zero, as in such reactions no vapour pressures interfere.

In the application of the equation to experiments where the furnace temperature was measured in the centre of the clay sample itgelf, the term:

$$
\frac{r^{2}}{4} C\left(1 / f a-1 / f^{\prime} a^{\prime}\right)
$$

equals zero, as $a=a^{\prime}$ in these cases.

The assymptotic reaction temperatures $\hat{\mathrm{T}}$ may be obtained in different ways: first of all from very accurate static dehydration experiments, secondly from measurements of the vapour presoure as a function of temperature, and thirdly from NERNST'B equation given in chapter IV as equation 25. 
In the cases of calcite and kaolinite the three ways of computing $\hat{T}$ lead to sensibly the same results. For other clay. minerals there is a considerable lack in our knowledge of $p$ as a function of $\underline{T}$, and of the heats of reaction $Q$. For these minerals $\hat{\mathfrak{T}}$ may be obtained with some accuracy only from static dehydration experiments.

In table 12 values of $\hat{\mathrm{T}}$ for a number of reactions are summarized.

As both the peak temperature $\left(\mathrm{p}_{\mathrm{T}} \mathrm{s}\right)$ and the temperature of initiation $\left({ }_{1} T_{\text {obs }}\right)$ of the reactions are considered in the $11-$ terature, the conversion of both temperatures will be discussed here.

In the application of equation 36 the values of the conotants $Q$ and $b$ are taken from table 11, chapter IV.

a. Cor e c t $i$ on of $i^{T}$ obs $^{*}$

The partial vapour pressure of water $(p)$ in the furnace atmosphere determines the value of the last term in equation 36 . Unfortunately $\mathrm{p}$ depends upon the weather conditions prevailing and thus is subject to variation.

In the Netherlands the watersaturation of the air at $18^{\circ} \mathrm{C}$ is $70 \%$ on the average. Hence the partial vapour pressure of water in the air is about $13 \mathrm{~mm} \mathrm{Hg}$, and $\mathrm{log} p$ equals 1.114. We use this value in our calculations.

As an example we will calculate the correction of $i^{T}$ obs for kaolinite. The constants of the reaction are $Q=300 \mathrm{cal} / \mathrm{gr}=$ $300 \times 258 \mathrm{cal} / \mathrm{mole} ; \mathrm{b}=18.84$.

In a given experiment with kaolinite from Zettlitz values were: $r=0.4 \mathrm{~cm} ; C=18.5{ }^{\circ} \mathrm{C}$ per min. $=0.31{ }^{\circ} \mathrm{C}$ per sec $; f=0.7$, $f^{\prime}=0.8 ; 1 / a=870,1 / a^{\prime}=430 \mathrm{sec} \mathrm{cm}^{-2} \cdot i^{\mathrm{T}}$ obs was $480^{\circ} \mathrm{C}$.

If these values are substituted in equation 36 we get:

$$
\hat{\mathrm{T}}=480-9-57=414{ }^{\circ} \mathrm{C}
$$

The expected value of $\hat{\mathrm{T}}$ was $420 \pm 10^{\circ} \mathrm{C}$ as follows from table 12. The calculated and the expected value of $\hat{\mathbb{T}}$ are in close agreement.

b. Cor r e c t 1 on $01 p^{T}$ obs $^{\circ}$

For the conversion of $\mathrm{p}^{\mathrm{T}}$ obs to $\hat{\mathrm{T}}$ equation 36 likewise is used. However $p=760 \mathrm{~mm} \mathrm{Hg}$ at the peak temperature and $\log \mathrm{p}=$ 2.881 .

In the eame experiment as queted above the $\mathrm{p}^{\mathrm{T}}$ obs was $590^{\circ} \mathrm{C}$. Substitution of the constants of the reaction and of the con- 
Values of $\hat{T}$ for various reactions of clay minerais, in absolute temperature scale and Celsius temperaturs scale.

\begin{tabular}{|c|c|c|c|c|}
\hline Mineral & $\begin{array}{l}\text { Type of } \\
\text { reaction }\end{array}$ & ${ }^{\circ} \mathrm{C}$ & ${ }^{O_{K}}$ & $\begin{array}{l}\text { Iiterature } \\
\text { references }\end{array}$ \\
\hline $\begin{array}{l}\text { quartz } \\
\text { diaspore } \\
\text { gibbsite } \\
\text { goethite } \\
\text { kaolinite } \\
\text { halloysite } \\
\text { illite } \\
\text { montmorillonite } \\
\text { beidelite } \\
\text { gapomite } \\
\text { nontronite } \\
\text { calcite } \\
\text { magnesite } \\
\text { dolomite }\end{array}$ & $\begin{array}{c}\text { inversion } \\
\text { dehydration } \\
\text { do } \\
\text { do } \\
\text { do } \\
\text { do } \\
\text { do } \\
\text { inversion } \\
\text { dehydration } \\
\text { invergion } \\
\text { dehydration } \\
\text { do } \\
\text { do } \\
\text { do } \\
\text { do } \\
\text { loss of } \mathrm{CO}_{2} \\
\text { do } \\
\text { do } \\
\text { do }\end{array}$ & $\begin{array}{l}573 \\
460 \\
190 \\
240 \\
480 \\
235 \\
420 \\
905 \\
440 \\
905 \\
310^{+} \\
510^{+} \\
370^{+} \\
490^{+} \\
370^{+} \\
610 \\
400 \\
500 \\
550\end{array}$ & $\begin{array}{l}846 \\
733 \\
463 \\
513 \\
753 \\
508 \\
693 \\
1178 \\
713 \\
1178+ \\
583^{+} \\
783^{+} \\
643^{+} \\
763^{+} \\
643^{+} \\
883 \\
673 \\
773 \\
823\end{array}$ & $\begin{array}{c}18,78,86, .273 \\
224 \\
224 \\
224 \\
224 \\
224 \\
55,147,160,285 \\
55,147,285 \\
224 \\
- \\
224 \\
224 \\
224 \\
224 \\
224 \\
80,224 \\
77,224 \\
77,224 \\
77,224 \\
77,24\end{array}$ \\
\hline
\end{tabular}

Accuracy for all temperatures $\hat{\mathrm{T}} \pm 10^{\circ}$, except for quartz where the accuracy is $846 \pm 2^{\circ}$, and for the minerals marked with + where the accuracy is $\hat{\mathrm{T}} \pm 20^{\circ}$.

stants of the equipment in equation 36 leads to

$$
\mathrm{T}=590-9-162=418{ }^{\circ} \mathrm{C} \text {. }
$$

The calculated value of $\hat{T}$ is gensibly the same as the expected value of $420 \pm 10^{\circ} \mathrm{C}$.

$$
\begin{aligned}
& \text { c. A p p I i a t } 1 \text { on to qualitative } \\
& a \text { in a } 1 \text { y } 81, a \text {. }
\end{aligned}
$$
noted of rather strong intensity, with the characteristics

$$
1_{\text {obs }}=705{ }^{{ }^{\circ} \mathrm{C} ;} \text { p }_{\text {obs }}=895{ }^{\circ} \mathrm{C} \text {. }
$$

The presence of calcite was expected, as the clay reacted strongly with hydrochloric acid. The constants of the experiment were as follows: $r=0.3 \mathrm{~cm} ; C=11^{\circ}$ per $\min =0.18^{\circ}$ per sec.; $\rho=0.8, \rho^{\prime}=0.8 ; a=1.44^{\circ} 10^{-3}$ (estimated from composition), $a^{\prime}=2.326 \cdot 10^{-3} \mathrm{~cm}^{2} \mathrm{sec}^{-1}$.

Onder the assumption that calcite was present, $Q$ was taken $42500 \mathrm{cal}$ mole $e^{-1}$ and $b=11.03$. 
With these values substituted in equation 36 , was found to be equal to

$$
\begin{aligned}
\hat{\mathrm{T}} & =895-\frac{0.09}{4} 0.18(870-530)-\frac{42500.2 .881}{4.571 \cdot 11.03^{\circ} \cdot 1.15}= \\
& =895-1.5-297=597^{\circ} \mathrm{C} .
\end{aligned}
$$

As read from the table $\hat{\mathrm{T}}$ of calcite equals $610 \pm 10^{\circ} \mathrm{C}$ so the assumption that calcite was present in the clay proved to be justified.

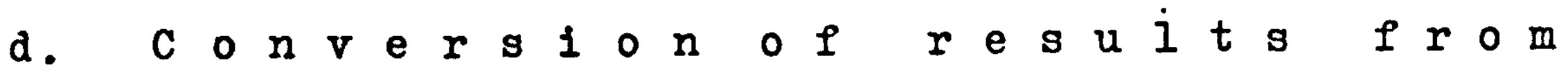

$$
\begin{aligned}
& \text { d } 1 \text { f e } r \text { e } t \text { e } q u 1 p m e n t s \text {. }
\end{aligned}
$$

A number of rung were made with the same sample of clay, submitted to DTA in different equipments. The results of these experiments, together with the constants of the equipments, are summarized in table 13.

Tabie 13

\begin{tabular}{|c|c|c|c|c|c|c|c|c|}
\hline Clay sample & $\begin{array}{l}\text { mun } \\
\text { no. }\end{array}$ & \multicolumn{2}{|c|}{$\underset{\mathrm{mm}}{\mathrm{block}} \mathrm{h}$} & C & $i_{0}^{T} o_{C b s}$ & $\mathrm{p}_{\mathrm{O}}^{\mathrm{T}}{ }_{\mathrm{Cbs}}$ & $\mathcal{I}$ & $f^{\prime}$ \\
\hline $\begin{array}{l}\text { Illite, } \\
\text { Winsum. } \\
\text { Kaolinite, } \\
\text { Ranau. } \\
\text { Kaolinite, } \\
\text { Kaaden. } \\
\text { Montmorilio } \\
\text { nite, Wyo. }\end{array}$ & $\begin{array}{l}219 \\
234 \\
215 \\
218 \\
216 \\
\text { Par } \\
82 \\
11 \\
11 \\
130 \\
\text { Par }^{+} \\
128 \\
191 \\
\text { Par }^{+} \\
154 \\
\text { Par }^{+} \\
342 \\
105 \\
\text { Par }^{+}\end{array}$ & $\begin{array}{l}3 \\
6 \\
7 \\
8 \\
8 \\
7 \\
6 \\
6 \\
8 \\
7 \\
8 \\
8 \\
7 \\
6 \\
7 \\
3 \\
8 \\
7\end{array}$ & $\begin{array}{r}12 \\
12 \\
15 \\
12 \\
12 \\
25 \\
15 \\
6 \\
12 \\
25 \\
12 \\
12 \\
25 \\
6 \\
25 \\
12 \\
12 \\
25\end{array}$ & $\begin{array}{r}15 \\
21 \\
19 \\
22 \\
20 \\
11 \\
7 \\
17 \\
13 \\
11 \\
9 \\
22 \\
11 \\
18 \\
12 \\
12 \\
7 \\
11\end{array}$ & $\begin{array}{c}440 \\
455 \\
455 \\
460 \\
455 \\
445 \\
480 \\
485 \\
480 \\
490 \\
440 \\
445 \\
440 \\
- \\
550 \\
550 \\
600\end{array}$ & $\begin{array}{l}555 \\
570 \\
575 \\
595 \\
605 \\
630 \\
515 \\
530 \\
535 \\
570 \\
565 \\
595 \\
610 \\
565 \\
610 \\
675 \\
665 \\
720\end{array}$ & $\begin{array}{l}0.8 \\
0.9 \\
0.6 \\
0.5 \\
0.5 \\
0.4 \\
0.9 \\
0.7 \\
0.5 \\
0.4 \\
0.9 \\
0.7 \\
0.4 \\
0.9 \\
0.4 \\
0.7 \\
0.9 \\
0.4\end{array}$ & $\begin{array}{l}0.8 \\
0.9 \\
0.6 \\
0.5 \\
0.4 \\
0.4 \\
0.9 \\
0.7 \\
0.5 \\
0.4 \\
0.9 \\
0.7 \\
0.4 \\
0.9 \\
0.4 \\
0.7 \\
0.9 \\
0.4\end{array}$ \\
\hline
\end{tabular}

Comparative results of some runs in different equipments with identical samples.

${ }^{+}$) Runs made by Melle, S.Caillere. Lab.d.Minéralogie, Paris V.

From the $T_{i}$ and $T_{p}$ 's given in table 13 the assymptotic reaction temperatures were computed for the cases where a and $\underline{f}$ were known to a close approximation. The calculated assymptotic reaction temperatures are given in table 14 and compared with the expected values. 
It is seen that with the kaolinites the best agreement is found between calculated and expected values of $\hat{T}$.

Table 14.

Comparison of expected and calculated assymptotic reaction temperatures; data from table 13. Relative humidity in Paris 55\% at $18^{\circ}$, in Tageningen in most cases $70 \%$ at $18^{\circ}$.

\begin{tabular}{|c|c|c|c|c|}
\hline Sample & run & $\begin{array}{l}\text { Assymptotic } \\
\text { Calc.from } \mathrm{T}_{\mathrm{p}}\end{array}$ & $\begin{array}{l}\text { reaction tem } \\
\text { Calc.from } T_{1}\end{array}$ & $\begin{array}{l}{ }^{\circ} \mathrm{C} \\
\text { Expected }\end{array}$ \\
\hline \multirow{6}{*}{$\begin{array}{c}\text { Kaolinite, } \\
\text { Banka. }\end{array}$} & 219 & 399 & 402 & $420 \pm 10$ \\
\hline & 234 & 406 & 413 & do \\
\hline & 215 & 408 & 414 & do \\
\hline & 218 & 418 & 410 & do \\
\hline & 216 & 420 & 415 & do \\
\hline & Par & 435 & 415 & do \\
\hline \multirow{4}{*}{$\begin{array}{l}\text { Illite, } \\
\text { ilinsum. }\end{array}$} & 82 & 330 & - & $320 \pm 20$ \\
\hline & 11 & 360 & - & do \\
\hline & 130 & 365 & - & do \\
\hline & Par & 350 & - & do \\
\hline \multirow{3}{*}{$\begin{array}{c}\text { Kaolinite, } \\
\text { Ranau. }\end{array}$} & 128 & 408 & 408 & $420 \pm 10$ \\
\hline & 191 & 418 & 412 & do \\
\hline & Par & 415 & 415 & do \\
\hline \multirow{5}{*}{$\begin{array}{l}\text { Xaolinite, } \\
\text { Kaaden. } \\
\text { gontmorillonite, } \\
\text { Wyo. }\end{array}$} & 154 & 407 & - & do \\
\hline & Par & 425 & - & do \\
\hline & 342 & 505 & 520 & $510 \pm 20$ \\
\hline & 105 & 498 & 512 & do \\
\hline & Par & 545 & 560 & do \\
\hline
\end{tabular}

With illite and montmorillonite the agreement is worse, mainly due to fact that the various thermal constants of the clay (cf. equation 36) were only known as approximations. 


\section{SOME APPLICATIONS OF DIFFERENTIAL THERMAL ANALYSIS TO PEDOLOGY}

With the recommendations at hand, indicated in chapter III, a number of separate problems have been attacked, the results of which are communicated in the next paragraphs.

\$1. The a p 1 i c a t 1 on of DTA to c l a y se p a r a $t$ e of $K-f i x$ a ting soils.

The minerals, nowadays known for their ability to bind $\mathrm{K}$ in a non-exchangeabile form, are illites, vermiculites and montmorillonites $(15,93,124)$. The fixation of $\mathrm{K}$ in the montmorillonites is known as a slow fixation (243); the fixation in illites and vermiculites as a quick fixation. Both types of fixation are enhanced by alternate wetting and drying, hut to a different. extent. The fixation in montmorrilonites is the most enhanced by wetting and drying.

However, not all illiteg exhibit the phenomenon of K-fixation to the same extent. According to Dr H.W.V.d.MAREL ") some illites do not fix at all, while other illites may fix as much as 35 milli-equivalents $K$ per 100 gram of clay (fraction $<2 \mu$ ). Both the vermiculites and montmorillonites are variable as to their ability to fix $\mathbb{K}$, but. do not vary as much as the illites.

From a number of fixating and non-fixating river-clay soils and sea-clay solls of the. Netherlands the clay separate (fraction smaller.than $2 \mu$ ) was analysed. The DTA curves of these clays are reproduced in fig. 21 .

- The clay from Winsum does not fix $K$ in any appreceable amounts, whereas the clays from Hedel, Veldriel and Etten do (HAUSER, .124). According to DTA and $X$-ray analysis ${ }^{*}$ ) the principal clay mineral in these clays is illite. The differences in the DTA curves of the clays lies in the first endothermic reaction. The non-fixating Winsum clay exhibit only a small reaction at about $150^{\circ} \mathrm{C}$. The strongly fixating clays Hedel and Etten exhibit the flrst reaction much stronger, whereas the curve of the moderate fixating Veldriel lies inbetween.

*) personal communication.

* The results of which were kindly reported by Dr H.W.v.d.MAREI 


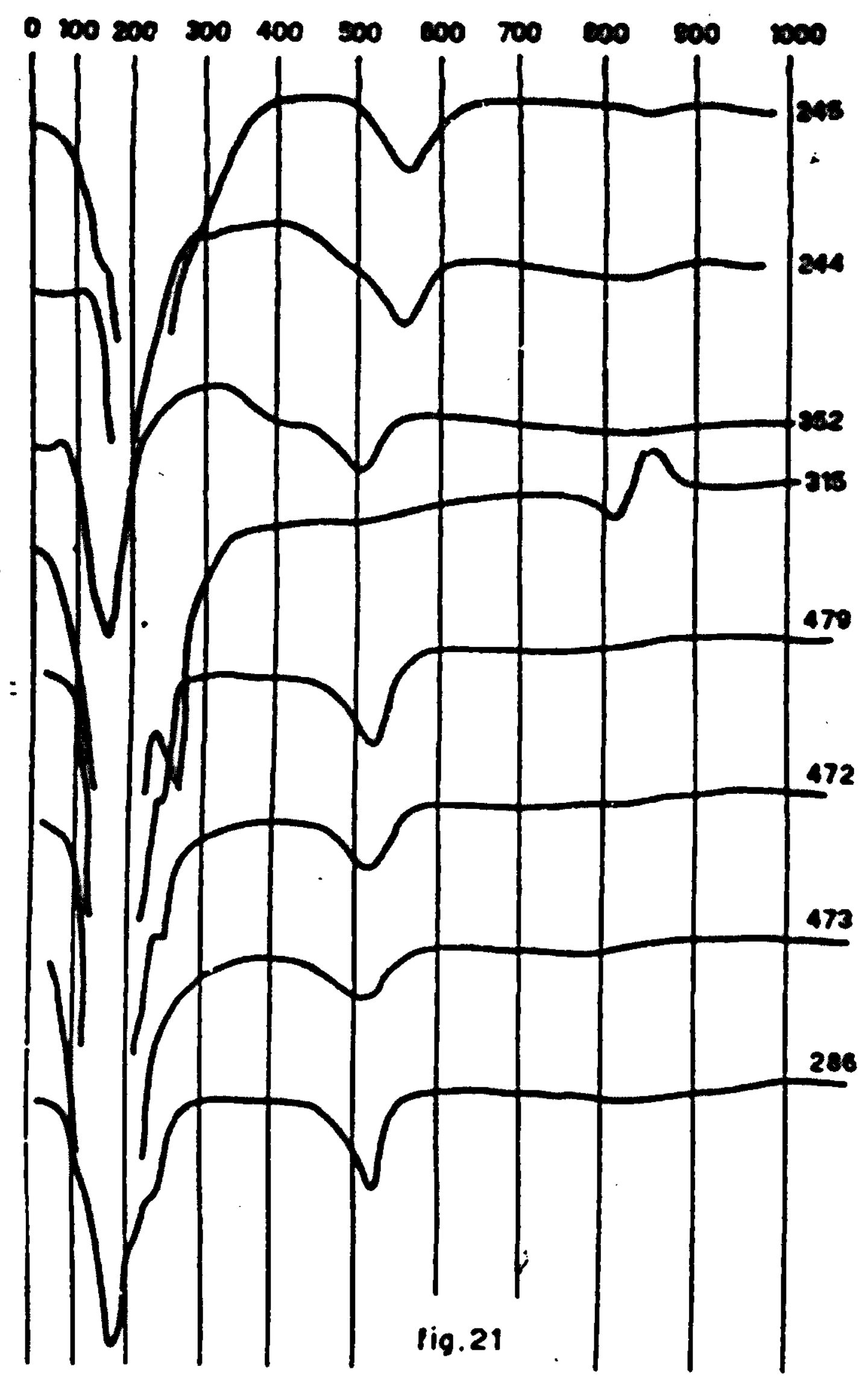

DTA curves of some K-fixating clays and clay minerals. 245: Zoeterwoude. 244: Hoge Waard. 352: Kleveneerd. 315: Vermiculite, S.Africa. 479: Etten. 472: Hedel. 473: Veldriel. 286: Illite, Flthian Illinois.

The explanation of an emerged first endothermic reaction in the fixating illites might be found in the lattice constitution of these clay minerals. The crystal structure of the nonfixating illites (which is considered to be almost identical with the structure of muscovite) may be represented by.

$$
\cdots \mathrm{SI}_{2} \mathrm{O}_{5} \quad \therefore \mathrm{Al}(\mathrm{OH})_{2} \quad \text {. } \mathrm{SI}(\mathrm{Al}) \mathrm{O}_{5} \mathrm{~K} \cdots
$$

The great $\mathrm{K}$-ion is bound electrostaticaliy between subse- 
quent lattice layers. In the case of fixating illites the $\mathrm{K}$ is partially absent in the lattice and is isomorphously replaced by anj other ion which fixes inbetween the lattice-layers. The most commonly occurring replacement in nature is that by $\mathrm{H}_{3} \mathrm{O}^{+}$ Ions, as was indicated already by TAMM (see HAUSER 124). Additional evidence of the replacement of $\mathrm{K}^{+}$by $\mathrm{H}_{3} \mathrm{O}^{+}$ions in fixating illites 18 1. the greater water content of fixating illites and 2. the more acid reaction of fixating illites, as compared with non-fixating illites.

As the $\mathrm{H}_{3} \mathrm{O}^{+}$lons $1008 \mathrm{e}$ water upon heating, at a temperature between 100 and $200^{\circ} \mathrm{C}$ and the lattice-K do not, it is clear that the first endothermic reaction in the fixating illites is of more pronounced character than in the non-fixating illites. Probably the magnitude of the first endothermic peak is a function of the fixation capacity, but at this time no attempt has been made to prove this statement. The phenomenon of an enhanced first endothermic reaction, however, is obvious for the fixating ilites.

$A$ second point of interest with relation to the $K$-fixation of clay solls is demonstrated in the curves of Zoeterwoude and Hoge Taard ( $f i \bar{g} .21$ ). These clays are deposits of the Oude Rijn, an old branch in the delta of the Rhine, and were laid down in Roman times or pre-Roman times. Both clays exhibit rather strong K-fization. From the DTA curves the clay separates appear to be mixtures of illite and vermiculite. Probably both constituents in these clays are responsible for the fixation.

The presence of vermiculite in clay separates of soils was first found by TALKER (278) in East Ledekin soil and some other Scottish so1ls, and subsequently by BUEHRER (39) and COLEMAN (57).

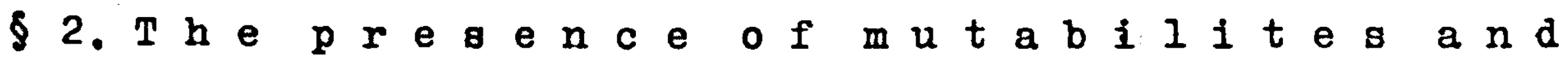

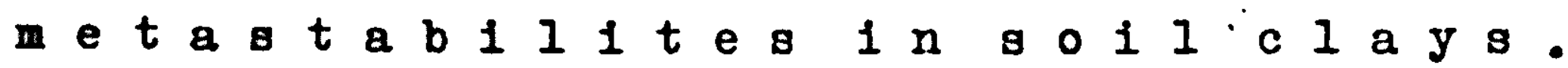

In chapter III attention was drawn to the influence of the degree of cryatalization upon the thermal reaction temperatures of clays. The presence of clay minerals with different degree of crystallization was first indicated by SEDLETSKII (265). The better the degree of cryatallization $i \dot{s}$, the higher are the reaction temperatures and the more accentuated appear the reactions.

With this statement at hand, the good and poorly crystal- 
Ilzed minerals may be ùistinguished in soll clay. The dcgree of crystallization of clay, which depends upon environmental conditions (temperature, concentration of the soll solution), probably is not static, but dynamio (JACOB, 155). Under proper conditions the poorly crystallized bodies may convert to better crystallized minerals. Or the good crystallized products may be first dissolved and gfterwards precipitated and recrystallized to mutabilites. In relatively high concentrated soll solutions imperfectly crystallized clay minerals may arise, as ras pointed out by EDELMAN and SCHUFFELEN (75) and SCHUYLENBORGH (256).

The poorly crystallized clay mineralo of the kaolinitegroup (the so called fireclay minerals) are distinguished by a relative great amount of adsorbed water, evading from about 100 $-200^{\circ} \mathrm{C}$ (see fig. 22, curve 253, 228 and 223). The water of constitution evades around $550^{\circ} \mathrm{C}$, that is at a lower temperature than the well crystallized kaolinites do loose their water. All reactions in the poorly crystallized bodies are relatively faint.

The kaolinite, present in the mottled clay of a laterite profile from Banka (curve 192, $11 g$. 22) appears to be of the poorly crystallized type. This probably accounts for the waterlogging of the mottled clay layer in laterites. Laterites without mottled clay (Ranau, Temangal) only contain well cryatallized kaolinites as sillcate clay mineral. The well crystallized types hold no adsorbed water; whereas the poorly crystallized types hold adsorbed water in rather great quantities.

Though both clays consist of kaolinites, the physical behaviour of the two soil types is different, on account of the degree of crystalization of the clay mineral.

The curves of well and poorly crystallized hydrous iron oxydes have been given in $11 \mathrm{~g} .14^{\mathrm{a}}$ chapter III.

Though no factual data are at hand of mutabilites in the illite- and montmorilionite-groups of clay minerals, it is to be expected that with these clays anelogous differences occur. Probably any illite is the poorly crystallized form of muscovite in soil clays. The presence of muscovite in the clay fraction of soils was found by FAVEJEE $(83,85)$. 


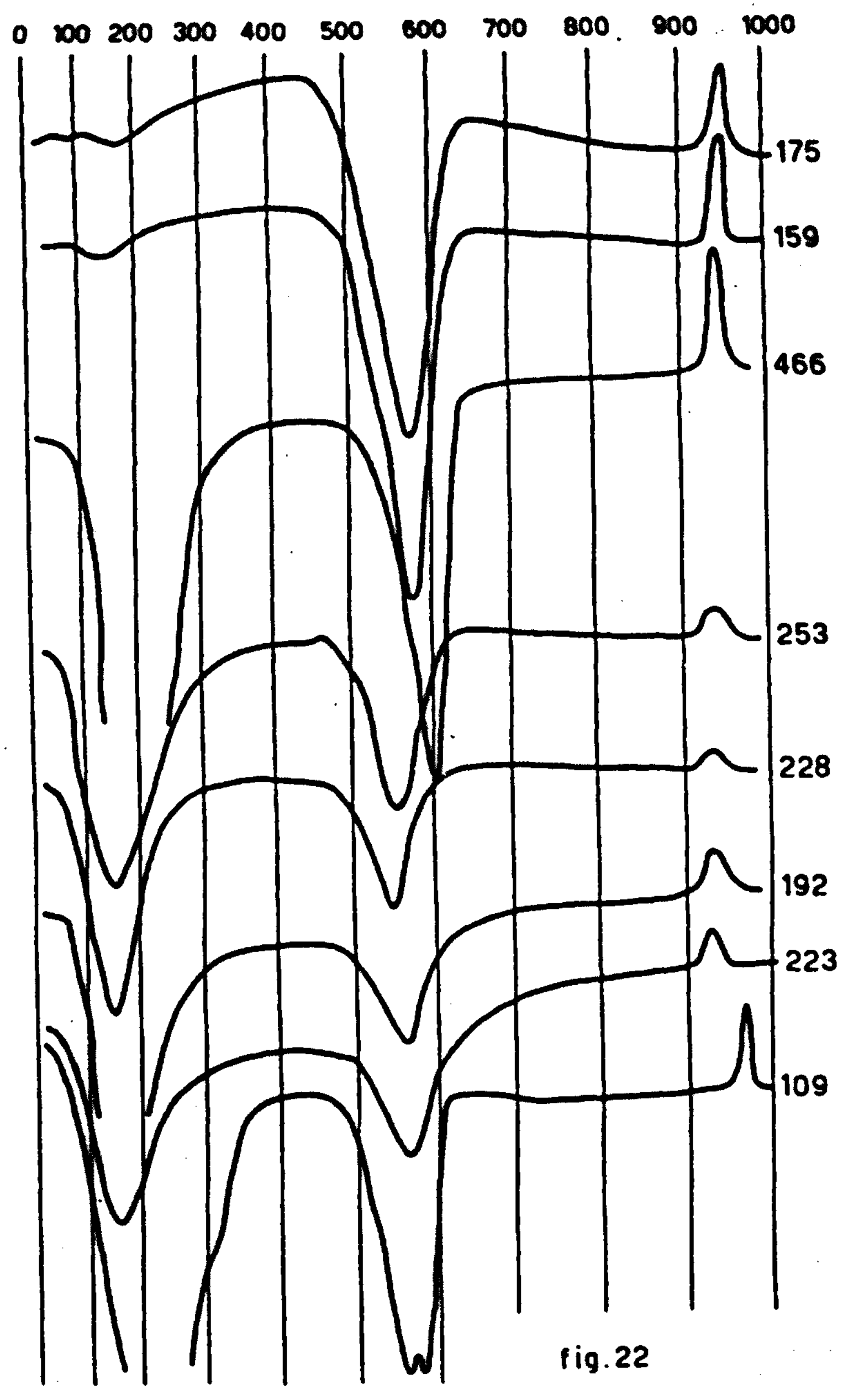

DTA curves of some kaolinitic clays and clay minerels. 175: kaolinite Drybranch, Georgia. 159: porcelain earth, Banka, Indonesia. 466: Halloysite, Mindesberg, Germany. 253: bonding clay, Holzhausen, Germany. 228: kaolinite, Meissen, Saxony. 192: mottled clay from laterite profile, Banka. 223: English Ptre-clay. 109: Djebel Debar, N.Africa.

§3. MIs c e I I a n e o us results.

In fig. 23 a number of curves is represented, related to various tropical and Dutch soils. The Maratakka clay soil of Surinam (curve 310) is a river clay. The clay mineral in this soil appears to be of the 1lite group, but with some peculia- 
rities. The lattice water evades at about $450^{\circ} \mathrm{C}$, being extremely low for illites. According to $X$-ray records ${ }^{*}$ the basal. spacing of this clay mineral is $7 \&$; which is likewise extremely low for illite, and which would rather be an indication of kaolinite. However, the other characteristic kaolinite deflections are absent. Only characteristic illite deflections (except the $7 \&$ value) are present. Probably it is a new type of clay mineral.

Some other river clay solls of Surinam (curve 285), exhibit the presence of normal illite as a clay mineral in these soils.

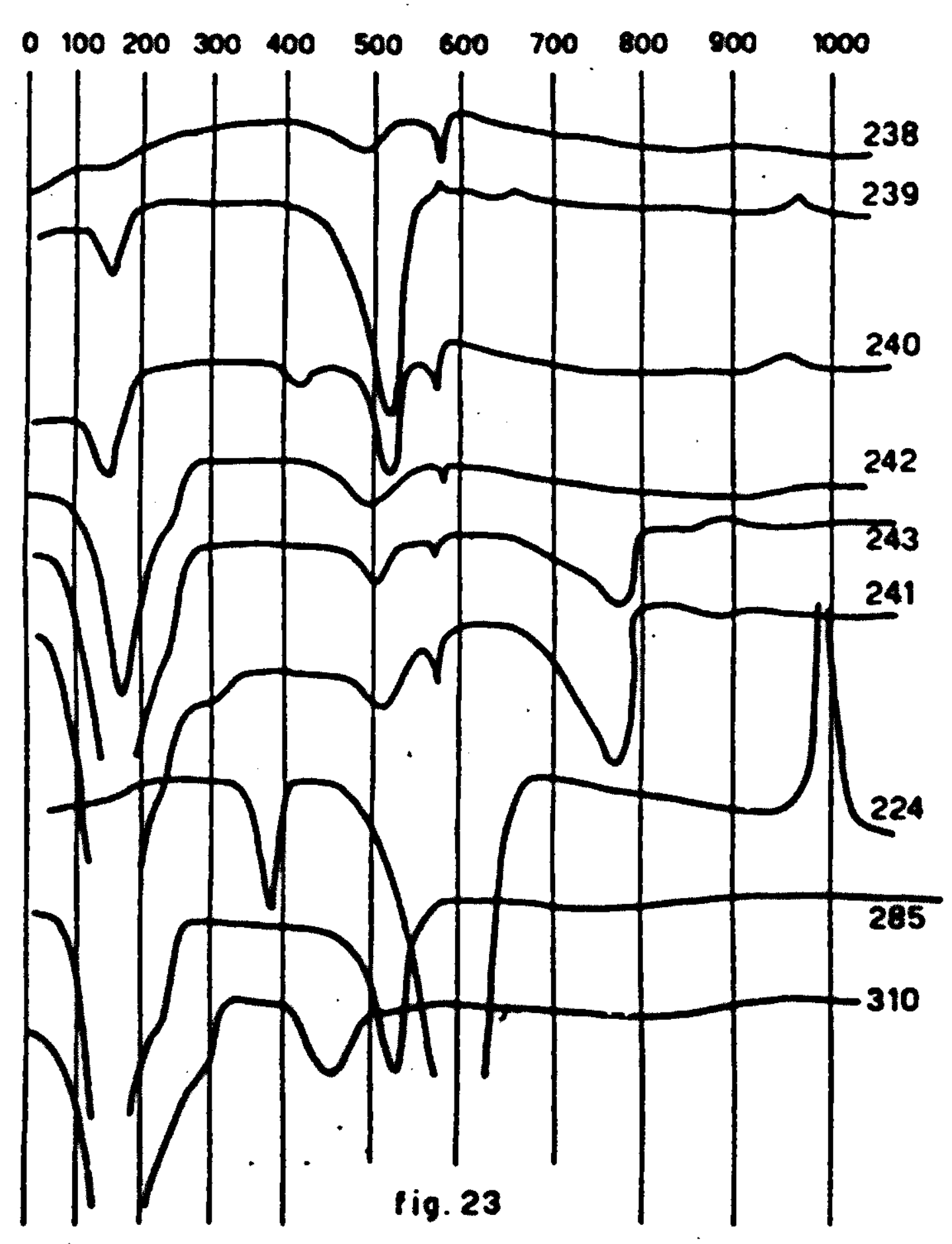

DTA curres of some New Guinea clay soils and of some clay soils from Surinam. 238: Meraukee district. 239: N.Guinea 12. 240: N. Guinea 14. 242: N.Guinea 7.241 and 243 8011s from calcareous parent material. 224: bauxite, Surinom. 285 and 310 Maratakka clay soils (river clays).

*) personal communication of Dr H.W.van der Marel. 
The carves of same New-Guinea soils (No. 238 and 240) show the presence of quartz in great quantities in the clay fraction. In one soll from Sumatra van der MAREI (199) reported likewise the presence of quartz in appreciable quantities in the clay fraction. Purther examples of ouch scils appear to be some of these New-Guinea s011s. Such s011s, rich in quartz in the clay fraction exhibit extremely bad agricultural characteristics, as bad workability, extremely low water holding capacity and the absence of a sufficlent exchange complex.

Some other New-Guinea soils (curves 239, and 242) consist of mixtures of kaolinites and illites or of pure kaolinite. The solls, derived from calcareous parent material contain montmorilionite (curves 241, 243).

Finally a number of curves is reproduced from Dutch soils. Illite appears the most common clay mineral in Dutch soils, as was already found by FDFLMAN and FAVEJEE (73), FAVEJEE (81) and van der MAREI (200). The presence of beidellite in clays from calcareous parent material (South Ifmburg) is indicated in curve 352 (118. 21).

84. Re act 1 o $n$ r a n e s a $n$ d $r$ e a $t i o n$ i $n-$

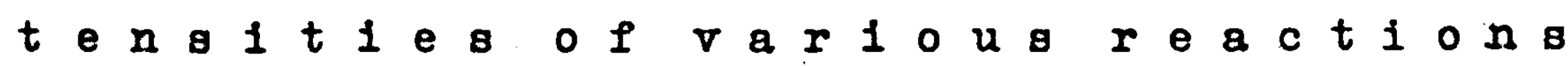

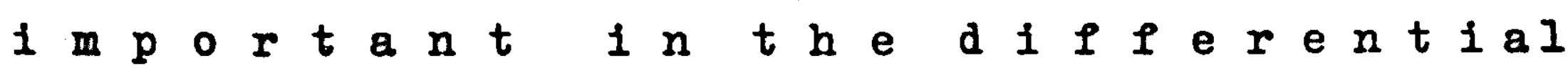
$t h e r m a l$ a n a I y g 1 a 01 c 1 a $y$ s.

In fig. 24 "assymptotic" DTA curves are shown for some of the more important clay minerals. The horizontal axis represents the temperature axis, while the on vertical axis the heat of reaction per one gram of clay is plotted.

Such assymptotic DTA curves may arise-theoretically when the conditions are satisfied. for the attainment of $T$, such as were indicated in chapter IV $\S 2$.

From the data which were laid down in table 11 and from the equation 36 in chapter $V$ the actual recorded reaction temperatures may be compared with the assymptotic reaction temperaturea.

As was seen, in chapter IV, $\$ 4$; the peak area is a function of the heat of reaction. It may now be understood, why kaolinites and the hydrous oxydes give rise to well developped peaks, while the 1 liftes and montmorillonites exhibit less well developped peaks. 


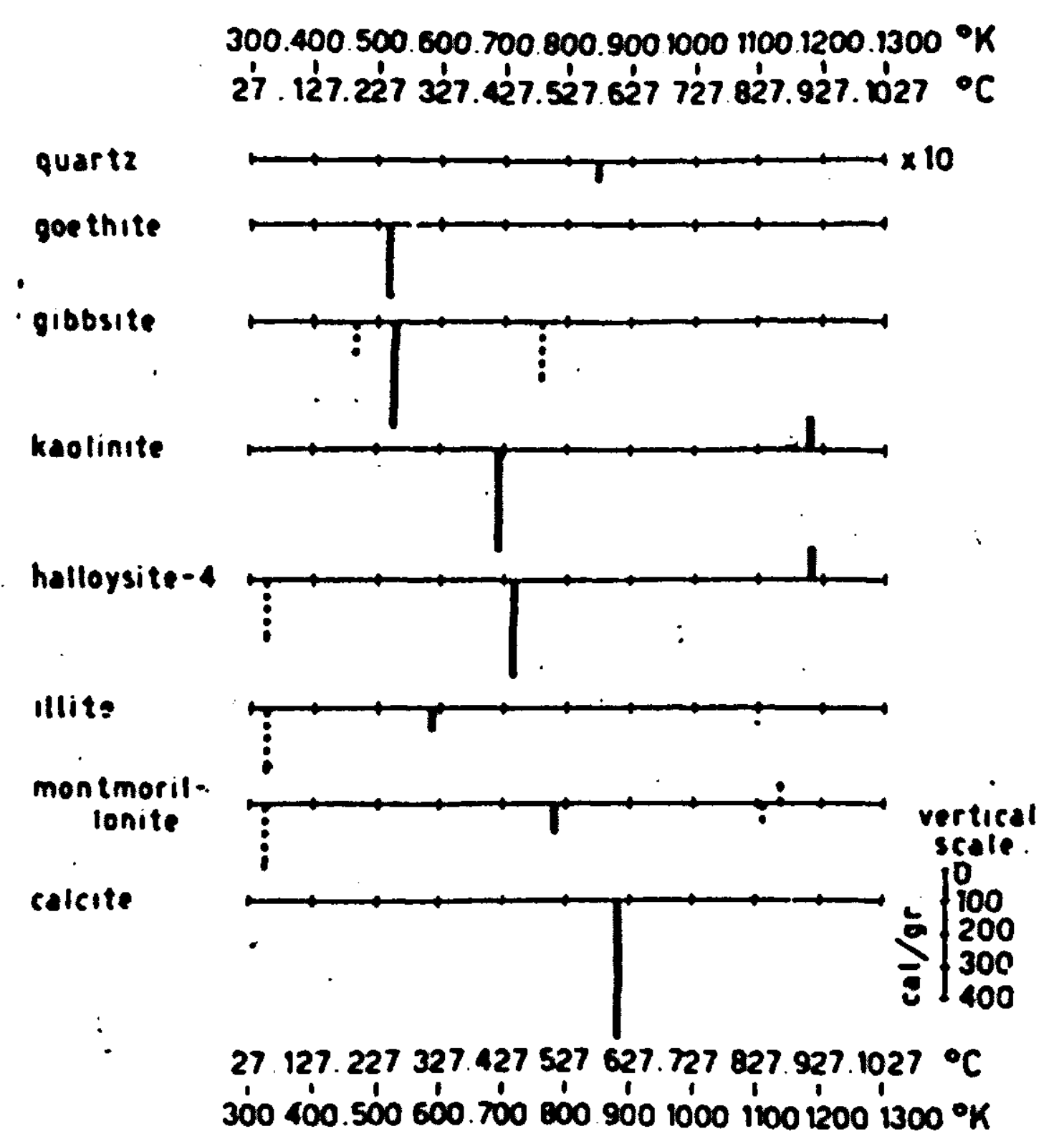

Fig. 24 Assymptotic DTA curves of some clay minerals. The vertical axis represent the heat of reaction in cal/gr. For quartz the vertical scale is magnified 10 times. 


\section{SAMENVATTING}

Als klei verhit wordt tot hoge temperaturen $\left(1000^{\circ} \mathrm{C}\right)^{-}$vinden een aantal reacties plaats. De voomaamste hiervan zijn:

1. Verlies van geadsorbeerd water (endotherme reactie);

2. verlies van constitutie water (endotherme reactie);

3. Verlies van koolzuur uit carbonaten (endotherme reactie);

4. oxydatie van oxyd eerbare bestanddelen (exotherme reactie);

5. rekristallisaties (endo- of exotherme reactie).

$B 1 j$ de differentiéle thermische analyse (DTA) worden de warmte-effecten gepard aan deze reacties gemeten met behulp van een differentieel thermo-element. Een loot hiervan bevindt zich in de kleisubstantie, de andere loot in een thermisch inerte stof, b.v. gegloeid $\mathrm{Al}_{2} \mathrm{O}_{3}$. Klel en inerte stof bevinden zich in eenzelfde monsterblok in een oven. Treedt er geen reactie op in de kle1, dan is de temperatuur van klei en inerte otof vrijwel gelijk, zodat het differentiële thermo-element geen e.m.k. bezit. Treedt tijdens de verhitting een endotherme reactie op in de klei, dan uit zich dit in een achterblijven in temperatuur van de kle1 bij vergelijking met de inerte stof; het differentiele thermo-koppel bezit een e.m.k. Tijdens een exotherme reactie in de klel is de e.m.k. van het differentiële thermo-koppel tegengesteld aan die tijdens een endotherme reactie.

Door nu zowel de overtemperatuur als het temperatuurverschil tussen kleimonster en het inerte materiaal synchroom te registreren ontstaat een DTA curve (zie fig. 9) die voor analyse doeleinden geschikt is.

De ontledingstemperaturen van de verschillende kleimineralen zijn specifiek, zodat hiermee een identificatie mogelijk is.

In principe is DTA de oudste methode voor kleionderzoek in het lahoratorium. Zij werd het eerst toegepast door IE CHATELIER. Er begtaat echter een groot aantal tegenstrijdige oprattingen omtrent de interpretatie van de gevonden regultaten.

De voornaamste tegen de methode geopperde bezwaren zijn: 1. het subjectieve karakter van de methode. De resultaten, ver kregen met eenzelfde klel, maar onderzocht in verschillende laboratoria, zifn niet identiek. De piektemperaturen kunnen onderling verschillen met een bedrag van $150^{\circ}$;

2. het ontbreken van een theoretische basis, zodat een vergelijking met andere methoden, zoals gewichts analytische dehydratie en thermische dilatometrie, zeer bezwariljk 18. 
Het doel van deze studie is de analyge van het samenstel van factoren, dat de DTA resultaten modificeert.

Na een beschrijving van de gebruikte apparatuur in hoofdstuk II wordt in hoofdstuk III een aantal waarnemingen weergegeven over de factoren die het verloop van de curven bepalen.

Deze factoren kunnen als volgt samgevat worden:

A. factoren gebonden aan de apparatuur:

1. oploopsnelheid van de oventemperatuur;

2. de aard van het gebruikte monsterblok;

3. diepte en straal van de monstergaten in het blok;

4. de plaats van temperatuurmeting van oventemperatuur en differentiële temperatuur;

5. de aard en afmetingen van de thermo-koppels;

6. de ard van de inerte stof;

7. de pakking van de klel en van de inerte stof in de monstergaten;

8. de bedekking van de monstergaten tijdens de analyse;

9. de samenstelling van de damp in de ovenatmosfeer;

B. factoren gebonden aan de kle1:

10. de deeltjesgrootte en de aard van de anwezige kle1mineralen;

11. de kristallisatiegraad van de klei;

12. de geadsorbeerde kationen;

13. de aanwezigheid van verontreinigingen in de kle1.

Het registratie mechanisme als variabele factor is buiten beschouwing gelaten. Het spreekt vanzelf dat versterking of verzwakking van de thermostromen van het differentieel thermoelement leidt tot een meer of minder geprononceerde curve.

Het blijkt, dat de factoren $1,3,6,8,9,10$ en 11 de piekvergchuiving bepalen, terwijl de factoren $1,2,4,7,8$, 10 - 13 de algemene vorm van de curve bepalen (zie fig. 10 - 12, 14 - 17 en 19). In de tabelien 2,3 en 5 zijn een aantal quantitatieve gegevens over piekverschuiving, piekhoogte en piekoppervlak vermeld.

Het blifkt dat er vooral twee opreaken zijn.aan te wijzen voor het optreden van de piekverschuivingen, n.i.:

1. Reacties die gepard gaan met gewichtoveranderingen remmen zichzelf bif een niet-stationnair reactieverloop, doordat + de ontledingsproducten nlet ogenblikkelijk afgevoerd wor den.

2. Zuiver theralsche oorzaken, die bepaald worden door het feit, dat zich op leder moment van temperatuurmeting geen 
thermisch evenwicht heeft ingestëld in klel en inerte mas8a. .

In hoofdstuk IV. wordt de formulering van beide effecten gegeven; het blijkt dat de plekverschuiving ( $T_{\text {obs }}-T$ ) els volgt met de experimentele condities samenhangt:

$$
\mathrm{T}_{\mathrm{obs}}-\mathrm{T}=\frac{\mathrm{r}^{2}}{4} \dot{C}(1 / \mathrm{fa}-1 / \mathrm{fa})+\frac{\mathrm{Q} \cdot \log \mathrm{p}}{4.571 \mathrm{~b}(\mathrm{~b}-\log \mathrm{p})}
$$

De invloed van de warmte-overdrachtscoefficient en van het. warmte-gelëidingovermogen van het gebruikte monsterblok is niet in de formulering opgenomen; het effect hiervan op de piekverschuiving is gering, op het plekoppervlak echter groot.

In hoofdstuk $V$ wordt boveristaande formule toegepast op een aantal waarnemingsresultaten, waruit de practiache bruikbaarheid blifkt. De omrekening van.reactie-temperaturen, bepaald met behulp van verschillende apparaten, wordt hierdoor mogelijk.

De toepassing van DTA op enkele speciale problemen uit de bodemkunde wordt gegeven in hoofdstuk VI. Het blijkt dat K-fixerende en niet $\mathrm{K}$-fixerende 1 llieten verschillend reageren ( $f i g$. 21): Ook tussen de curven van goed gekristalliseerde kaolinieten en elecht gekristalliseerde kaolinieten bestaan verschillen (1ig. 22). De kaoliniet uit de mottled clay laag van laterieten blijkt van het slecht gekristalliseerde type te zijn (z.t.in. fireclay mineraal). In fig. 21 - 23 worden van een aantal gronden uit Nieuw-Guinea, Suriname en Nederland DTA curven gereproduceerd. Enkele N.-Guinese gronden blijken grote hoeveelheden kwarts te bevatten in de kleifractie. De alluviale kleigronden van Suriname bevatten veel illiet; een afwijkend type llliet werd gevonden. De Nederlandse alluviale kleigronden bevatten voornamelijk 1lliet, wat reeds bekend was uit vroegere onderzoekingen van EDELMAN, VAN BAREN en FAVEJEE. De aanwezigheid van beidelliet in Kleveneerd ( $\mathrm{Z}$.Iimburg) is waarschijnlijk. Aan het eind van hoofdstuk VI worden voor enige kleimineralen de assymptotische reactie-temperaturen en de te verwachten reactie-intensiteiten vermeld voor DTA curven. Fig. 24 is getekend naar analogie met de $n$ X-ray data card" voor röntgenanalytisch kleiondersoek. Het gegeven schema is een eerste poging tot een objectieve weergave van de met de DTA gevonden resultaten.

*). Voor de beteken1s van de gebruikte symbolen zie men hoofdstuk IV. 


\section{APPENDIX I:}

$$
\begin{aligned}
& \text { Solution of the difierential equation } \\
& \frac{d T}{d t}=a\left(\frac{d^{2} T}{d r^{2}}+\frac{1}{r} \frac{d T}{d r}\right) \text { ar applied to DTA. }
\end{aligned}
$$

The problem is the solution of

$$
\frac{d T}{d t}=a\left(\frac{d^{2} T}{d r^{2}}+\frac{1}{r} \frac{d T}{d r}\right)
$$

$I=T$ as a function of $\underline{t}$ and $\underline{r}$ may be represented by the series

$$
T_{t, r}=\psi_{0}(t)+\psi_{1}(t) \frac{r}{n !}+\psi_{2}(t) \frac{r^{2}}{2 !}+\ldots+\psi_{n}(t) \frac{r^{n}}{n !}+\psi_{n+1}(t) \frac{r^{n+1}}{n+1 !}+\ldots
$$

where the $\psi(t)$ represent functions of $t$.

Fartial differentiation of $T$ with respect to $t$ in (2) gives:

$\frac{\partial T}{\partial t}=\psi_{0}+\psi_{i} \frac{r}{\pi !}+\psi_{2} \frac{r^{2}}{2 !}+\ldots+\psi_{n}^{\prime} \frac{r^{n}}{n !}+\psi_{n+1}^{\prime} \frac{r^{n+1}}{(n+1) !}+\ldots$.

Partial differentiation of $T$ with respect to $r$ in (2) Bives:

$\frac{\partial T}{\partial r}=\psi_{1}+\psi_{2} \frac{r}{T !}+\psi_{3} \frac{r^{2}}{2 !}+\ldots+\psi_{n+1} \frac{r^{n}}{n !}+\psi_{n+2} \frac{r^{n+1}}{(r+1) T}+\ldots$

while double ifferentiation of $T$ with respect to $r$ gives:

$\frac{\partial^{2} T}{\partial r^{2}}=\Psi_{2}+\psi_{3} \frac{r}{T !}+\psi_{4} \frac{r^{2}}{2 !}+\ldots+\psi_{n+2} \frac{r^{n}}{n !}+\psi_{n+3} \frac{r^{n+1}}{(n+T) !}+\ldots$

In order to get the solution of equation (1) we must find the values of the $\psi^{\prime} s$ and $\psi^{\prime \prime}$ 's in the equations (3), (4) and (5). If equation (3) is to be equal to a times the sum of equation (5) plus $\frac{1}{r}$ times equation (4), the following relation must hold between the coefficients

$\Psi_{n}^{\prime}=a\left(\Psi_{n+2}+\Psi_{n+2} \frac{1}{n+1}\right)=a \cdot \Psi_{n+2}\left(1+\frac{1}{n+1}\right)=a \cdot \Psi_{n+2} \frac{n+2}{n+1}$

Conversion of (6) gives

$$
\psi_{n+2}=\frac{\psi_{1} n}{a} \cdot \frac{n+1}{n+2}
$$

With the aid of equation ( 7 ) we now are able to express the coefficients $\psi_{0}, \psi_{1}, \psi_{2}, \psi_{3}, \ldots \psi_{n} \ldots \Psi_{n+m} \ldots$ in the derivatives $\psi_{0}^{\prime}$ and $\psi_{j} ; \psi_{0}^{\prime \prime}$ and $\psi_{1}^{\prime} ; \ldots$ etc.

So for: $n=0 \quad \Psi_{2}=\frac{\Psi^{\prime}}{a} \cdot \frac{1}{2}$

$$
\begin{array}{ll}
\mathbf{n}=2 & \Psi_{4}=\frac{\psi_{2}}{\mathrm{a}} \cdot \frac{3}{4}=\frac{\psi_{0}^{\prime \prime}}{a^{2}} \cdot \frac{1.3}{2.4} \\
\mathbf{n}=1 & \Psi_{3}=\frac{\Psi_{1}^{\prime}}{\mathrm{a}} \cdot \frac{2}{3} \\
\mathbf{n}=3 & \Psi_{5}=\frac{\Psi_{3}^{\prime}}{\mathrm{a}} \cdot \frac{4}{5}=\frac{\psi_{1}^{\prime \prime}}{\mathrm{a}^{2}} \cdot \frac{2.4}{3.5}
\end{array}
$$


Substitution of the coeffieients $\Psi$ in equation (2) leads to

$$
\begin{aligned}
r_{t, r} & =\psi_{0}+\frac{1}{a} \cdot \frac{1}{2} \psi_{0}^{\prime} \frac{r^{2}}{2 !}+\frac{1}{a^{2}} \cdot \frac{1.3}{2.4} \psi_{0}^{n} \frac{r^{4}}{4 !}+\ldots \\
& +\psi_{1} \frac{r}{1 !}+\frac{1}{a} \cdot \frac{2}{3} \psi_{1}^{\prime} \frac{r^{3}}{3 !}+\frac{1}{a^{2}} \cdot \frac{2.4}{3.5} \psi_{1}^{n} \frac{r^{5}}{5 !}+\ldots
\end{aligned}
$$

In equation ( 8 ) the coefficients $\psi_{0}$ and $\psi_{1}$ are functions of $t$ and are given by the conditions of tue experiment. In order to determine the $\psi^{\prime}, 8$, it is first noted that in well carried out DTA experiments the following conditions should be satisfied.

1. There should be a constant heating rate of the inert material in the sample holder. The condition can be formulated as

$$
\left(\frac{d T}{d t}\right)_{r=0}=C
$$

The integrated form of equation (9) is

$$
T_{t, r=0}=C t+T_{0}
$$

where $\mathbb{T}_{0}$ represents the initial (absolute) temperature of the experiment and $C$ the heating rate. To a very close approximation holds as well

$$
\mathrm{T}_{t, r=\mathrm{R}}=\mathrm{C} \cdot \mathrm{t}+\mathrm{T}_{\mathrm{O}}
$$

The left hand side of equation (10) represents the temperature. of the sample holder as a function of time.

2. 471 temperatures should be measured on the axis of the cylindrical holes. That is to say, letting Tobs $_{\text {operent }}$ the observed temperature

$$
\mathrm{T}_{\text {obs }}=\mathrm{T}_{\mathrm{r}=0} \text { for all values of } \underline{t} \text { and } \underline{\mathrm{C}} \text {; }
$$

3. The heat is supplied to the samples in the cylindrical holes from all sides. Then the radial temperature gradient in the centre of the holes equals zero for all values of $t$ and $\underline{\text { C. Thus }}$

$$
\left(\frac{\partial T}{\partial r}\right)_{r=0}=0
$$

With the aid of these conditiops the coefficients $\Psi_{0}$ and $\Psi_{1}$ may be expressed as functions of $t$, as follows from equations (9) and (10)

$$
\begin{array}{ll}
\Psi_{0}=c t+T_{0} & \text { for } r=R(\text { and for } r=0)+) \\
\Psi_{0}^{r}=c & \text { for } r=R(\text { and for } r=0) \\
\Psi_{0}^{\prime \prime}=0 & \text { for } r=R(\text { and for } r=0) \\
\Psi_{0}^{\prime \prime \prime}=0 \ldots \text { etc. } & \text { for } r=R(\text { and for } a=0)
\end{array}
$$

+ ) only when $t \gg \frac{r^{2}}{4 a}$, see below. 
and from (11)

$$
\begin{array}{ll}
\psi_{1}=0 & \text { for } r=0 \\
\psi_{1}^{\prime}=0 & \text { for } r=0
\end{array}
$$

Substitution of the equations (12) and (13) in equation (8) gives

$$
\begin{aligned}
& T_{t, r}=c t+T_{0}+\frac{1}{a} \cdot \frac{1}{2} c \frac{r^{2}}{2 !}+0+0 \ldots \\
& T_{t, r}-T_{0}+c t+\frac{r^{2}}{4 a} c
\end{aligned}
$$

Substitution of equation (9) in (14) leads to

$$
T_{t, r}-T_{0}=t\left(\frac{d r}{d t}\right)_{r=0}+\frac{r^{2}}{4 a}\left(\frac{d r}{d t}\right)_{r=0}
$$

The term $\frac{r^{2}}{4 a}\left(\frac{d T}{d t}\right)_{r=0}$ describes the temperature courae within the sample. but only if $t$ is large enough with respect to $\frac{r^{2}}{4 a}$. For $t \gg \frac{r^{2}}{4 a}$ holds

$$
\left(\frac{d T}{d t}\right)_{r=R}=\left(\frac{d T}{d t}\right)_{r=0} \text {, or } C^{\prime}=C \text {. }
$$

Under this condition the temperature difference between the fringe of the sample hole and the centre of the cylindrical sample equals

$$
T_{r=R}-T_{r=0}=\frac{R^{2}}{4 a}\left(\frac{d T}{d t}\right)_{r=0}
$$

The question remains as to what is to be understood by the condition $t>r^{2} / 4 a$, because this condition determines the applicability of equations (15) and (16). As an aid in anowering this question Drs D.A. de VRIES, of the Physical Laboratory, Wageningen kindiy drew the writer's attention to the numerical tables in JAKOB's book (157). The table for values of $\theta / \theta_{\mathrm{B}}$ as a function of time and position of temperature measurement, for the heating of cylinders with $h \gg R$ is represented here.

\section{Table 15}

Values of $\theta / \theta_{R}$ for the heating of cylinders (with $h \gg R$ ) as a function of position of measurement of temperature (represented as $r / R$ ) for several values of $t a / \mathrm{R}^{2}$.

\begin{tabular}{l|llll} 
& \multicolumn{5}{c}{$\frac{t . \mathrm{a}}{\mathrm{B}^{2}}$} \\
$\mathrm{r} / \mathrm{R}$ & 0.08 & 0.16 & 0.32 & 0.80 \\
\hline 0 & 0.016 & 0.123 & 0.354 & 0.691 \\
0.8 & 0.054 & 0.191 & 0.420 & 0.725 \\
0.5 & 0.122 & 0.287 & 0.505 & 0.768 \\
0.8 & 0.268 & 0.443 & 0.628 & 0.828 \\
0.8 & 0.470 & 0.621 & 0.755 & 0.888 \\
1 & 1 & 1 & 1 & 1 \\
\hline
\end{tabular}


To teet the validity of equations (15) and (16); values of $\frac{\theta_{\mathrm{R}}-\theta_{\mathrm{r}}}{\theta_{\mathrm{R}}}$ have been computed from table 15 and have been-calculated according to equation (16). The results are presented in table 16 . for comparison.

\section{Table 16}

Values of $\frac{\theta_{R}-\theta_{I}}{\theta_{R}}$, computed from table and calculated from equation (16), for eeveral values of $r / R$ and $\frac{t . a}{R^{2}}$.

$$
\frac{\theta_{\mathbf{R}}-\theta_{\mathbf{r}}}{\theta_{\mathbf{R}}}
$$

\begin{tabular}{|l|ll|ll|ll|}
$r / R$ & $\frac{t . a}{R^{2}}=0.08$ & $\frac{t . a}{R^{2}}=0.32$ & $\frac{t . a}{R^{2}}=0.80$ \\
\hline 0 & 0 & 0 & 0 & 0 & 0 & 0 \\
0.7 & 0.038 & 0.109 & 0.066 & 0.072 & 0.034 & 0.034 \\
0.5 & 0.106 & 0.246 & 0.151 & 0.161 & 0.077 & 0.077 \\
0.6 & 0.252 & 0.436 & 0.274 & 0.285 & 0.137 & 0.137 \\
0.8 & 0.454 & 0.630 & 0.401 & 0.413 & 0.197 & 0.197 \\
1 & 0.984 & 0.984 & 0.646 & 0.646 & 0.309 & 0.309 \\
\hline
\end{tabular}

It appears from the data in table 16 that only for values $\frac{t . a}{2}>0.32$ the calculation of temperature differences within the fylindrical samples with the aid of equation (16) is justified. Taking the condition as

$$
\frac{t . a}{R^{2}} \geqslant 0.5
$$

equations (15) and (16) are valid for all values of

$$
t \geqslant 2 \cdot \frac{R^{2}}{4 a}
$$

Normally condition (17) is fully obeyed in DTA experiments; so equation (16) is ralid. 
In view of the bad comparability of DTA curves, resulting from different equipmentis, the Britioh clay group (MACKENZIE, 191) made some efforts to arrive at a standarisation of equipments.

-In chapter III of this study the most important 1tems involved in an eventual standarisation are indicated. It was seen there that quite a number of. factors should be covered. In fact, any success of standarisation may be expected only if all equipments, including the recording mechanlom, are made as identical as possible. Any proposal to such rigourous reforms can be safely considered unprofitable.

Moreover, in the final section of chapter III was sugge日ted how the constants of the equipment should be chosen in order to get optimal information on any clay submitted to DTA. The identification of illites requires other experimental conditions than the identification of carbonates or of the iron mi.nerals. In view of the different requirements of the various minerals, standarisation probably will prove to be a serious disadvantage.

It was also shown in chapter IV and $V$ how the conversion of data obtained with different equipments may be carried out.

Thus, for qualitative purposes standardisation of equipment is impracticable, disadvantageous and unneccessary.

The only thing which is of interest is the firation of certain minimum requirements, to which all equipments should respond. The minimum requirements are the following.

1. A contimuous and synchronous recording of furnace temperature and difference temperature.

2. The maintenance of a heating rate as constant as possible during any experiment.

3. The measurement of the furnace temperature should be made in the clay sample itself.

The influence of most of the other factors involved and indicated in chapter III may be evaluated. with the aid of the formulae given in chapter IV and $V$.

For quantitative purposes there is no need for standardisation as long as the analysis remains empirically and the mi- 
nimum requirements, indicated above are fullfilled. What is of interest here is, however, the expression of the deviations of the differential temperature line in terms of calories. When this problem can be solved, a discussion about standardisation will be more fruitful. 


\section{LITERATURE CITED}

(1) AGAFONOFF, V.: Etude minéralogique du sol.

Trans. IIIrd Int. Congr. So1l Sc. 3:74-78.

(1935)

(2) AGAFONOFF, V. en G.JOURAVSKY: I'analyse thermique des sols

de Tunisie.

C.R.Acad.d.Sc1., 198: 1356-1358 (1934).

(3) AIEIXANDRE, .: Análisis térmico diferencial. de algunas arcillas y caolines espanolas.

Ann.Edafolog.y Fisol.veg. $\underline{8}$ :33-58 (1949).

(4) ALEIXANDRE, .: Differential thermal analysis of some Spanish clays and kaolins.

Trans.Fourth Int.Congr.Soil Sci., I:105-106 (1950).

(5) ALEIXANDRE,V and D.A.ESTRADA: Estudio fisico-quimico de varios talcos espanoles y de algunas masas ceramicas esteatiticas.

Anales d.I.R.Soc.Esp.d.Fis.y Quim.Ser.B, 45: 1075-1104 (1949).

(6) AIEXANDER,I.T.,G.T.FAUST,S.B.HENDRICKS,H.INSIEY and H.F. MCMURDIE: Relationship of the clay minerals halloysite and endelite.

Am. Mineral. 28:1-19(1943).

(7) ALEXANDER,I.T.,S.B.HENDRICKS and R.A.NELSON: Minerals present in soil colloids II: Estimation in some representative so1ls.

So11 Sci., 48:273-279 (1939).

(8) ALEXANDER,I.T.,S.B.HENDRICKS and G.T.FAUST: Occurrence of gibbsite in some soil-forming materials. Soll Sci.Soc. of Am.Proc., 6:52-57 (1941).

(9) AILAWAY,W.H.: Differential thermal analyses of clays treated with organic cations as an aid in the study of soil colloids.

Soil Sc.Soc. of Am.Proc. 13:183-188 (1948)

(10) ANTIPOV-KARATAEV, J.N. und B.K.BRUNOVSKY: Chemische und rontgenographische Untersuchungen kolloiden Fraktionen einiger Bodenarten.

Kolloid Zeitschrift 75:325-337 (1936). 
(11) ARENS,P.I.: Het drogen van kle1 (Iiteratuurstudie). Meded. No.10 Keram.Inst.Gouda, tevens Rapport T.A.259 Alg.Tech.Afd.T.N.0. 64 pp. (1949).

(12) ARENS,P.I.: Differential thermal analyois: a conventional method.

Trans.Fourth Int.Congr.So 11 Sc. III: 26-27 (1950)

(13) ATPERBERG,A.: Die Plastizität der Tone.

Int. M1tt. 1. Bodenk., 1:10-43 (1911).

(14) ATTERBERG,A.: Die Konsistenz und die Bindigkeit der Böden. Int. Mitt. 1. Bodenk., 2: 149-189 (1912).

(15) BARSHAD,I.: Vermiculite and its relation to blotite as revealed by base-exchange reactions, $\mathrm{X}$-ray analyoes, differential thermal curves and water content. Am. Mineral. 33: 655-678 (1948).

(16) BARSHAD,I.: The nature of lattice expansion and ita relation to hydration in montmorillonite and vermiculite.

Am. Mineral. 34:675-684 (1949).

(17) BARSHAD.I.: The effect of the interlajer cations on the expansion of the mica type of crystal lattice. Am. Mineral. 35:225-238 (1950).

(18) BATES,F. and F.P.PHEIPS: The new fixed point on the thermometric scale. Phys.Rev. 18:115-116 (1921).

(19) BATES,Th.F.,F.A.HILDEBRAND and A.SWINEFORD: Morphology and structure of endelite and halloysite. Am. Mineral: 35:463..484 (1950).

(20) BAVER,I.D.: Soll Phjsics, 2e ed. New-York, London 1948.

(21) BECK,C.T.: An amplifier for differential thermal analyais. Am. Mineral. 35: 508-524 (1950).

(22) BECK,C.W.: Differential thermal analysis curves of carbonate minerals.

Am. Mineral. 35:985-1013 (1950).

(23) BERGER,G.: De structuur van montmorilloniet (voorlopige mededeling over de methyleerbaarheld van klelen en kleimineralen).

Chem. Weekbl., Vol.38, No.4, 42-43 (1941). 


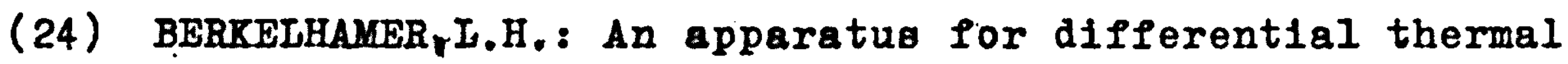
analyo18.

U.S.Bur. of Mines; Rept.Inv. No.3752,

17 pp. (1944).

(25) BERKELHAMER,I.H.: Differential thermal analysis of quartz. U.S.Bur. Mines Rept.Inv. No.3763, $18 \mathrm{pp}$. (1944).

(26) BERKEIHAMER,I.H. and S.SPEIL: Differential thermal analysis I and II.

Mine and Quarry Eng. 10:221-225; 273$279(1945)$.

(27) BOWER,C.A. and E.TRUOG: Base exchange capacity determination as influenced by nature of cation employed and formation of basic exchange salts.

So11 Sc1.Soc. of Amer.Proc., vol.5, 8689 (1940).

(28) BOYANOV,P.: Investigations on the colloldal fraction of Bulgarian so1ls I: Dehydration curves of mineral collolds of some Bulgarian so118.

Zemed .Nauka 1:55-72 (1946).

(29) BRADLEY,W.F.: The structural scheme of attapulgite. The Amer.Mineralogist. 25:405-410 (1940).

(30) BRADLEY,W.F.: Diagnostic criteria for clay minerals. Am. Mineral. 30:704-713 (1945).

(31) BRADLEY,W.F. and R.E.GRIM: Collold properties of layer silicates. Journ,Phys,Chem. 52:1404-1413 (1948).

(32) BRAGG,W.I.: Atomic structure of minerals.

Cornell Univ. Press., New-York 1937.

(33) BRAY,R.H.: Calibrating soll tegts for available potassium. So11 Sc1.Soc. of Amer.Proc. 1:225-231. (1936).

(34) BRINDLEY,G.W.: The structure of clay minerals.

Trans. IV int. Congr. Soll Sc. I:82-86 (1950). 
(35) BRINDLEY,G.W. and K.ROBINSON: The struoture of kaolinite. Mineral. Magaz. 27:242 (1946).

(36) BRINDLEY,G.W. and K.ROBINSON: Randomness in the structures of kaolinitic clay minerals.

Trans. Faraday Soc. $42^{\mathrm{B}}: 198-205$ (1946).

(37) BRINDLEY,G.W. and K.ROBINSON: An X-ray gtudy of some kaolinitic fire c?ays.

Trans. of the British Ceram.Soc. 46:49-59. (1947).

(38) BROWN,A.I. and A.C.CALDWELI: Clay mineral content of the colloldal material extracted from a solodi soll profile,

Soll Sc1.Soc, of Amer.Proc. 11:213-215 (1947).

(39) BUEHRER,T.F.,D.O.KOBINSON and J.M.DEMING: The mineral composition of the colloidal praction of some South-Western soils in relation to field behavicur.

So11 Sc.Soc. of Amer.Proc. 13:157-165 (1948)

(40) BUERGER,M.J.: The rOle of temperature in mineralogy.

Am. Mineral. 33:101-121 (1948).

(41) CAILLERE,S.: I'applioation de l'analyse thermique diff. a l'étude des argiles.

Trans.Int.Cer.Congr.Maastricht 1948.

(42) CAILIERE,S. et S.HENIN: Nouvelles observations our le faratsihite.

C.R.Acad.Sc1. 219:458-459 (1944).

(43) CAILIĖRE,S. et S.HÉNIN: Sur l'origine de quelques anomalies, presentees par les courbes thermiques de certains montmorilionites.

C.R.Acad.Sc1. 219:685-686 (1944).

(44) CAILIERE,S., S.HENIN et M.TURC: Investigations sur I'analyse thermique différentielle des argiles. C.R.Acad.Sc1. 223:383-384 (1946).

(45) CAILIERE,S. et S.HÉNIN: Sur la signification des résultats de l'analyse thermique différentielle. Verre et Sil.Ind. 12 .

(1947). 
(46) CAILLÈRE,S. et S.HENIN : Application de I'analyse thermique à l'étude des argiles des sols. Ann. Agron., 13: 23-73 (1947).

(47) CAILIÈRE,S. et S.HeNIN: Essais de synthése des mineraux argileux.

Verre et Sillcates Ind. Tome 12, No.6 (1947)

(48) CAILIĖRE,S, et S.HENIN: Sur une synthege de I'antigorite à basse temperature.

C.R. de I'Acad, et Sc1. tome 224, 1439-1440 (1947).

(49) CAILIEkRE,S . et S.HENIN: Transformations of minerals of the monitmorillonite family into $10 \mathrm{~A}$ micas. Mineralogical Magazine, 28:606-611 (1949).

(50) CAILLERE,S. et S.HENIN: Experimental formation of chlorites from montmorilionite.

Mineralogical Magazine, 28:612-620 (1949).

(51) CAILLÈRE,S. et S.HÉNIN: Trangformation experimentale du mica en divers types de minéraux argileux par séparation des feuillets.

C.R. de I'Acad.d.Sc1.,tome 228:1741-1742. (1948).

(52) CAIILERE,S, et F.KRAUT: I'analyse thermique differentielle appliquée à l'étude des minerais de fer oolithiques.

Bull.Techn.d.Mines de Fer 4, 1948, 7 pp.

(53) CALDWELI,0.G. and C.E.MARSHALI: A study of some chemical properties of the clay minerals nontronite, attapulgite and saponite.

Miss .Agr.Exp.Sta.Res.Bull., 354, pp.51 (1942)

(54) CHATELIER,M.M.IE: De I'action de la chaleur sur les argiles. Bull. de la Soc. Pranc. de Min. 10:204-211. (1887).

(55) COHN: J. Am.Cer.Soc. 7:359, 475, 548 (1924). Cf. Chem.: Abstr.

(56) COHN: Uber Wurmele1tfuhlgke1t, Würmeausdehnung, spezifische Wurme...von Mineralien und keramischen Massen. Ber.d.deutschen Ker.Ges, 23:245 (1928). 
(57) COLEMAN, N.T.,M.I.JACKSON and A.MEHLICH: Mineral composition of the clay fraction: II of several coastal Plain, Pledmont and Mountain solls of $N$. Carolina.

So1l Sc.Soc. of Amer.Proc., 14:81-85 (1949).

(58) CORRENS,C.W.: Die Tone. Geolog.Rundschau 29:201-218 (1938).

(59) CUTHBERT,F.I.: Clay minerals in Iake Erle sedimenta. Am. Mineral 29:378-388 (1944).

(60) COTHBERT,F.I.: Differential thermal analyses of New Jersej clays.

N.J.Dept.of Conserv.M1x.Geol.Paper 1946, 20 pp.

(61) CUTHBERT,F.I. and R.A.ROWLAND: Differential thermal analygis of some carbonate minerals. Am. Mineral. 32:111-116 (1947).

(62) DAI,P.H.: Methodiek van het kleimineraal-onderzoek II. Chem. Weekbl. 44:123-127 (1948).

(63) DAMOUR,A. et E. SALVETAT: Analyges our un hydrosilicate d'alumine trouvé a Montmorilion (Vienne). Ann.Chim.Phys: 21:376-383 (1847).

(64) DEAN,I.A.: D1fferential thermal analysis of Hawailan soils. Soll Sc1., 63:95-105 (.1947).

(65) DÉRIBÉRÉ,M.: Papiers 1 norganiques.

Papeter1e 69:109-113, 137-139, 141, 171, 173, (1947).

(66) DEUEL,H. and F.HOSTETTLER: Hundert Jahre Ionenaustausch. Experientia, 6:445-456 (1950).

(67) DION,H.G.: Iron oxide removal from clays and its influence on base-exchange properties and $X$-ray diffraction patterns of clays. So11 Sc1., 58:411-424 (1944).

(68) DUUREN,A.J.van: Nederlands-Indische bleekaarden. Meded.No.27 Afd.Handelsmuseum v.h. Kol.Inst. Amsterdam, 81 pp. (1943).

(69) EDELMAN,C.H.: Relationg between the cryatal stmucture of minerale and their base-exchange capacity. Trans of the Third Int.Congr.of Soll Sc1. vol. 3: $97-99$ (1935). 
(70) EDELMAN,C.H.: Moderne inzichten inzake kleimineralen. Landbk.T1jdechr. Jrg. 49:358-377 (1937).

(71) EDELMAN,C.H.: Relations entre les propriétes et la sitructure de quelques minéraux argileux.

Verre et allicates Industriele Tome 12, No, 6, p.1-4 (1947).

(72) BDELMN,C.H.: Over de betrekkingen tussen de eigenschappen en de kristalatructuur van enkele kleimineralen.

Landbk. T1jdachr. 60:221-224 (1948).

(73) EDELMAN,C.H.,F.A.V.BAREN en J.Ch.I.FiViJEE: Mineralogische onderzoekingen aan kleten en kleimineralen $I$. General discussion of the composition of clays... etc.

Meded.Landb.Hogesch. -Wageningen 43,No.4 (1939).

(.74) EDEIMAN,C.H. and J.Ch.I.FAVEJEE: On the cryotal structure of montmorillonite and halloysite.

Zo1techr. 1.Kristal. (1940).

(75) EDELMAN,C.H. and A.C.SCHUFFELEN: On the origin of some clay minerals in soils.

Comptes Rendus du Congres de Pédologie, Montpellier-Algers. p.109-114 (1947).

(76) ENDELI,J.: Zur Kenntn1s des Attapulgits.

Z.Naturforschung 1:646-649 (1946).

(77) ESIN,O.A.,P.V.GEL'D and S.I.POPEL: Redistribution of ions in the thermal dissociation of double salts. Zhur.Priklad.Kh1m. 22:345-360 (1949).

(78) FAOST,G.T.: Thermal analysis of quartz and its use in calibration in thermal analyola siudies.

Am. Mineral 33: 337 (1948).

(79) FAUST,G.T.: Differentation of aragonite from colcite by differential thermal analyala. Sclence 110:402-403 (1949).

(80) FAUST,G.T.: Thermal analysis studies on carbonates.I Aragonite and calcite. Am. Mineral 35:207-224 (1950). 
(81) FAVEJEE,J.Ch.I.: Mineralogische onderzoekingen aan kleien en kleimineralen II Quantitative $\mathrm{X}$-ray analysis of some Dutch soils. Meded:Irandb.Hogeschool-Tageningen. 43, No. 5 (1939).

(82) FAVEJEE,J.Ch.I.: Quantitative rontgenogiraphische Bodenunterouchung.

Z.Rrlotallogr. (A) vol. 101:259-270 (1939).

(83) FAVEJEE,J.Ch.I.: De betekenis van de mineralogische samenstelling voor de indeling en benaming van zware gronden.

Versl.Subcomm. $38^{a}$ Normalisatie Comm. (1943).

(84) FAVEJEE,J.Ch.I.: Vergel1jkend onderzoek van twee IIjnkeramische kleien.

Meded.No.10 v.h. Ker.Inst.T.N.0. 5 pp. (1944).

(85) FAVEJEE,J.Ch.I.: De mineralogioche samenstelling van de kleifractie van Nederlandse grondsoorten. Landbk. T1jdechr. 61:167-171 (1949).

(86) FENNER,C.N.: The stability relations of the silica minerals.

Am.Journ.Sc1. 36:331-384 (1913).

(87) FORSIIND,E.: The clay-water sygtem. I.Crystal structure and water adsorbtion of clay-minerals. Bull. No.11 Swedisch Cement and concrete Research Inst1tute, Stockholm (1948).

(88) FOSHAG,W.F. and A.O.TOODFORD: Bentonite magnesium clay from California.

Am. Mineral. 21:238-251 (1936).

(89) FREDERICKSON,A.F.: Differential thermal curve of oiderite. Am. Mineral. 33:372-375 (1948).

(90) GEILMANN, W.,W.KIEMM and K:MEISEL: Das verhalten des Nontronits bety Erhitzen.

Naturwiss. 20:639-640 (1932).

(91) GERARD HIRNE et Ch.IAMY: Identification des argiles par l'analjae thermique differentielle. Bull.d.Ia Soc.franc. d.céram. 10.26-40 (1951). 
(92) GIBSON,R.E.: The influence of pressure on the high-low invergion of quartz.

Journ.Phys.Chem. 32:1197-1205 (1928).

(93) GIESEKING,J.E.: The clay minerals in solls.

Advances in Agronomy 1: 159-204 (1949).

(94) GORBUNOV,N.J. and SHURIGYNA,E.A.: Heating curves of minerals found in solis and rocks.

Pochvovedenie 1950:367-373.

(95) GRIM,R.E.: Petrography of the fuller's earth deposits, 0Imstead, IIIinols.

Economic Geology, vol.28 No.4:344-363 (1933).

(96) GRIM,R.E.: The properties of clay. Recent Marine Deposits;

a symposium.

Am.Assoc.of Petr.Geologists, Tulsa, Oklahoma. (1939).

(97) GRIM,R.E.: Relation of the composition to the properties of clays.

J.Am.Cer.Soc. 22:141-151 (1939).

(98) GRIM,R.E.: Modern concepts of clay minerals.

J. of Geol. 50:225-275 (1942).

(99) GRIM,R.E.: Differential thermal curves of prepared mixtures of clay minerals.

Am.Mineral. 32:493 (1947).

(100) GRIM,R.E. and W.F.BRADLEY: Investigation of the effect of heat on the clay minerals illite and montmorillonite.

J.Am.Cer.Soc. 23:242 (1940).

(101) GRIM,R.E. and W.F.BRADLEY: Rehydration and dehydration of the clay minerals.

Am.M1neral. 33:50-59 (1948).

(102) GRIY,R.E.,R.H.BRAY and W.F.BRADTEY: Constitution of bond clays and its influence on bonding properties Trans.Am.Founddrymen's Assoc. 7:211 (1936).

(103) GRIM,R.E.,R.H.BRAY and W.F.BRADLEY: The mica in argillaceous sediments.

Am. Mineral. 22:813-829 (1937).

(104) GRIM,R.E. and R.A.BOWIAND: Differential thermal analysis of clay minerals and other hydrous materials. Am.Mineral. 27:746-761; 27:801-818 (1942). 
(105) GRIM,R.E. and R.A.ROWLAND: Differential thermal analysis of clays and shales: a control and prospecting method.

J.Am.Cer.Soc. 27:65-76 (1944).

(106) GRIM,R.E. and F.I.CUTHBERT: Some clay-water properties of certain clay minerals. Journ. of the Ceramic Society 28:90-95 (1945).

(107) GRIMSHAW,R.W.,E.HEATON and A.I.ROBERTS: Constitution of refractory clays II: Thermal analysis methods. Trans.Brit.Ceram.Soc. 44:76-92 (1945).

(108) GRIMSHAW, R.W . A.WESTERMAN and A.I.ROBERTS: Trans.Brit.Cer.Soc. 47:269 (1948).

(109) GRIMSHAW,R.T. and A.I.ROBERTS: Studies on the clay-quartz systems.IV: Extension of the thermal analysis method to quartzite rocks. Gas.Res.Board Publ.41:21-26 (1948).

(110) GRUNER,J.W.: The orystal structure of kaolinite. Zeitschr. Kristallogr. 83:75-88 (1932).

(111) GRUNER,J.W.: The crystal structure of dickite. Zeitschr. Kristallogr. 83:394-404 (1932).

(112) GRUNER,J.T.: The crystal structure of nacrite and a somparison of certain optical properties of the kaolin group with its structure. Zeitschr. Kristallogr. 85:345-354 (1933):

(113) GRUNER,J.T.: Densities and structutal relationship of kaolinites and anauxites. Am. Mineral 22:855-860 (1937).

(114) GRUNER,J.W.: Cristobalite in bentonite. Am. Mineral 25:587-590 (1940).

(115) GRUNER,J.W.: Progress in silicate structures.l Am. Mineral 33:679-691 (1948).

(116) GRUVER,R.M.: Precision method of thermal analysis. J.Am.Cer.Soc. 31:323-328 (1948).

(117) GRUVER,R.M.,E.C.HENRY and H.HEYSTEK: Suppresion of thermal reactions in kaolinite. Am. Mineral 34:869-873 (1949). 
(118) GUTIERREZ RIOS,E.: Deshidratacion y cambio de bases de arclilas en relacion con ou estructura cristaIina y condiciones de formacion.

Ann.Inat.Esp.Edafol. 4:133-147 (1945).

(119) GUTIERREZ RIOS,E. en GONZALEZ GARCIA,F.: Sobre la seria isomorfa montmorillonita-beidelitia.

Ann.Inst.Esp.Edafol. 1:605-621 (1948).

(120) HAMIITON,R.: Standaard dehydratatiecurven en enige toepassingen.

Landbouw 20: 275-282 (1948).

(121) HARDON,H.J. en J.Ch.I.FAVEJEE: Mineralogische onderzoekingen aan kleien en kleimineralen III. Qualitative $X$-ray analysis of the clay fraction of the principal soll types of Java. Meded.Landb.Hogeschool 43: No.6 (1939).

(122) HARMAN,C.B. and C.T.PARMELEE: Fundamental properties of raw clays influencing their use.

Journ. of the Am.Ceramic Society vol. 28: $110-118$ (1945).

(123) HAUSER,E.A.,D.S.Ie BEAU andP.P.PEVEAR: The surface structure and composition of colloidal siliceous matter. Journ.Phys.Coll.Chem. 55:68-79 (1951).

(124) HAOSER,J.: Die nicht-austauschbare Festlegung des Kalis im Boden.

Disg. Wageningen 1941.

(125) HENDRICKS,S.B.: Concerning the crystal structure of kaolinite $\mathrm{Al}_{2} \mathrm{O}_{3} \cdot 2 \mathrm{SiO}_{2} \cdot \underset{2}{2} \mathrm{H}_{2} \mathrm{O}$ and the composition of anaurite.

Zeitschr.f.Kristall. 95:247-252 (1936).

(126) HENDRICKS,S.B.: Crystal structure of the clay mineral hydrates.

Nature 142:38 (1938).

(127) HENDRICKS,S.B.: The crystal.structure of talc and pyrophylite.

Zeitschr.1.Kristall. 99:264-274-(1938). 
(128) HENDRICKS,S.B.: The oryatal structure of nacrite $\mathrm{Al}_{2} \mathrm{O}_{3}$. $2 \mathrm{~S}_{2} \cdot 2 \mathrm{H}_{2} \mathrm{O}$ and the polymorphim of the kaolin minerals.

Zeitachr.f.Kriatall. 100:509-518 (1938).

(129) HENDRICKS,S.B.: The crystal atructure of the clay minerals dickite, halloysite and hydrated halloysite.

The Amer.Mineral. 23: 295-301 (1938).

(130) HENDRICKS,S.B.: Random structures of layer mineralo as illustrated by cronstedtite ( $2 \mathrm{FeO}^{-\mathrm{Fe}_{2} \mathrm{O}_{3}}$. $\mathrm{SiO}_{2} \cdot 2 \mathrm{H}_{2} \mathrm{O}$ ) Possible iron content of kaolin. Amer. Mineral. 24:529-539 (1939).

(131) HENDRICKS, S.B.: Base-exchange of the mineral montmorillonite for organic cations and its dependence upon adsorbtion due to van der Taals forces. Journ.Phys.Chem., 45:65-81 (1941).

(132) HENDRICKS,S.B.: Lattice structure of clay minerals and some properties of clay. Journ. of Geology 50: 276-290 (1942).

(133) HENDRICKS,S.B.: Base exchange of crystalline silicates. Ind. and Eng.Chem. 37:625-639 (1945).

(134) HENDRICKS,S.B. and I.T.ALEXANDER: Crystal structure of vermiculites and mixed vermiculites-chlorites.

Am. Mineral. 23:851-862 (1938).

(135) HENDRICKS,S.B. and I.T.ALEXANDER: Minerals, present in soil colloids I: Descriptions and methods for identification. Soil Sci., 48: 257-271 (1939).

(136) HENDRICKS,S.B. and I.T.ALEXANDER: Semiquantitative estimation of montmorillonite in olaye. Soll Sci.Soc. of Amer.Proc. 5: 95-99 (1940).

(137) HENDRICKS,S.B. and T.H.FRY: The results of X-ray and mioroscopical examinations of soll collolds. Soil Sc1., 29:457 (1930).

(138) HENDRICKS,S.B. and M.E.JEFFERSON: Structure of kaolin and talc pyrophyllite hydrates and their bearing on water sorption by the clays.

Am. Mineral. 23: 863-875 (1938). 
(139) HENDBICKS,S.B., R.A.NELSON and I.T.ALEXANDER: Hydration mechanism of the clay mineral montmorillonite, eaturated with varlous cations. J.Am.Chem.Soc. 62:1457-1464 (1940).

(140) HENDRICKS, S.B. and C.S.ROSS: Chemical Composition and genesis of glauconite and celadonite. The Amer.Mineral. 26:683-708 (1941).

(141) HENDRICKS,S.B.,S.S.GOIDRICH and R.A.NELSON: On a portable differential thermal outfit. Econ. Geol. 41 : 41 (1946).

(142) HODGMAN,Ch.D.: Handbook of phys1cs and chemistry. 30th ed.Chem. Rubber Publ.Co. 1948.

(143) HOFMANN, V.,K.ENDELU and D.WIIM: Kristallstruktur und Quellung von Montmorilionit. Zeitschr.Krist.(A) 86:340-348 (1933).

(144) HOFANN, V.,K.ENDELI and D.WILM: Röntgenographische und Kolloidchemische Untersuchungen uber Ton. Ze1techr.f.Angew.Chemle 47:539-547 (1934).

(145) HOFMANN, V. and W.BIIRE: Uber die interkristalline Quellung und das Basenaustauschrermbgen des Montmorilionits.

Kolloid Zeitschr. 77:238-251 (1936).

(146) HOFuNN, V.,A.JAKOB and H.IOOFMANN: Untersuchung der TonPraktion der Boden mit dem Elektronen-Mirkoskop.

Bodenk.u.Pfl.ern. 25(70):257-271 (1941).

(146a) HOYOS de CASTRO,A.,F.GONZÁLEZ GARCIA and J.MARTIN VIVAIDI: Acerca de la constitucion $\mathrm{y}$ propriedades de una vermiculita de Beni Buxera.

An.de la Real Soc.Esp.d.Fys. y Quim. 46: 715-726 (1950).

(147) HOULDWORTH,H.S. and J.T.COBB: The behaviour of fireclays etc. on heating. Tr.Cer.Soc. 22: 111,345 (1923)

(148) HOULDSWORTH;H.S. and J.T.COBB:

Trans. Cer. Soc. 23:284 (1924). 
(149) HUMBERT,R.P. and C.E.MARghuTr: Mineralogical and chemical atudies of soll formation from acid and basic igneous rocks in Missouri.

Miss.Agr.Exp.Sta.Reg.Bull. 359 pp.60 (1343).

(150) HfTTIG,G.F. und HEINZ KAPPEI: The kinetics of thermal decomposition of calcitum carbonte.

Angew.Chem. 53:57-j9 (1940).

(151) HUTTIG,G.F. und HEIGA. HEINZ: The rate deoompositiun of calcium carbonate and the effect of foreign gases on it.

Zeitschr.anorg.Chem. 255:223-237 (1948).

(152) INSLEY,H. and R.H.EWELL: Thermal behaviour of kaolin minerals.

Nat. Bureau of Standards, J.Res. 14:615-627. (1935).

(153) JACKSON,M.I. and E.TRUOG: Influence of grinding soil minerals to near molecular size on their solubility and base-exchange properties. Soll Sc1.Soc.of Amer.Proc. 5:136-143 (1940).

(154) JACKSON,M.L.et al.: Fundamental generalizationg on the weathering sequence of clay minerals in soils and sediments.

J .Phys .Chem. 52:1237-1260 (1948).

(155) JACOB,A.: Ist die Zusammensetzung der Tonfraktion des Bodens ststisch oder dynamisch auf zu fassen? So11 Research 7:250-262 (.1940).

(156) JACOB,A., V.HOFMANN und E.MAEGDEFRAU: Chemioche und röntgenographische Untersuchungen uber die mineraIische Sorption substanz im Boden. Bethefte Angew.Chem. No.21:11-19 (1935).

(157) JACOB,MAX: Heat transfer. New-York 1949. f

(158) JEFFRIES,Ch.D.: A quantitative approach to the study of the thermal characteristica of clays. Soll Sc1.Soc.of Amer.Proc. 9:86-91.(1944).

(159) JOFPE,J.S.: Pedology. New Brunowick 2 ed. (1949).

(160) JUNG,H.: Zur Frage der chemisch-physikalischen Vorgänge beim Entwä日sern und Wiederwä日sern von Kaolinkristallen.

Chem.d.Erde 7:113-120 (1932). 
(161) KELIEY,W.P.: Modeirn clay research in relation to agriculture.

Journ. of Geology. vol. 50:307-319 (1942).

(162) KELLEY,W.P.: Cat1on exchange in so1la. New-York 1948.

(163) KRLIY,W.P.,W.H.DORE and S.M.BROWN: The nature of the baseexchange material of bentonite, soils and zeolites as revealed by chemlcal investigation and $X$-ray analyaia.

So11 Sc1. 31:25-55 (1931).

(164) KELIFY,W.P. and B.JENNY: The relation of crystal structure to base exchange and its bearing to base ezchange in soils.

So11 Sc1. 41:367-382 (1936).

(165) LELIFY,W.P.,H.JENNY and S.M.BROWN: Hydration of minerals and $\mathrm{soll}$ colloids in relation to crystal etructure.

So1l Sc1. 41:259-274 (1936).

(166) KELLE,W.P. and J.B.PAGE: Criteria for the Identification of the constituents of soll colloids.

Soll Sc1.Soc.of Amer.Proc. 7:175-181 (1942).

(167) KELIEY,W.P., A.O.WOODFORD,W.H.DORE and S.M.BROWN: Comperative study of the colloids of a Cecil and a Susquehanna soll profile.

So11 Sc1. 47:175-193 (1939).

(168) KGRR,P.F.: Bentonite from Ventura, California. Econ.Geol. 26:153-168 (1931).

(169) KGRR,P.F.: Montmorillonite or smectite as/constituents of fuller's earth and bentonite. Am.Mineral. 17:192-198 (1932).

(170) KERR,P.F.\& Attapulgus clay. Am.uineral. 22:534 (1937).

(171) KGBR,P.F.: A decade of research on the nature of clay. Journ.Am.Ceram.Soc. 21:267-283 (1938).

(172) KGRR,P.F. and P.K.HAMIITON: Glossary of clay mineral names.

American Petroleum Inst., Prel.Rep.No.1 (1949). 


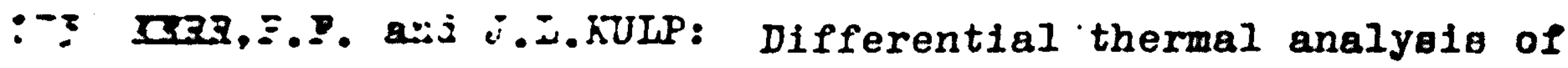
siderite.

Am.Mineral. 3i்: 678-680 (1947).

(174) KGRR,P.F. and J.I.KULP:- Multiple differential thermal analysia.

Am.uineral . 33:387-419 (1948).

.(175) KRONIG,e.a.: Leerboek der Natuurkunde. Amsterdam, 1947.

(175a) KRUYT,H.R.: Inleiding tot de physische ocheikunde. Amsterdam 1948.

(176) KULP,J.I. and P.F.KGRR: inltiple thermal analygis. Science 105:413 (1947).

(177) KULP,J.I. and P.F.KERR: Improved differential thermal analyois apparatus. Am.Mineral. 34:839-845 (1949).

(178) KULP,J.I.,H.D.WRIGHT and R.J.HOIMES: Thermal study of rhodochrosite. Am.Mineral. 34:195-219 (1948).

(179) KURNAKOFF,S.N. and V.V.TSCHERNYCK: Mem.d.1.Soc. Russe de M1n. 57:62 (1928).

(180) IAANGE,N.A.: Handbook of chemiatry. $6^{\text {th }}$ ed. 1946, Ohio.

(181) IAAPPARENT,J.de: Sur un constituent des terres a foulon. C.R.de I'Acad.Sc1.Franc. 201:481-482 (1935).

(182) ILAPPARENT,J.de: A propos de l'attapul gite. Zeitschr.1.Kristall. 97:237 (1937).

(183) IAPPARENT,J.de: Formules structurales et classieication des argiles. Zeitschr.f.Kriotall. 98:233 (1938).

(184) IARSEN,E.S. and E.T.WHGRRY: Beidelite, a new mineral name. Journ. Wash. Acad.Sci., 15:465-466 (1925).

(185) IIARSON,W.E.,W.H.ALTANAY and H.F.RHOADES: Characteriatica of the clay eraction of various horlzons of scott gilt loam and Pawnee silt loam. Soll Sc1.Soc. of Amer.Proc. 11:443-447 (1946)

(186) IEENHEER,I.de: Les propriétés sorptives des sols et leur interprétation minéralogique, arec application aux sols argileux des Polders maring. Bull.de la Soc.Belge de Géol.Tome 57:299-320 (1948). 
(187) TEENHEER, I. des

MIneralogische ondarzoekingen van kleimineraIen. Yed.Iandb.hogeschool en Opz . stat.Gent.4: $(.939)$.

(188) IONGCHNRON,H.: Sur les characterigtiques des palygorgkites.

C:R.de I'Acad.Sci.Franc. 204:55-56 (1937).

(189) IONGCHAMBON,H.: Ies courbes de déshydration des minéraux. Bull.de la Soc.Franc.d.Min. 59: 145-161 (1945).

(190) MACEWAN,D.M.C.: The identification and estimation of the montmorilionite group of minerals, with special refeṛence to soil clays.

Journ.of the soc. of Chem.Ind. 65:298$304(1946)$.

(191) MACKENZIE,R.C.: Differential thermal analysis of clay mineralo.

Trans.Fourth.Int.Congr.Soll Sci., II:55$59(1950)$.

(191ä) McADAMS,W.H.: Heat transmission. New-York, 1933.

(192) MCCONNELI,D.: The crystal chemistry of montmorillonite. Am.Mineral. 35:166-172 (1950).

(193) McGEE: The heat required to fire ceramic bodies. J.Am.Cer.Soc. 9:206-247 (1926) 10:352 (1927).

(194) MAEGDEFRAU,E.: Die Gruppe der glimmerartigen Tonmineralien. Sprechsaal 1941.

(195) MAEGDEFRAU,E. und V.HOFMANN: Die Kristallstruktur des Montmorilionits. Ze1tschr.Kristall. (A) 98:299-323 (1937 b).

(196) MALIARD,F.E.: Sur le bravaisite: substance minérale nouvelle. Bull.Soc.Franc. de Min. 1:5-8 (1878).

(197) MANLY,R.I.: The differential thermal analysis of certain phosphates.

Am.Mineral. 35:108-115 (1950).

(198) MAREI,H.W.v.d.: Mineralogical composition of a heath podzol profile.

So11 Sc1., 67:193-208 (1949). 
(199) KAREL,H.W.V.d.: Chemisch-mineralogisch grondonderzoek. T.N.O. Nieuws $4: 403-411$ (1949).

(200) MAREI,H.W.V.d.: The mineralogical composition of the clay $(<2 \mu)$. separate of the Dutch soils and their cationic exchange capacity.

Trans.IV int.Confr.So11 Sc1.II:92-94 (1950).

(201) MARSHAII,C.E.: Iayer lattices and the base-exchange of cisys.

Zeitschr.f.Kristall. 91:433-449 (1935).

(202) MARSHALI,C.E.: The colloidal properties of clayo as related to their orystal structure. Journ.Phys .Chem. 41: 935-942 (1937).

(203). MARSHALI,C.E.: Ionization of calcium from so1l collo1da and its bearing on soll-plant relationships.

So11 Sc1., 65:57-68 (1948).

(204) MARshaII,C.E.: The colloid chemigtry of the silicate minerals.

New-York 1949, pp.195 (1949).

(205) MARSHALL,C.E. and C.A.KRINBILL: The clays as collo1dal electrolytes.

J.of Phys.Chem. 46:1077-1090 (1942).

(206) MATTYASOVKY-ZSOINAY, I.: Illite, montmorillonite, halloysite and volcanic ash as whiteware body ingredients.

Journ. of the Am.Ceram.Soc. 29:254-260 (1946).

(207) MEHLICH,A. and W.E.COLWELI: Influence of nature of soil collolds and degree of base saturation on growth and nutrient uptake by cotton and soybeans .

Soll Sc1.Soc. of Amer.Proc. 8:179-184 (1943).

(208) MEHMEL,M.: Uber die Struktur von Halloyait und Metahalloysit.

Zeitschr.f.Kristall. 90:35- 43 (1935).

(209) MERING,J .: Sur l'hydratation du montmorillonite.

Trans . Farad.Soc.42B: 205-219 (1946). 
(210) MERVEILIE,J. and A.BOUREIIIE: Identiflcation des argiles óramique par la thermobalance.

Bull.de Ia Soc.Franc.d.Cer.No.7:18-27 (1950).

(211) MEULEN,J.B.V.d.: The relation between the phenomenon of cation exchange with ollica-alumina compleres and their crystal structure.

Rec. des Trav.Chim. 54:107-110 (1935).

(212) MUIDER,E.M.J.: Iets over de temperatuurregeling van ovens ten behoeve van de thermische analyse. C.I.M.O., 1949, $10 \mathrm{pp}$.

(213) MUNIER,P. and J.MENERET: Apercu d'ensemble sur les argiles-céramiques II: Identification des argiles céramiques par la dilatométrie en cru. Bull.de la Soc.Franc.d.Cér.No.7:6-17 (1950).

(214) MURRAY,P. and J.WHITE: Kinetics of the thermal dehydration of clays.

Trans.Brit.Cer.Soc. 48: 187-206 (1949).

(215) NAGELSCHMTD,G.: The identification of minerals in soil colio1ds.

Journ.Agr.Sc1. 29:477-501 (1939).

(216) NAGEISCHMIDT,G.: The mineralogy of soil colloids. Techn.Comm.No.42.Imp.Bur.So1l Sci.Harpenden, Herts Eng. 1944. pp.33 (1944).

( $216 a)$ NERUST

(217) NOIL, W.: Zur Kenntnis des Nontronits. Chemle der Erde. 5:375-384 (1930).

(218) TORIN,R.: The decomposition products of kaolinite. Geol.FBren F6rk. 66:15-18 (1944).

(219) NORTON,F.H.: Critical study of the differential thermal method for the identification of clay materials. J.A.Cer.Soc. 22:54-63 (1939).

(220) HORTON,F.H.: Analysis of high alumina clays by the thermal method.

J.A.Cer.Soc. 23: 281-282 (1940).

(221) NORTON,B.H.8 Hydrothermal formation of olay minerals in the laboratory, part.II.

The Amer.Mineral. 26:1-17 (1941). 
12:2: MOBTOA,P.H.: Application of modern clay research in ceramics.

$$
\text { J.of Geology 50:320-330 (1942). }
$$

(223) NUTTING,P.G.: The bleaching clays. CIrc.No.3 UnIted States Geol.Survey (1933).

(224) NOTTING,P.G.: Some standard thermal dehydration curves of mineralo.

U.S.Geol.Surv.Prof.Paper 197E: 197-217 (1943).

(225) ORCEI,J.: Reoherches our la composition des chlorites. These Paris 1927. Bull.Soc.Franc.d.Min. 50: (1927).

(226) ORCBI,J.8. I'emploi de I'analyse thermique différentielle dans la détermination des constituants des argiles latérites et des bauxites. VII Congr.int.d.uines Géol.appl. 1: 357-373. (1935).

(227) ORCEL,J and S.CAILIERE: I'analyse thermique differentielle des argiles et des montmorillonites. C.R.Acad.Sc1. 197:774 (1933).

(228) PAGE,J.B.: Differential thermal analyois of montmorillonite.

So11 Sci. 56:273-283 (1943).

(229) PAGE,J.B. and I.D.BAVER: Ionic size in relation to fixation of cations by colloidal clay. Soll Sci.Soc.of Amer.Proc. 4:150-155 (1939).

(230) PARUELEE,C.T.: Clays and some other ceramic materialo. Edward Bros.Ann.Arbor.Mich. (1939).

(231) PAULING,I.: The nature of the chemical bond and the structure of molecules and crystals. Cornell Univ.Press. New-York, pp.450 (1948).

(232) PAVIOVITCH,S.: The action of heat upon some natural oxy-. des of manganese. C.R.Acad.Sc1. 200:71-73 (1935).

(233) PERKINS,A.T.: Reactions of bentonite as influenced by adsorbed cations and grinding.

Soil Sc. of Am.Proc. 14:93-9 (1949). 
(234) PERKINS,A.T. and H.H.KING: Phosphate Iixation by soil minerals: mioa and related groups.

Soll Sc1.Soc.of Amer.Proc. 8:154-158 (1943).

(235) PETERSON,J.B.: The effect of montmorillonitic and kaolinitic clajs on the formation of platy structures.

So11 Sci.Soc. of Amer.Proc. 2:37-48 (1944).

(236) PETERSON,J.B.8 Relation of parent material and environment to the clay minerals in Iowa soils. So11 Science 61:465-475 (1946).

(237) PIETERS,H.A.J.: BIjdrage tot de kennis der dehydratatie van het kaolien. Diss. Delft, 1928.

(238) REICHE,P.: A survey of weathering processes and products. Oniv. of New-Mexico Publ. in Geol. 1:1-87 (1945).

(239) ROBERTS,A.I.: Constitution of refractory clays.I.: Introduction.

Trans.Br1t.Ceram.Soc. 44:69-75 (1945).

(240) ROBORGH,R.H.J.: A study on the nature of clay. Dias. Nageningen, 1935.

(241) ROSS,C.S.: Minerals and mineral relationships of the clay mineralo.

Journ, of the Amer.Ceram.Soc. 28: 173-183 (1945).

(242) BOSS,C.S and S.B.HENDRICKS: Clay minerals of the montmorllIonite group: their mineral and chemical relationships and the factors controlling baseexchange.

Soll Sc1.Soc. of Amer.Proc. 6:58-62 (1941).

(243) ROSS,C.S. and S.B.HENDRICKS: Minerals of the montmorillonite group; Their origin and relation to" soils and clajs.

U.S.Geol.Surv. Prof.Faper 205-B: 23-79 (1945).

(244) ROSS,C.S. and P.F JaRR: Dickite, a kaolin mineral. Am.Mineral. 15:34-39 (1930).

(245) ROSS, C.S. and P.F.KKRR: The kaolin minerals. U.S.Geol.Surv.Prof.Papers. 165 (1930). 
(246) ROSS,C.S. and P.F.KFRR: The clay minerals and their Identity. Journ. of Sed.Petr. 1:55-65 (1931).

(247) ROSS,C.S. and P.F.KERR: Halloysite and allophane. U.S.Geol.Surv.Prof.Papers. 185-G (1934).

(248) ROSS,C.S. and E.V.SHANNON: The minerals of bentonite and related clays and their physical properties. Journ. of the Am.Ceram.Soc. 2:77-96 (1926).

(249) ROWLAND,R.A. and E.C.JONAS: Variations in the different1al thermal analysis curves of siderite. Am.Mineral. 34:550-558 (1948).

(250) RUESS,G.L.: Die Struktur de日 Halloysits. Monatshefte 76:168-173 (1946).

(251) ROSSELI,M.B. and J.I.HADDOCK, The identifioation of the clay minerals in five Iowa soils by the thermal method. So11.Sci.Soc. of Amer.Proc. 5:90-95 (1940).

(252) RIJKEN,A.J. and J.Ch.I.FAVEJEE: Over het ontataan van het terra sigillata-laagje (voorl. meded.). Chem. Weekbl. deel 38, No.20:263-264 (1941).

(253) SAONDERS and GRIEDROYE: Differential thermal analyals in controlled atmosphere. Trans.Brit.Ceram.Soc. 49:365-374 (1950).

(254) SCHAFER,G.M. and M.B.RUSSELI: The thermal method as a quantitative measure of clay mineral content. Soil Sc1. 53: 353-364 (1942).

(255) SCHEFFER, F. und P.SCHACHTSCHABEL: Feinbau und Sorption der Bodenkolloide. Beitrage zur Agrarwigaenghaft 4:11-20 (1948).

(256) SCHUYLENBORGH,J.V.: The electrokinetic behaviour of the sesquioxide-hydrates and its bearing on the genesis of clay minerals.

Trans.IV int.Congr.Soil Sc1.I:89-92 (1950).

(257) SCHUYIENBORGH,J.V. and A.M.H.SANGER: The electrokinetic behaviour: of Iron- and aluminium hydroxides and -oxides.

Rec.d.Trav.Chim.Pays Bar 68:999-1010 (1949). 
(258) SCHUILENBORGH,J.V. and A.M.H.SÄNGER: On the origin of clay minerals in the soll.

Lanbk.Tijdachr. 62:347-358 (1950).

(259) SCHUYLENBORGH,J.V. and P.I.ARENS: The electrokinetic behaviour of freshly prepared $\alpha$ - and $\gamma-\mathrm{FeOOH}$. Rec.d.Trav.Chim.Pays Bas 69:1559-1565 (1950).

(260) SCHUFFELEN,A.C.: Over de interpretatie van de resultaten van grondonderzoek. Meded.Ianb.hogeschool en de Opzoekingsstations. Gent. 13: 169 (1948).

(261) SEDLETSKII,I.D.: Soll collotdal minerals of the aluminium hydroxide group.

C.R. (Doklady) de I'Acad.d.Sci. de I'URSS 19: 721-724 (1938).

(262) SEDLETSKII,I.D.: Genesis of montmorillonite and kaolinite and conditions of their joint occurrence in the colloids of soils and clays. C.R.Doklady Acad.Sci.URSS 22:510 514 (1939).

(263) SEDLETSKII,I.D.: X-ray studies of soils (Russian) Moskou (1939).

(264) SEDIETSKII,I.D.: Calcium montmorillonite in saline soils. Comptes Rendus (Doklady) de I'Acad. de Sciences de I'U.R.S.S. 26:154-155 (1940).

(265) SEDLETSKII,I.D.: On the principles of classification of argillaceous sediments.

C.R.Doklady de I'Acad.d.Sci.de I'U.R.S.S. 26: 240243 (1940).

(266) SEDLETSKII,I.D.: ColloId-dispersold mineralogy (Russ.). Acad.of Sci. U.R.S.S. Moskou-Leningrad. 144 pp. (1945).

(267) SEDLETSKII,I.D.and S.YUSSUPOVA: Mineralogical composition of clays and their phyoical and chemical propertiea.

C.R. (Doklady) de L'Acad.d.Sci.de I'U.R.S.S. 26: 244-246 (1940).

(268) SIEFERT,A.C. and E.C.HENRY: The effect of exchangeable cations on hydrophylic nature of kaolin and bentonite.

Journ. of the Amer.Ceram.Soc. 30:37-48 (1947). 
(269) SINGER,F.: Super duty silica bricks.

Iron and Coal trades Rev. 67:1948.

(269a) SKITH, T.: The thermal conductivity of dry soil.

Soil Sc1. 53453-460 (1942).

(270) SPEIL,S.: Application of thermal analygis to clays and aluminious minerals.

U.S.Bur. of Mines.Rept.Inv. 3764, 36 pp. (1944).

(271) SPEIL,S.,I.H.BERKELHAMER,J.PASK and B.DAVIES: Different1al thermal analysis. Its application to clays and other aluminous materials. U.S.Bur. of Kines, Techn.Paper 664, 81 pp. (1945).

(272) SPEK, J.van der: Het 1jzer in grond en bodem. Chem. Weekbl. 44:493-498, 505-511 (1948).

(273) SOSMAN,R.B.: The properties of silica. New-York 856 pp. 1927.

(274) STRINGHAM, B. and A.TAYLOR: Nontronite at Bingham, Utah. Am.Mineral. 35:1060-1066 (1950).

(275) URASOV: Z. Anorg. Ch. 154:169 (1926).

(276) VOLD,M.J.: Differential thermal analyaia. Analytical Chem. 21:683-688 (1949).

(277) VOLK,G.T.: The nature of potash fixation in s01ls. Soil Sci. 45:263-276 (1938).

(278) TALKER: Mineral Magazine 1949, 1950.

(279) WALKER,G.F. and A.MIINE: Hydration of vermiculite saturated with various cations.

Trans.IV int.Congr.So1I Sc. II: 62-67 (1950).

(280) WALIACH,R.: I'analyse thermique des argiles. C.R.Acad.d.Sc1. 158:48-49 (1913).

(281) WHERRY,E.T.,C.S.ROSS and P.F.KERR: Progress in the atudy of the clay minerals. Collo1d Sympossium Annual. 1:191-193 (1929).

(282) WINCHELL, A.N.: Montmorillonite.

The Amer.Mineral. 30:510-518 (1945). 
(283) WIT,C.T.de and P.I.ARENS: Molsture content and density of some clay minerals and some remarks on the hydration pattern of clay.

Trans.IV int.Congr.So1i Sc1.II:59-62 (1950).

(284) WOHIIN,R.: Silikat Ze1techr: 12:225 (1913).

(285) YURGANOV, V.V. and M.V.zUSuarovICK: Influence of high temperature on Prosyanja kaolin (Ruseian).

Trans.Cer.Res.Ingt. (Moscow) 1929 No. 21:28-55 (1929).

(286) ZATADZKI,M.J.: The action of gaseous acidic oxides on solid metal oxydes. The decomposition of carbonates, wleates and sulfites.

Festkr.J.Arvid.Hedvall 1948:611-634.

(287) ZAWADZKI,M.J. and W.SZAMBORSKA: Kinetics of the decompogition of zinc carbonate.

Bull.intern.Acad.Polon.Sci., Clagse Sci.math. nat.Ber.A: 27-31 (1940-1946).

(288) ZIMMaRmar,J.F.: Diffusion and activation control in heterogeneous reactions.

J.Phys.and Coll.Chem. 53:562-569 (1949).

$$
=====
$$

